\title{
Dimeric Matrine-type Alkaloids from the Roots of Sophora flavescens and Their Anti-hepatitis B Virus Activities
}

Yu-Bo Zhang, ${ }^{\dagger}$ Li-Qin Zhan, ${ }^{\dagger}$ Guo-Qiang Li, ${ }^{\dagger}$ Feng Wang, ${ }^{\star}$ Ying Wang, ${ }^{\dagger}$ Yao-Lan Li, ${ }^{\dagger \dagger}$ Wen-Cai Ye, $*^{\dagger}$ Guo-Cai Wang* ${ }^{\dagger}$

'Institute of Traditional Chinese Medicine \& Natural Products, College of Pharmacy, Jinan University, Guangzhou 510632, People's Republic of China

Institute of Genomic Medicine, College of Pharmacy, Jinan University, Guangzhou 510632, People’s Republic of China

\section{Corresponding Authors}

Emails: twangguocai@jnu.edu.cn (G-C Wang); chywc@aliyun.com (W-C Ye); tliyl@jnu.edu.cn (Y-L Li). 


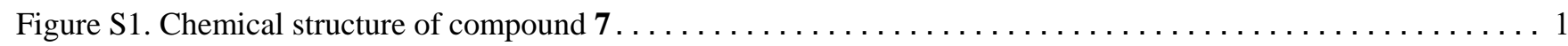

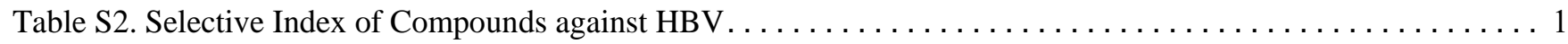

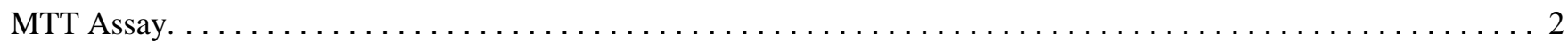

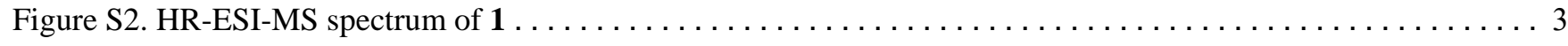

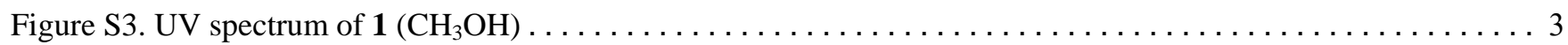

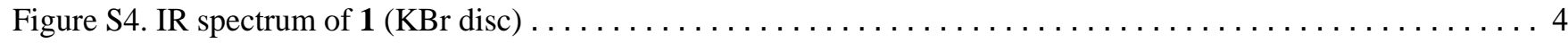

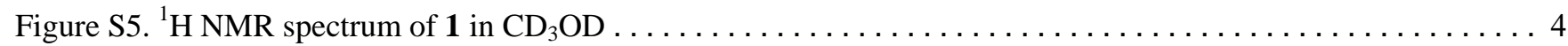

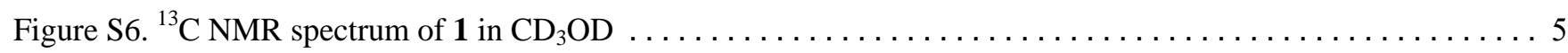

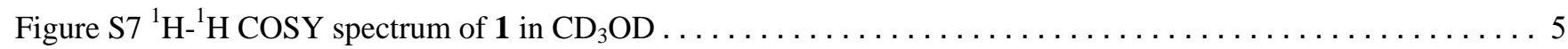

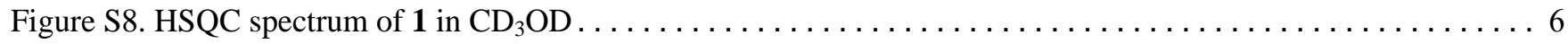

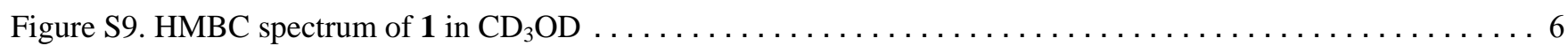

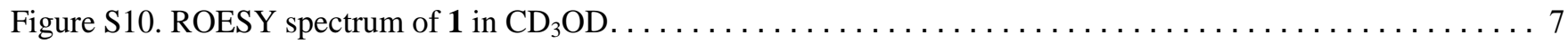

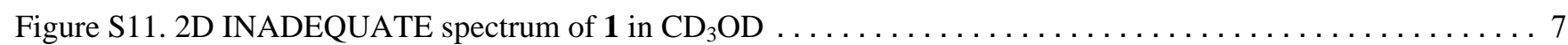

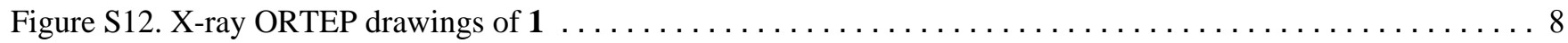

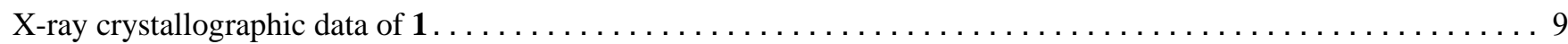

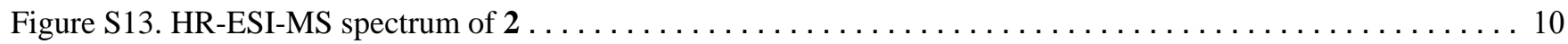

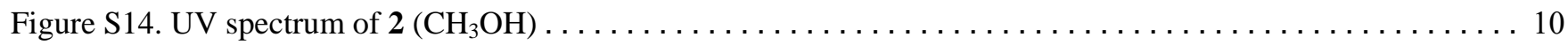

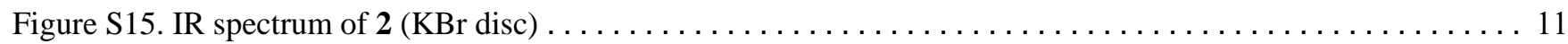

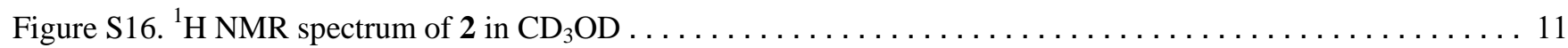

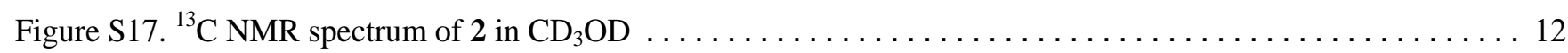

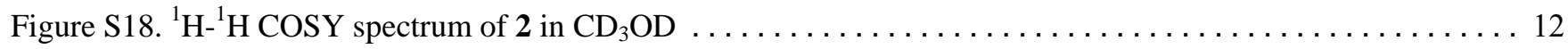

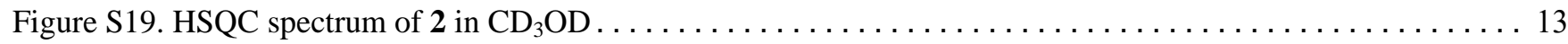

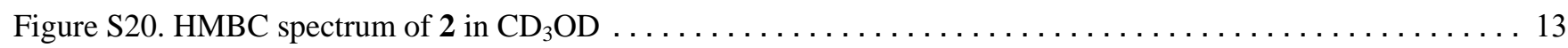

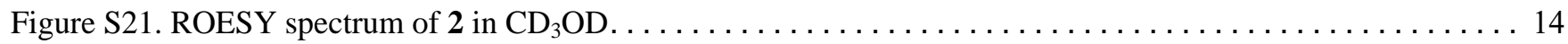

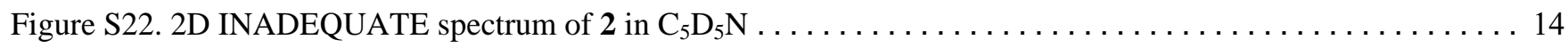

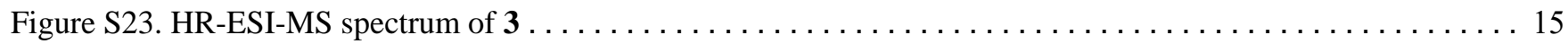

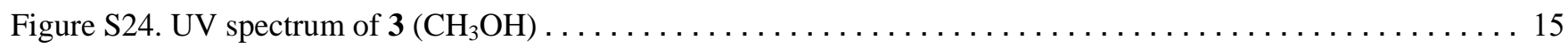

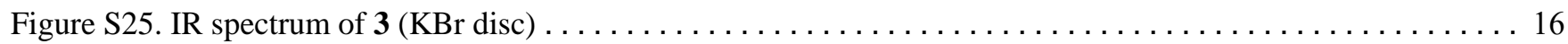

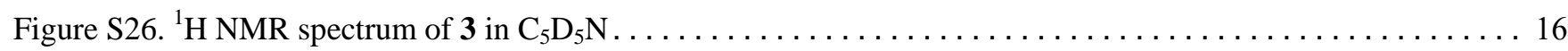

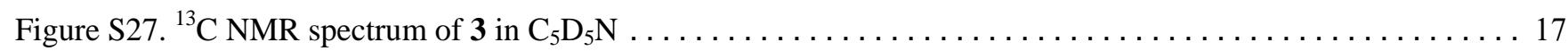

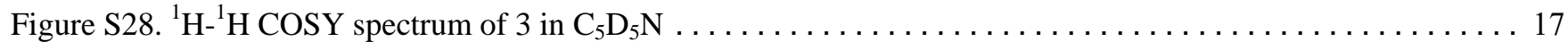

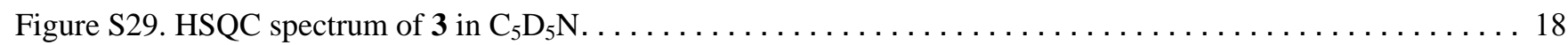

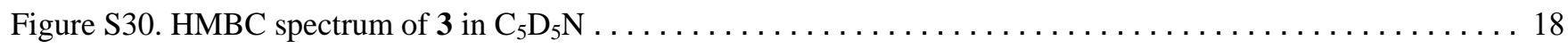

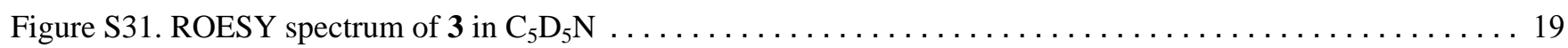

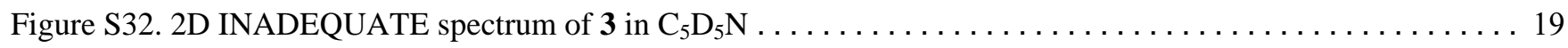

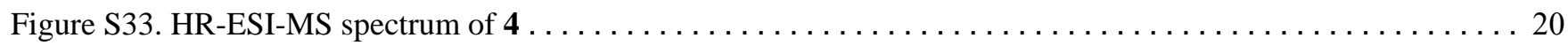

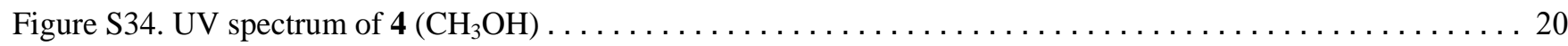

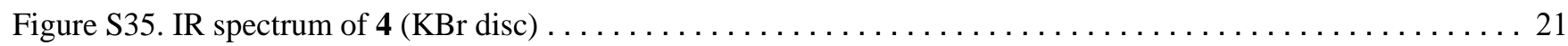

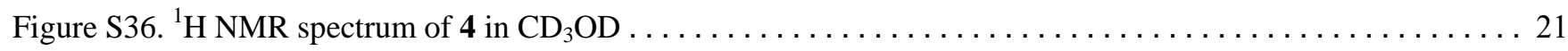

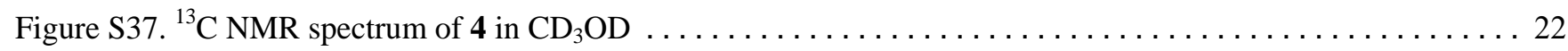




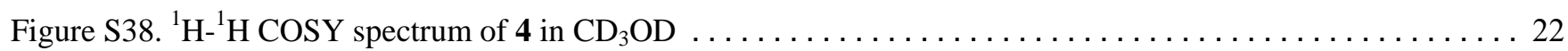

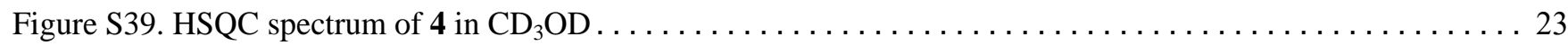

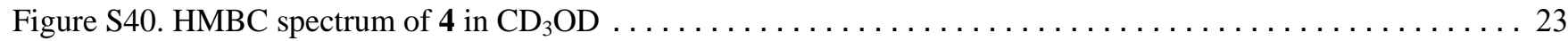

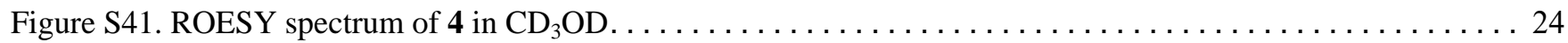

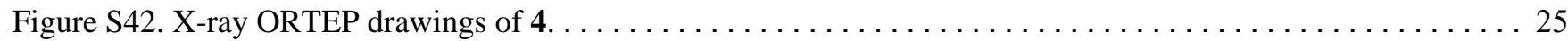

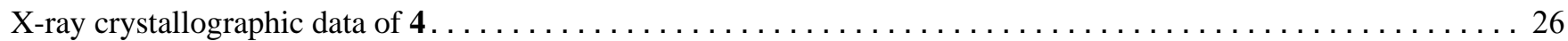

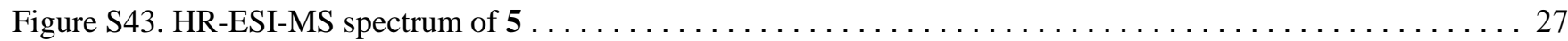

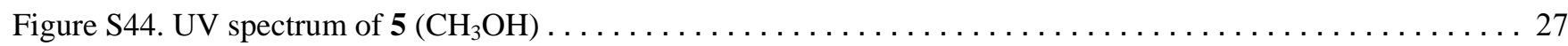

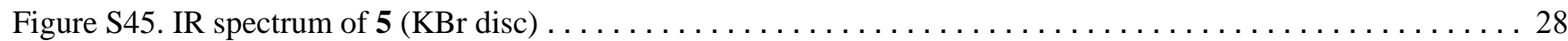

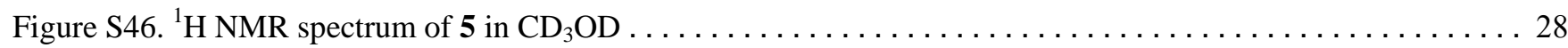

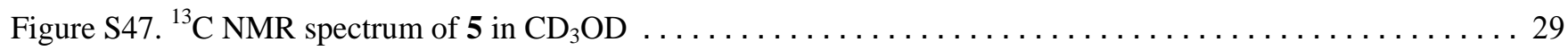

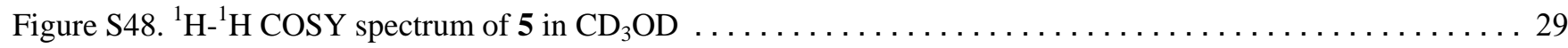

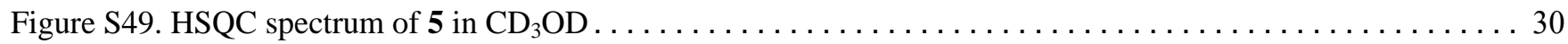

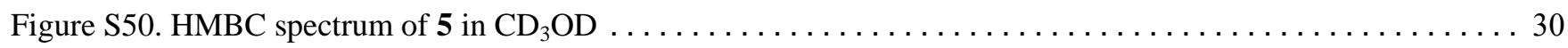

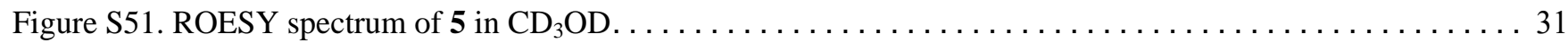

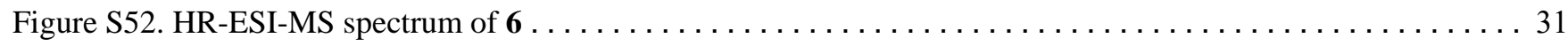

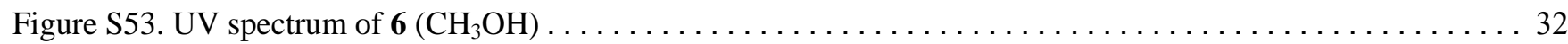

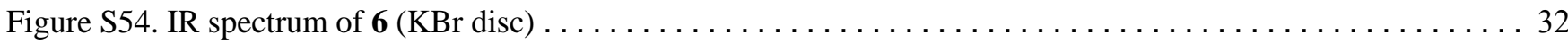

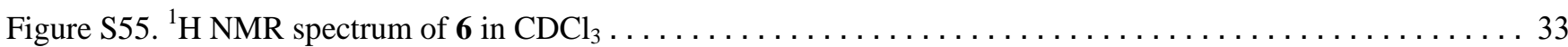

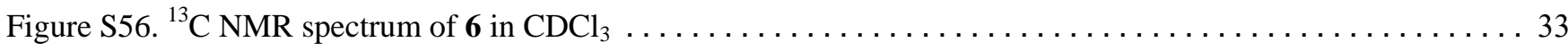

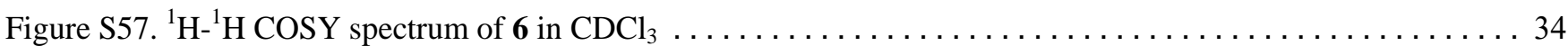

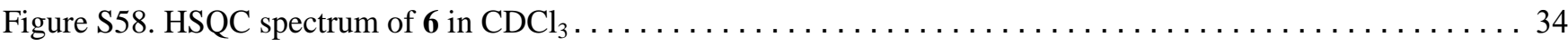

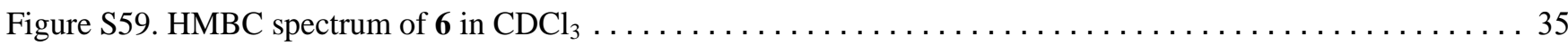

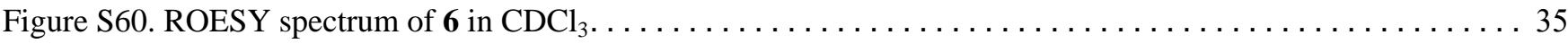

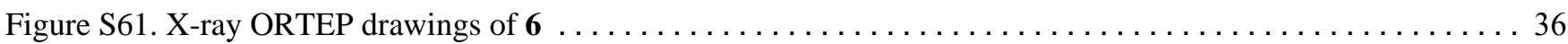

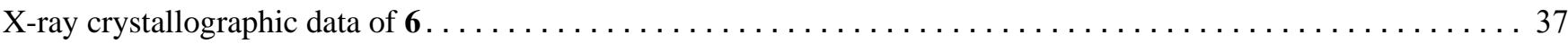

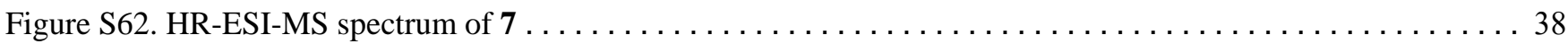

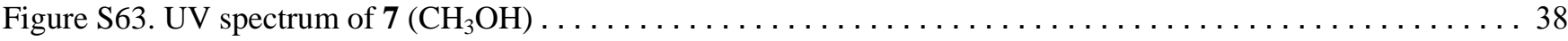

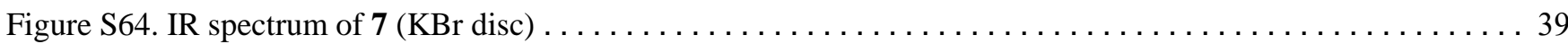

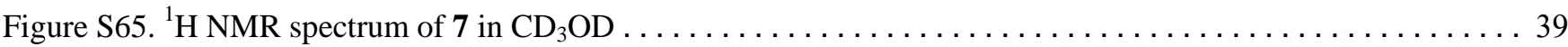

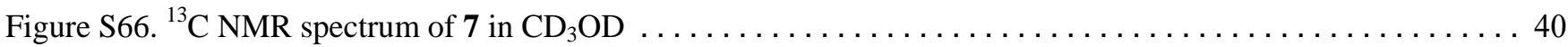

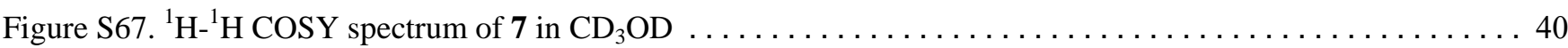

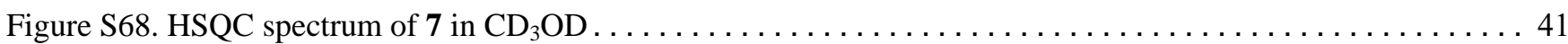

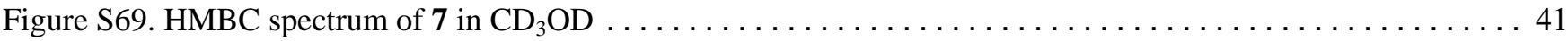

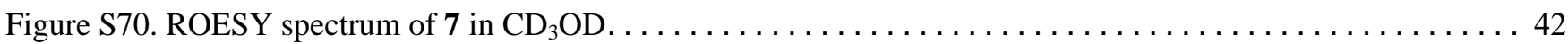

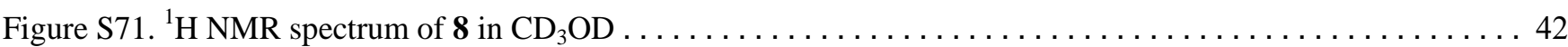

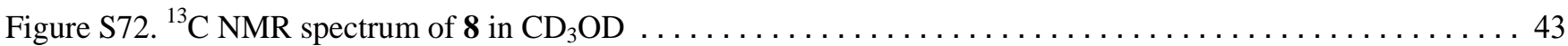

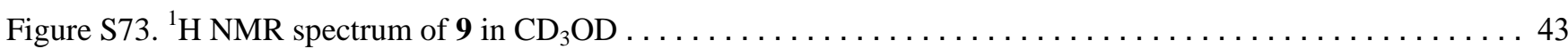

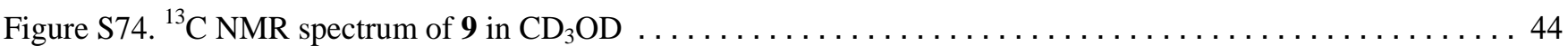

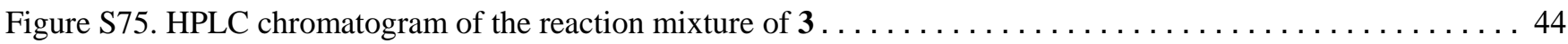

Figure S76. HPLC chromatogram of the reaction mixture of $4 \ldots \ldots \ldots \ldots \ldots \ldots \ldots \ldots \ldots \ldots \ldots \ldots \ldots$ 


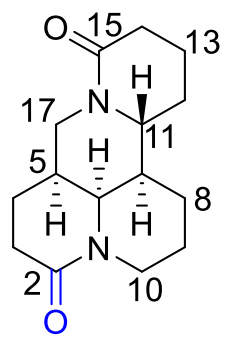

Figure S1. Chemical structure of compound 7

Table S2. Selective Index of Compounds against HBV in HepG2.2.15 Cells (Mean \pm SD, $n=3$ )

\begin{tabular}{ccccc}
\hline Compounds & $\mathrm{IC}_{50}(\mu \mathrm{M})^{\mathrm{a}}$ & $\mathrm{TC}_{50}(\mu \mathrm{M})^{\mathrm{b}}$ & $\mathrm{CC}_{50}(\mu \mathrm{M})^{\mathrm{c}}$ & $\mathrm{SI}^{\mathrm{d}}$ \\
\hline 1 & $44.85 \pm 7.30$ & $>500$ & $>500$ & $>11.15$ \\
3 & $86.60 \pm 4.30$ & $>500$ & $>500$ & $>5.77$ \\
4 & $32.11 \pm 2.83$ & $>500$ & $>500$ & $>15.57$ \\
5 & $74.28 \pm 0.31$, & $>500$ & $>500$ & $>6.73$ \\
6 & $70.62 \pm 0.93$ & $>500$ & $>500$ & $>7.08$ \\
7 & $17.16 \pm 0.38$ & $>500$ & $>500$ & $>33.56$ \\
8 & $14.90 \pm 0.53$ & $>500$ & $>500$ & $>67.84$ \\
9 & $7.37 \pm 0.17$ & $>500$ & $>500$ & $>31.87$ \\
PFA & $105.53 \pm 8.57$ & $>500$ & $>500$ & $>4.74$ \\
\hline
\end{tabular}

${ }^{\mathrm{a}} \mathrm{IC}_{50}$ : defined as the concentration that inhibited 50\% cellular HBV DNA in comparison to untreated controls in HepG2.2.15 cells. ${ }^{\mathrm{b}} \mathrm{TC}_{50}$ : defined as the concentration killing 50\% cells in comparison to untreated controls in HepG2.2.15 cells. ${ }^{\mathrm{c}} \mathrm{CC}_{50}$ : defined as the concentration for killing 50\% cells with no HBV infection as compared to that of untreated cells. ${ }^{\mathrm{d}}$ $\mathrm{SI}=\mathrm{TC}_{50} / \mathrm{IC}_{50}$. 


\section{MTT Assay.}

The assay of HepG2 cells uninfected with HBV was performed by MTT assay with the positive control cisplatin. Cells were cultured in RPMI-1640 medium (Gibco, USA) supplemented with 10\% FBS (Gibco, USA) and $1 \%$ penicillin/streptomycin at $37{ }^{\circ} \mathrm{C}$ with $5 \% \mathrm{CO}_{2}$. Cells at the logarithmic phase were seeded in 96-well plates at $5 \times 10^{3}$ cells per well. After preincubation overnight, cells were treated with various concentrations of compounds and cultured for $48 \mathrm{~h}$. Then, $40 \mu \mathrm{L}$ of $5 \mathrm{mg} / \mathrm{mL}$ MTT solutions was added to each well and incubated for $4 \mathrm{~h}$. After complete removal of the medium, $100 \mu \mathrm{L}$ of DMSO was added to each well to dissolve the formazan crystals. And the optical density (OD) was recorded at $570 \mathrm{~nm}$. The concentration for killing $50 \%$ cells $\left(\mathrm{CC}_{50}\right)$ was calculated by the Bliss method: inhibitory rate $=(1-$ the average OD value of the treatment group/the average OD value of the control group). 


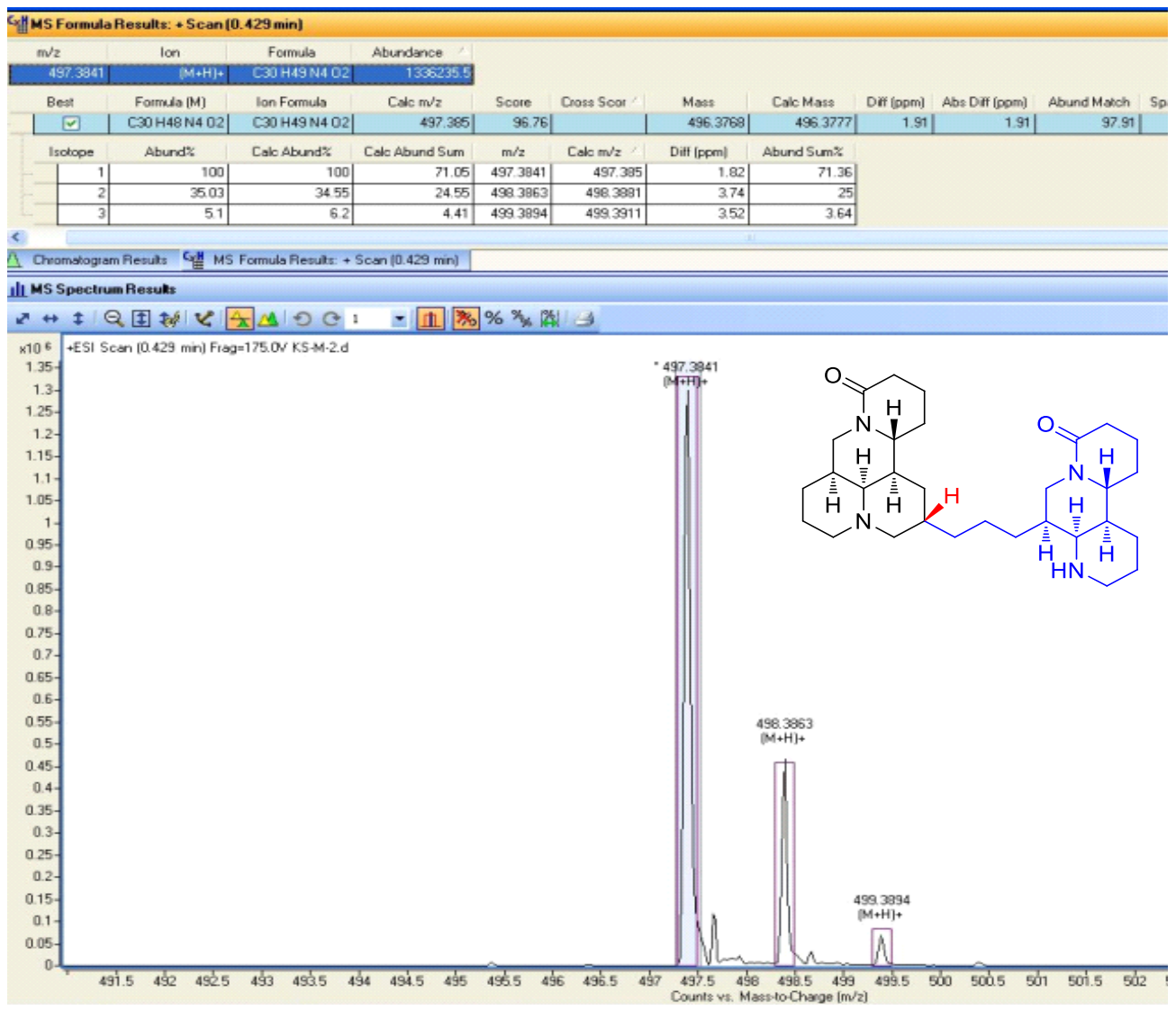

Figure S2. HR-ESI-MS spectrum of 1

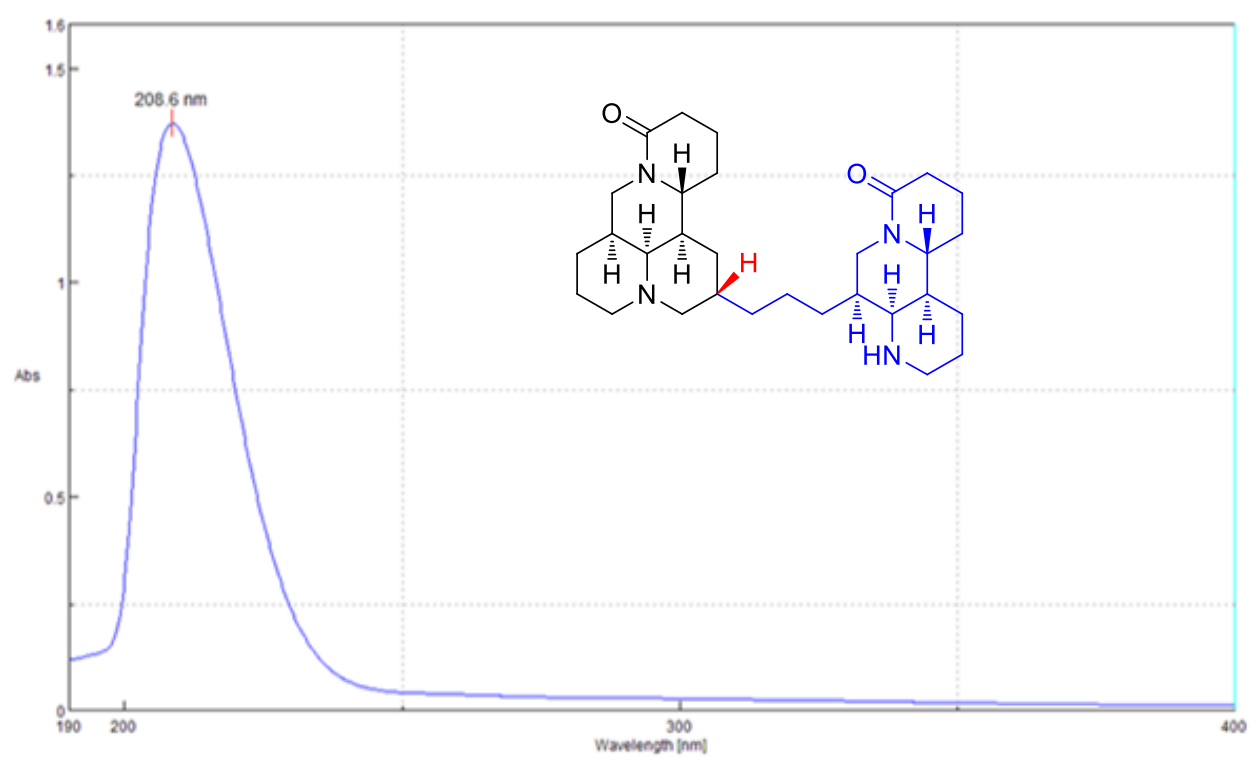

Figure S3. UV spectrum of $1\left(\mathrm{CH}_{3} \mathrm{OH}\right)$ 


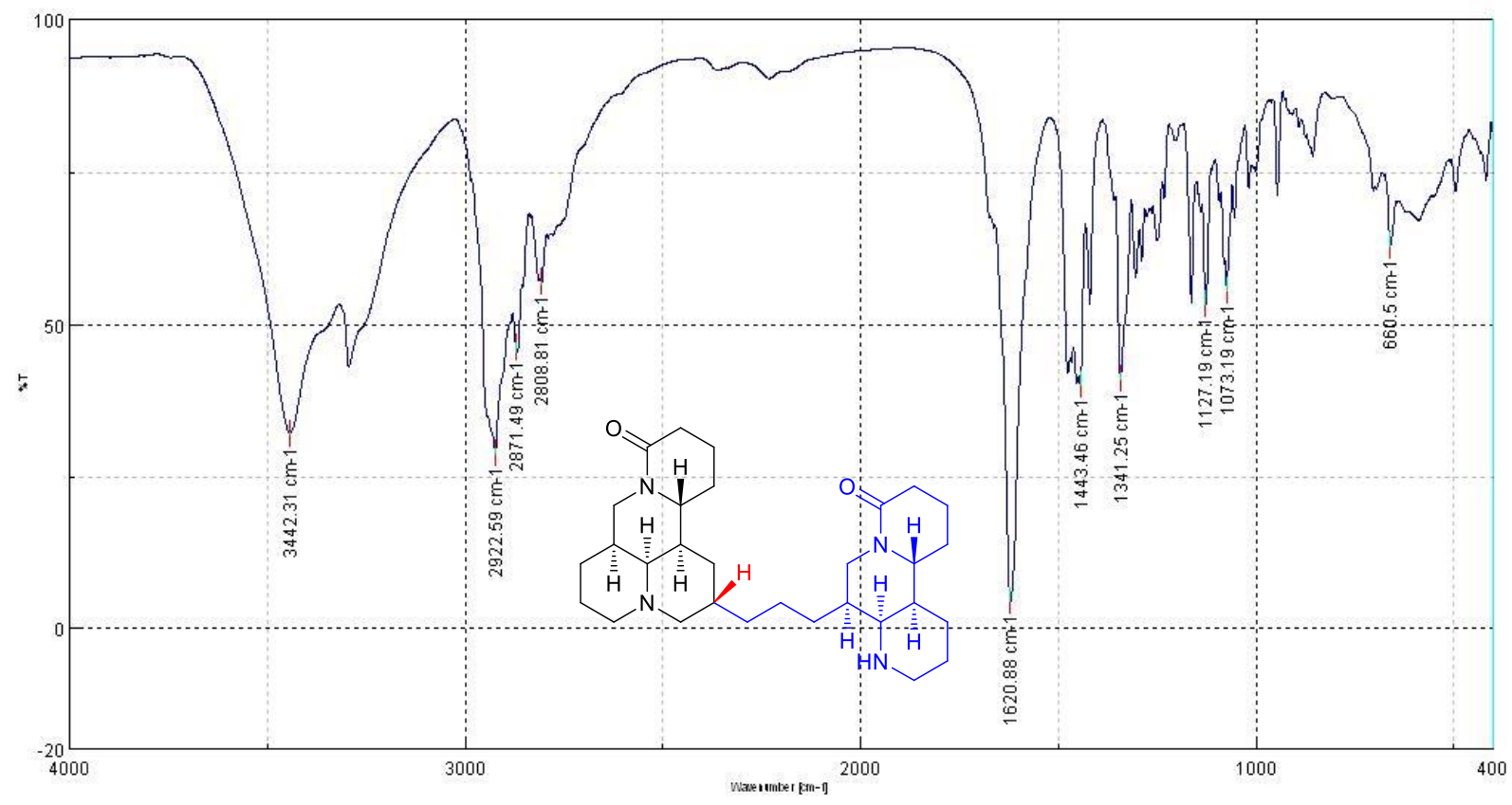

Figure S4. IR spectrum of 1 (KBr disc)

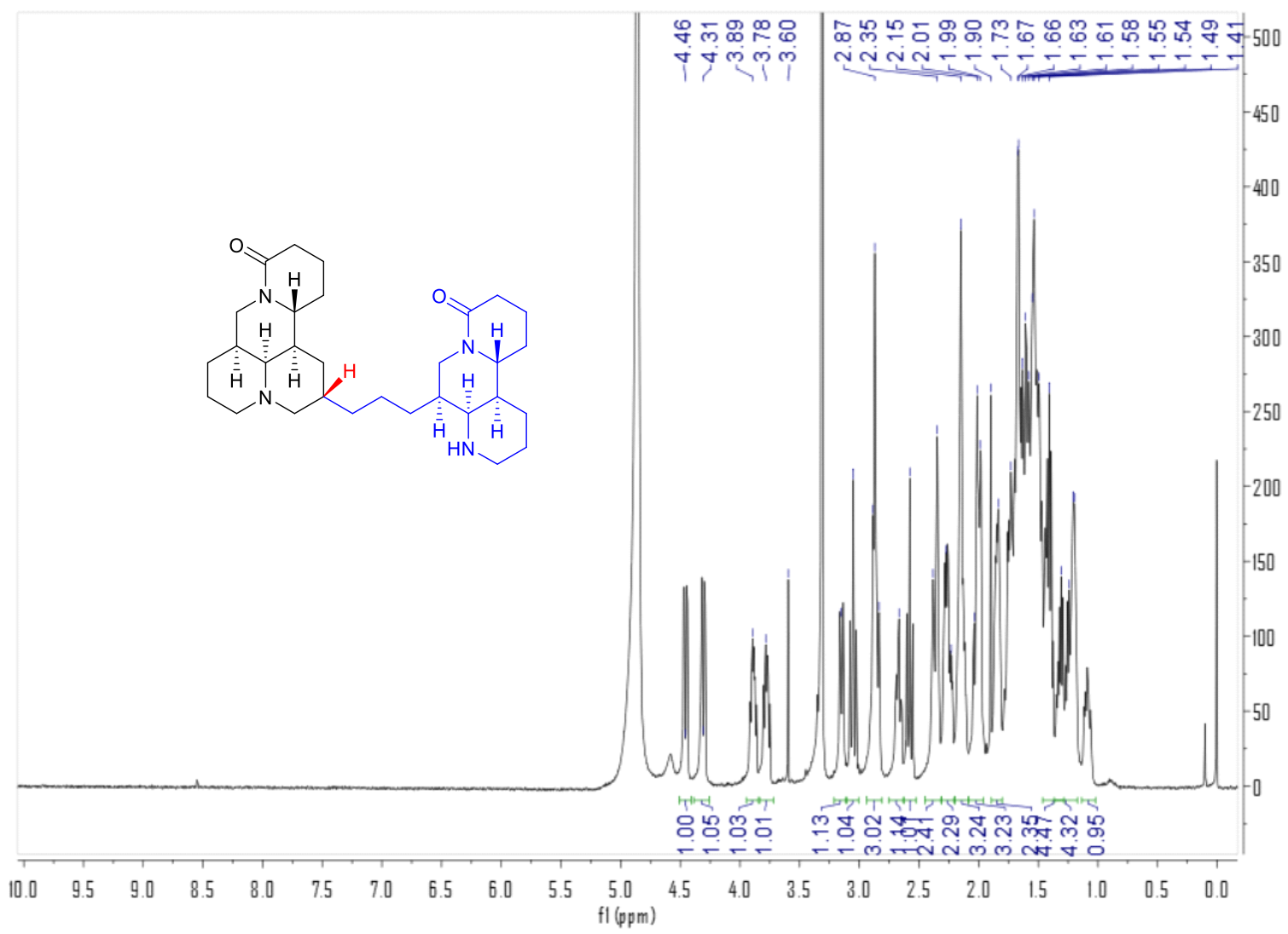

Figure S5. ${ }^{1} \mathrm{H}$ NMR spectrum of 1 in $\mathrm{CD}_{3} \mathrm{OD}$ 


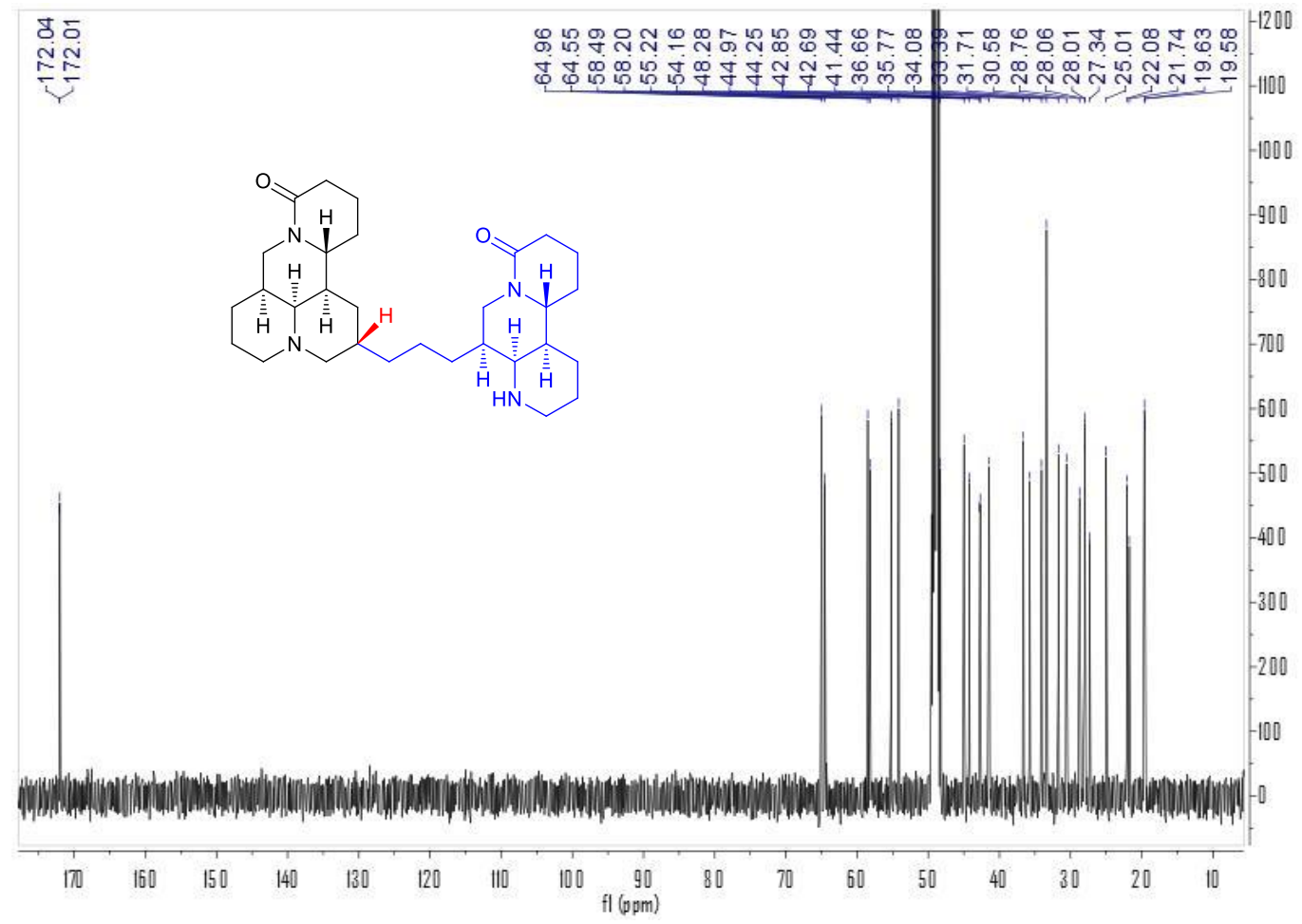

Figure S6. ${ }^{13} \mathrm{C}$ NMR spectrum of 1 in $\mathrm{CD}_{3} \mathrm{OD}$

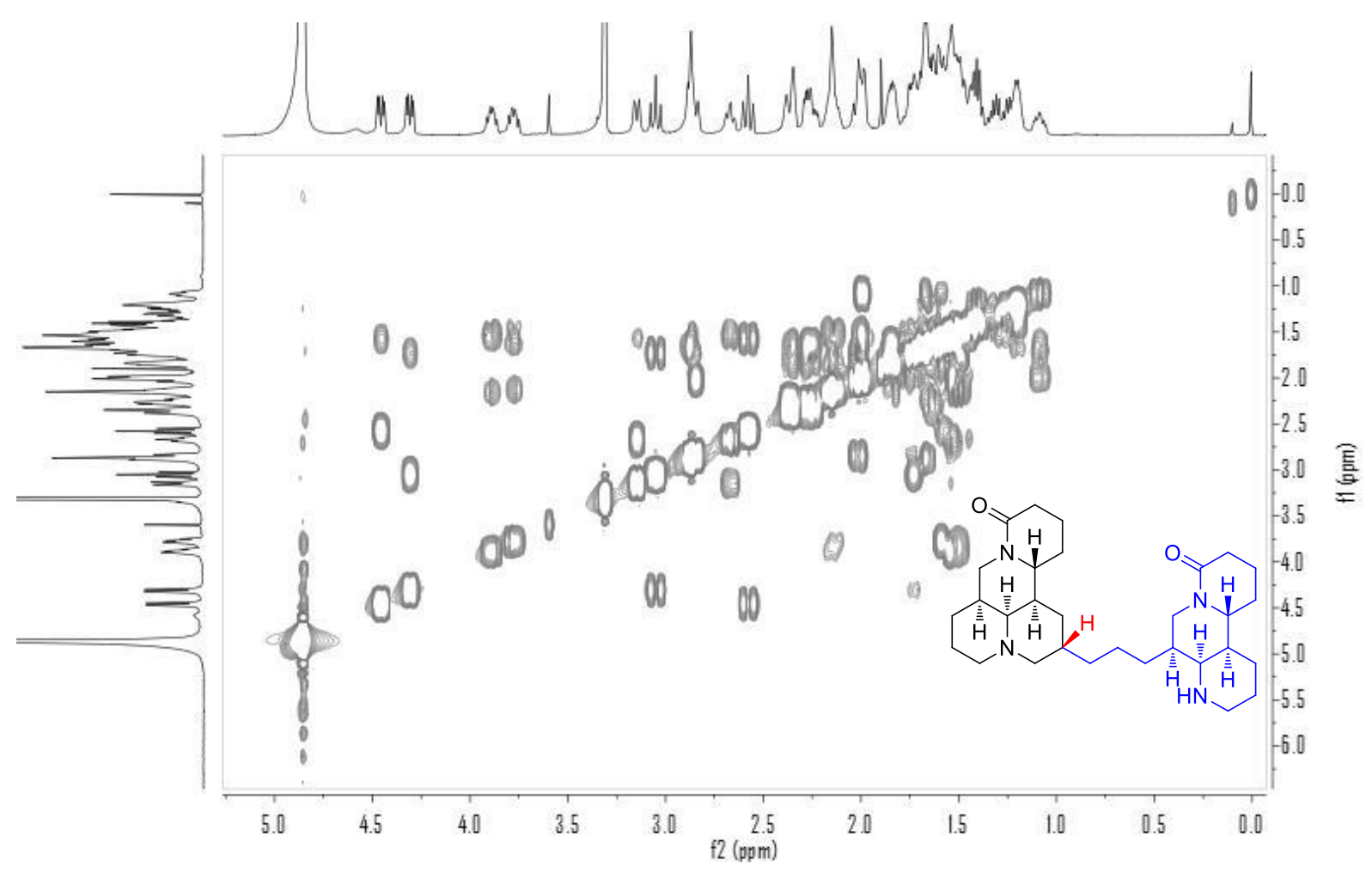

Figure $\mathrm{S} 7{ }^{1} \mathrm{H}-{ }^{1} \mathrm{H}$ COSY spectrum of 1 in $\mathrm{CD}_{3} \mathrm{OD}$ 


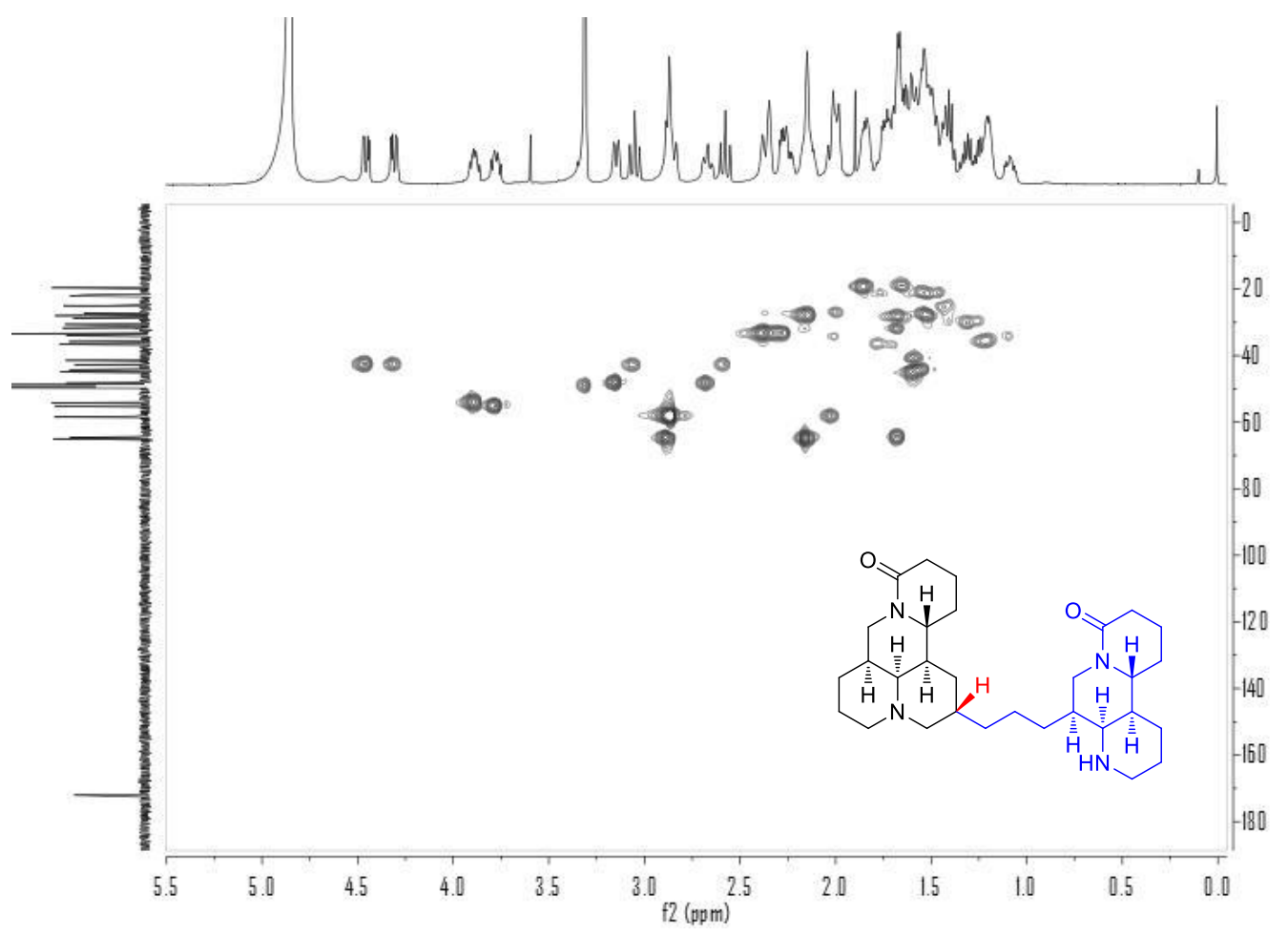

Figure S8. HSQC spectrum of 1 in $\mathrm{CD}_{3} \mathrm{OD}$

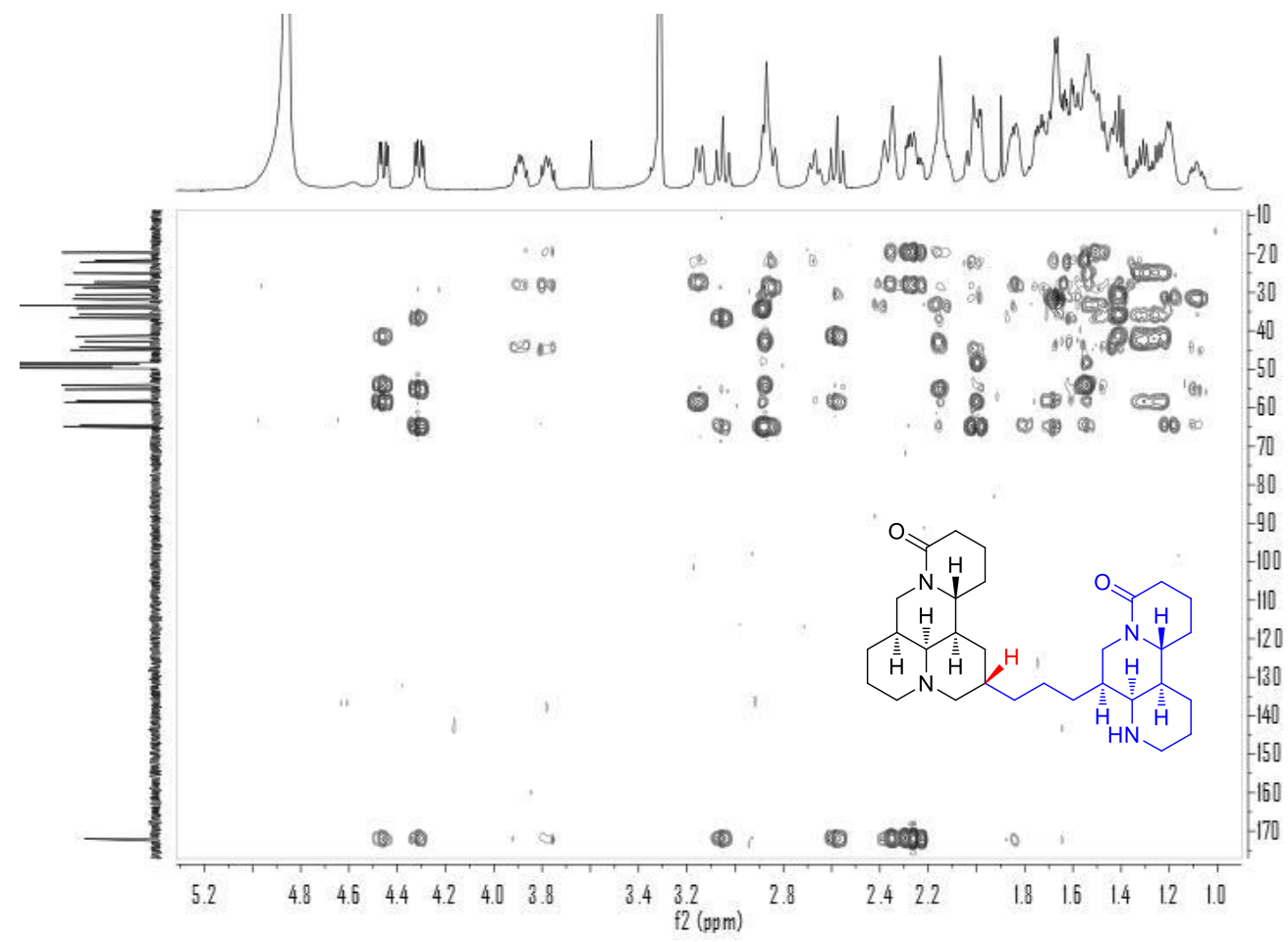

Figure S9. HMBC spectrum of 1 in $\mathrm{CD}_{3} \mathrm{OD}$ 


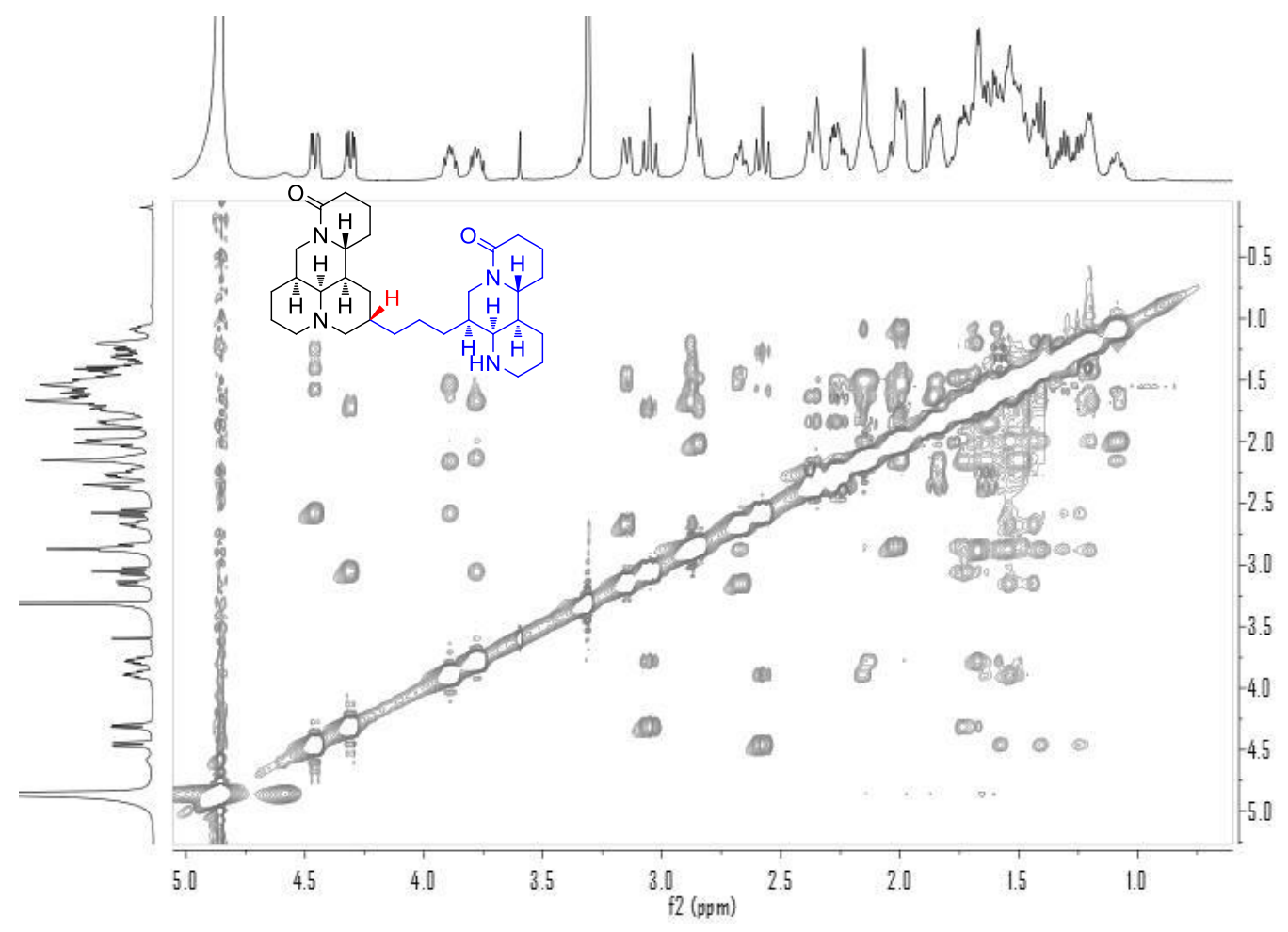

Figure S10. ROESY spectrum of 1 in $\mathrm{CD}_{3} \mathrm{OD}$

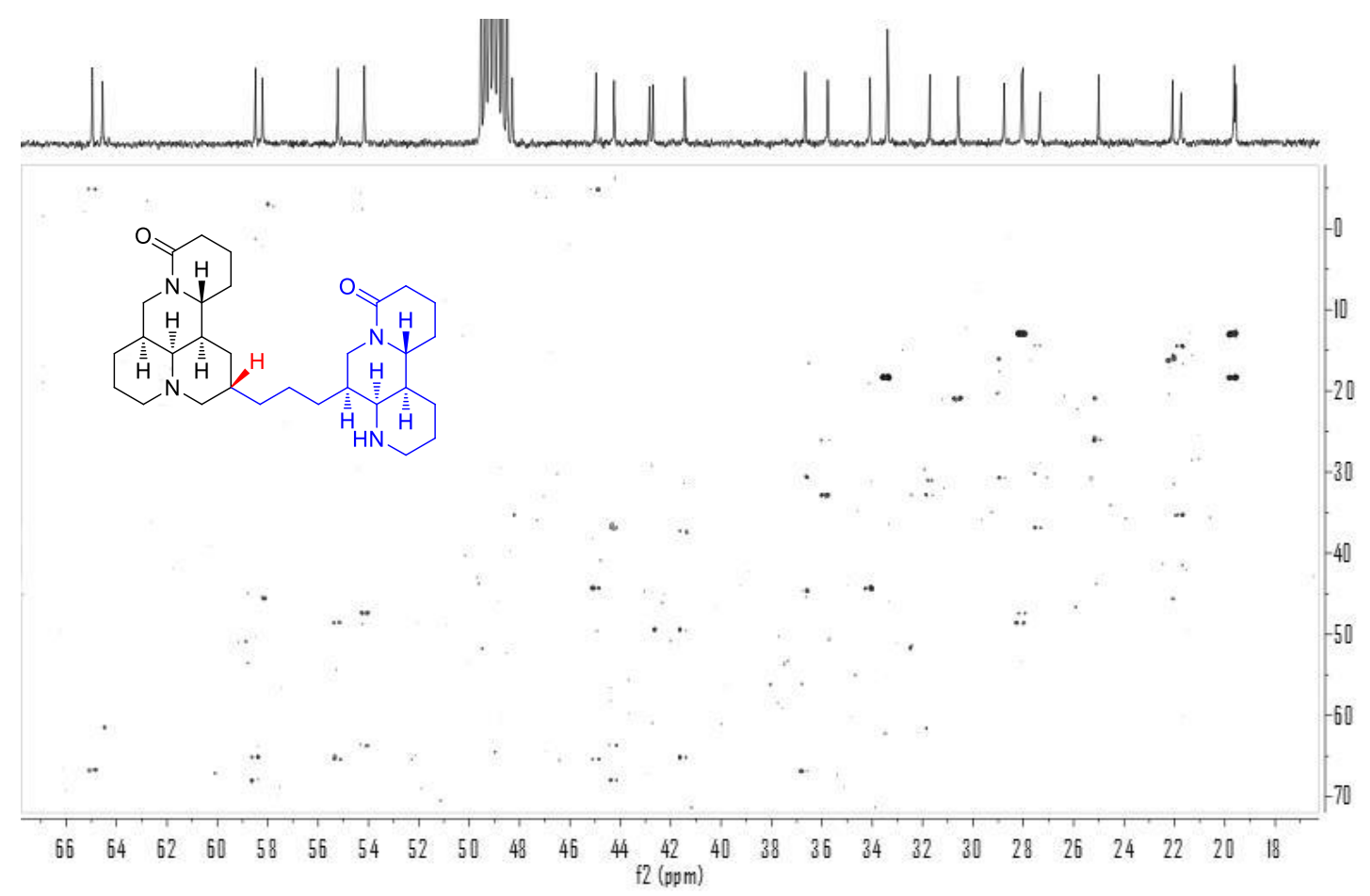

Figure S11. 2D INADEQUATE spectrum of 1 in $\mathrm{CD}_{3} \mathrm{OD}$ 


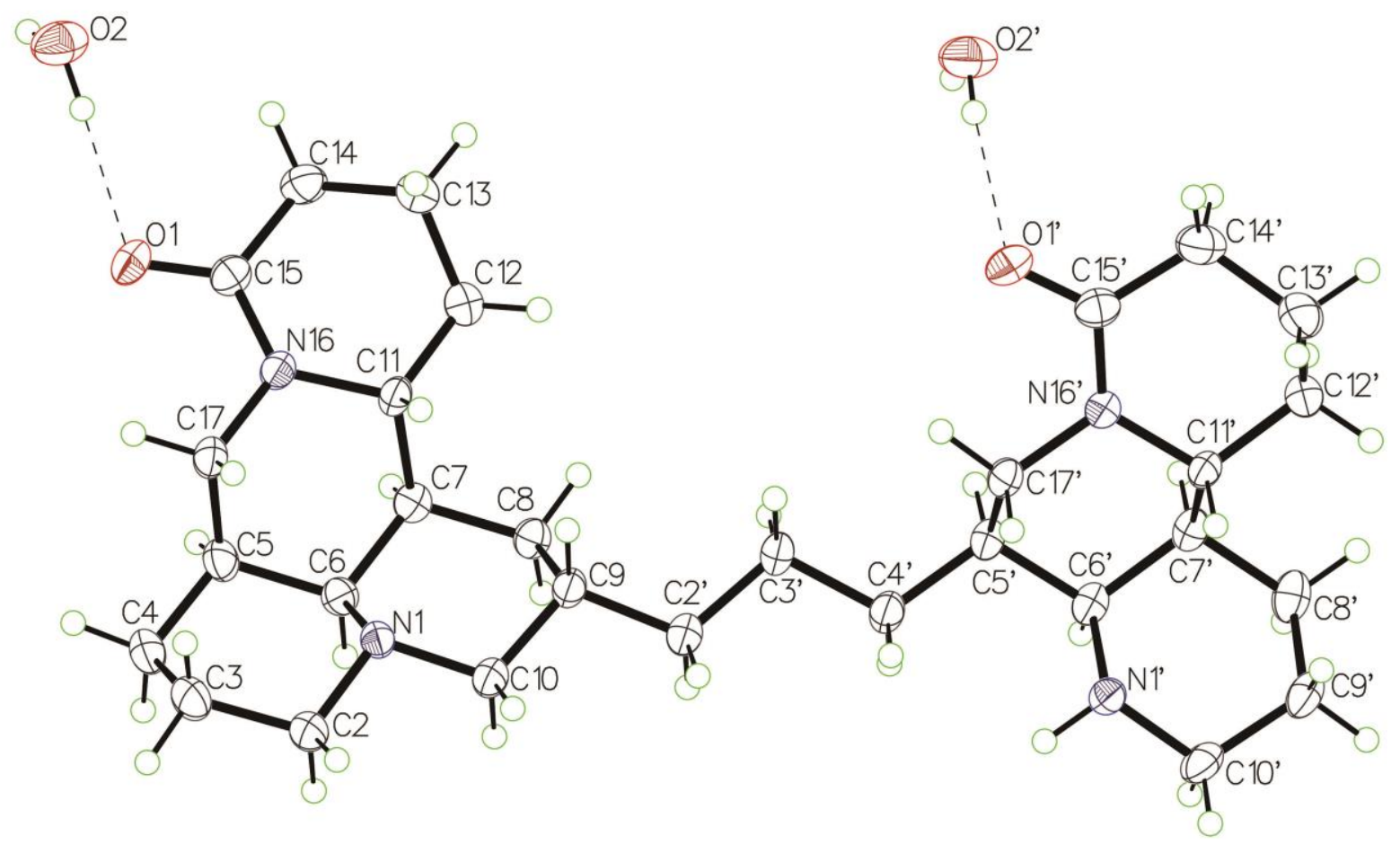

Figure S12. X-ray ORTEP drawings of 1. The thermal ellipsoids are scaled to the $50 \%$ probability level 


\section{X-ray crystallographic data of 1}

Empirical formula

Formula weight

Temperature/K

Crystal system

Space group

$a / \AA$

$b / \AA$

$c / \AA$

$\alpha /^{\circ}$

$\beta /^{\circ}$

$\gamma /{ }^{\circ}$

Volume/ $\AA^{3}$

Z

$\rho_{\text {calc }} \mathrm{g} / \mathrm{cm}^{3}$

$\mu / \mathrm{mm}^{-1}$

$F(000)$

Crystal size $/ \mathrm{mm}^{3}$

Radiation

$2 \Theta$ range for data collection ${ }^{\circ}$

Index ranges

Reflections collected

Independent reflections

Data/restraints/parameters

Goodness-of-fit on $\mathrm{F}^{2}$

Final R indexes $[\mathrm{I}>=2 \sigma(\mathrm{I})]$

Final $\mathrm{R}$ indexes [all data]

Largest diff. peak/hole / e $\AA^{-3}$

Hooft parameter

Flack parameter
$\mathrm{C}_{30} \mathrm{H}_{52} \mathrm{~N}_{4} \mathrm{O}_{4}$

532.76

173

monoclinic

$P 2_{1}$

$8.6676(2)$

$19.3296(4)$

$9.4016(3)$

90.00

111.219(3)

90.00

1468.36(7)

2

1.205

0.632

584.0

$0.28 \times 0.25 \times 0.2$

$\mathrm{CuK} \alpha(\lambda=1.54184)$

9.16 to 125.42

$-9 \leq \mathrm{h} \leq 9,-22 \leq \mathrm{k} \leq 22,-10 \leq 1 \leq 10$

17235

$4683\left[\mathrm{R}_{\text {int }}=0.0521, \mathrm{R}_{\text {sigma }}=0.0378\right]$

$4683 / 1 / 352$

1.077

$\mathrm{R}_{1}=0.0327, \mathrm{wR}_{2}=0.0792$

$\mathrm{R}_{1}=0.0354, \mathrm{wR}_{2}=0.0824$

$0.21 /-0.15$

$0.03(11)$

$0.10(17)$ 


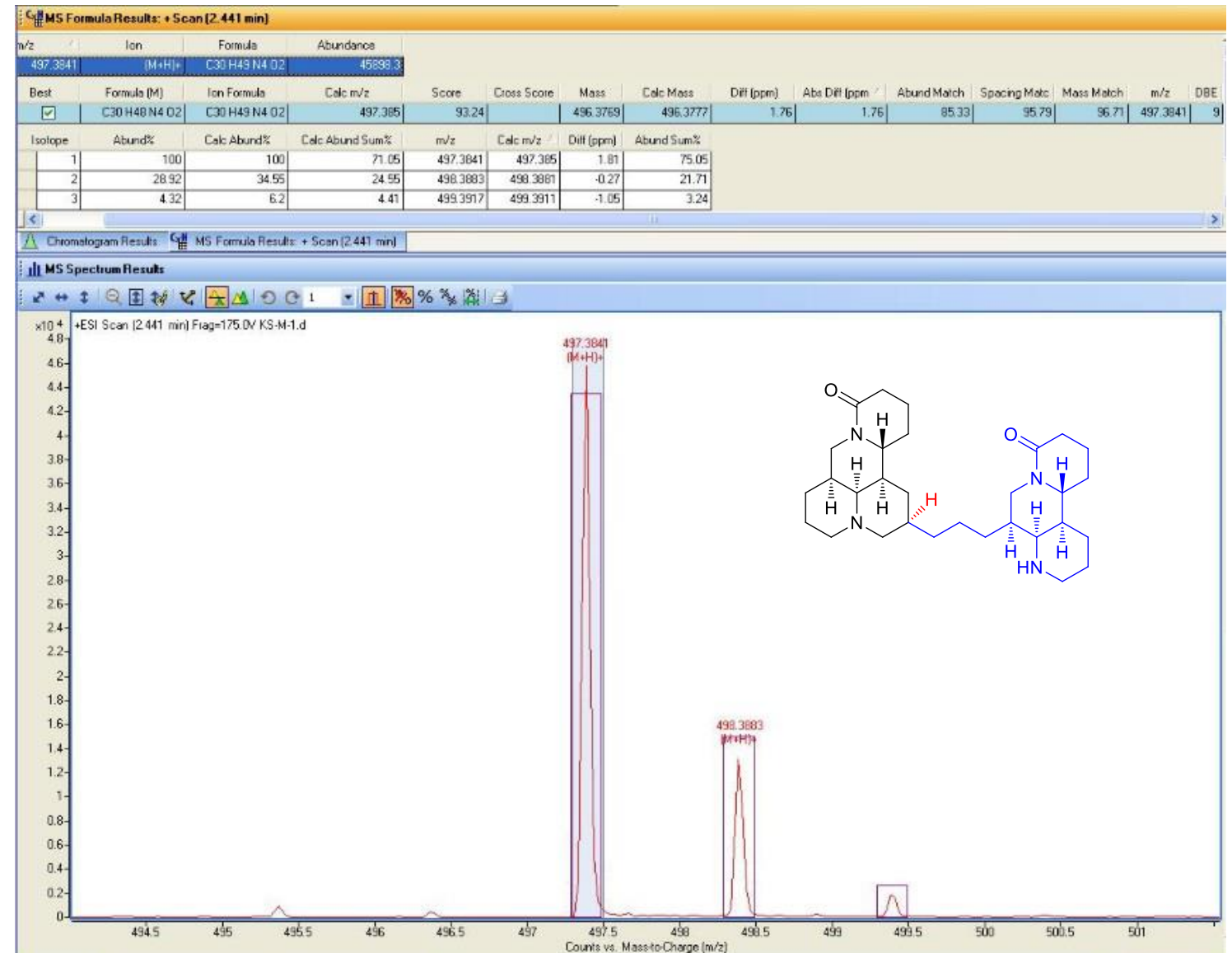

Figure S13. HR-ESI-MS spectrum of 2

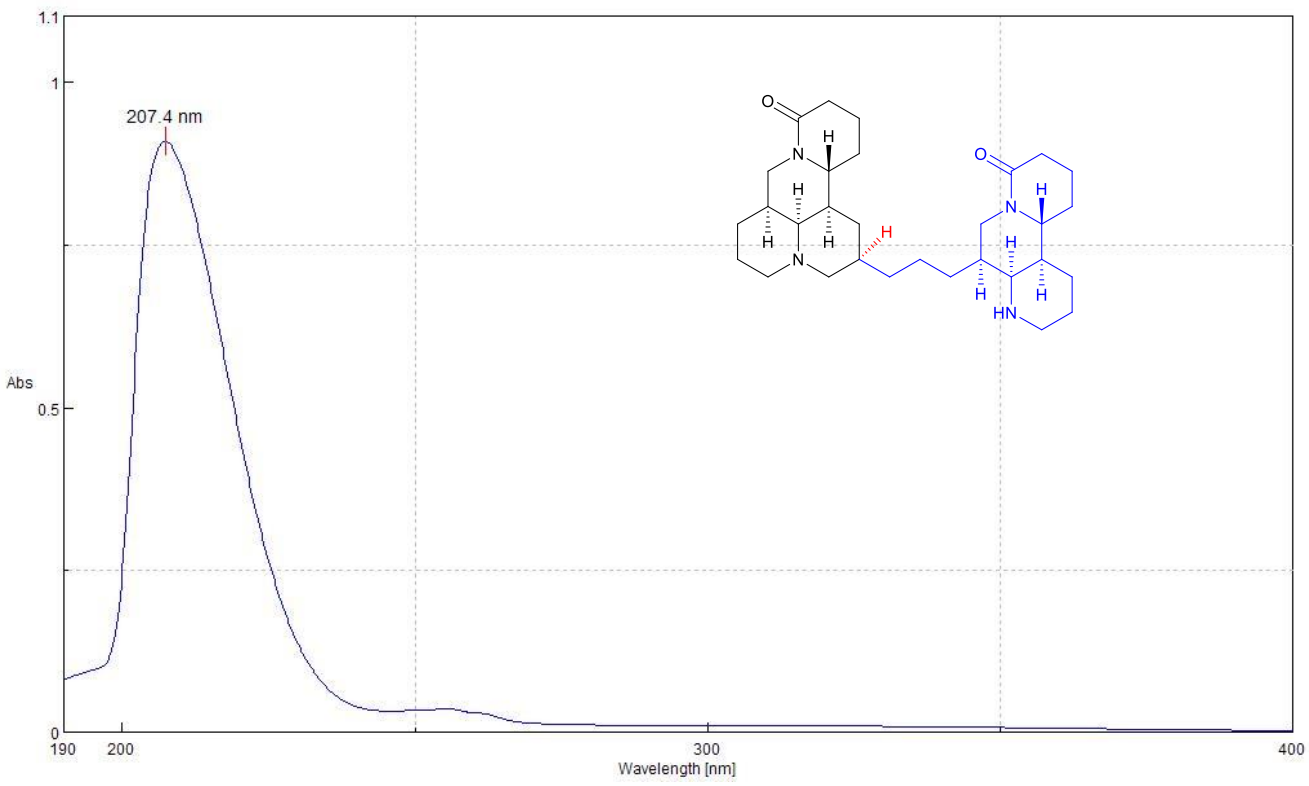

Figure S14. UV spectrum of $2\left(\mathrm{CH}_{3} \mathrm{OH}\right)$ 


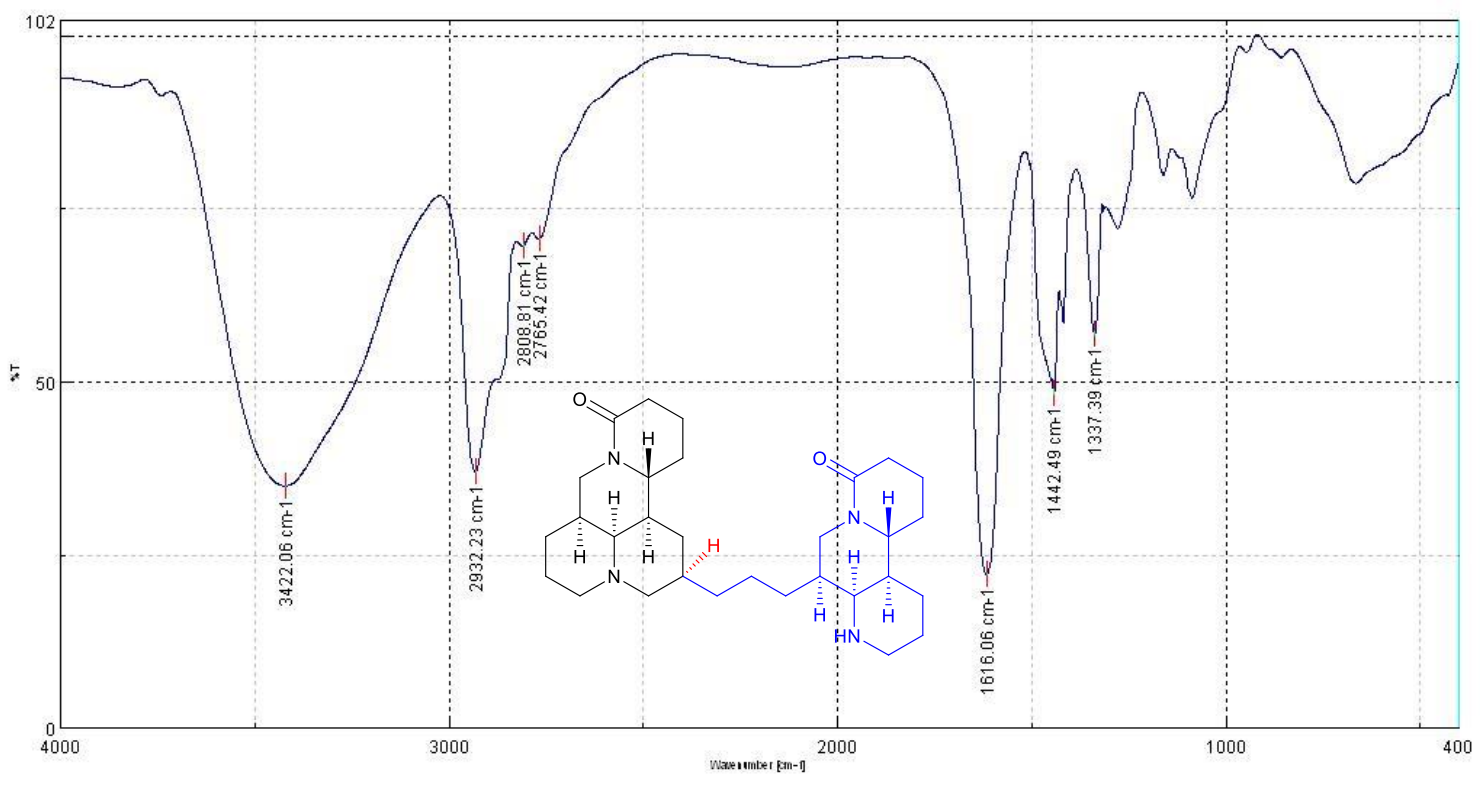

Figure S15. IR spectrum of 2 (KBr disc)

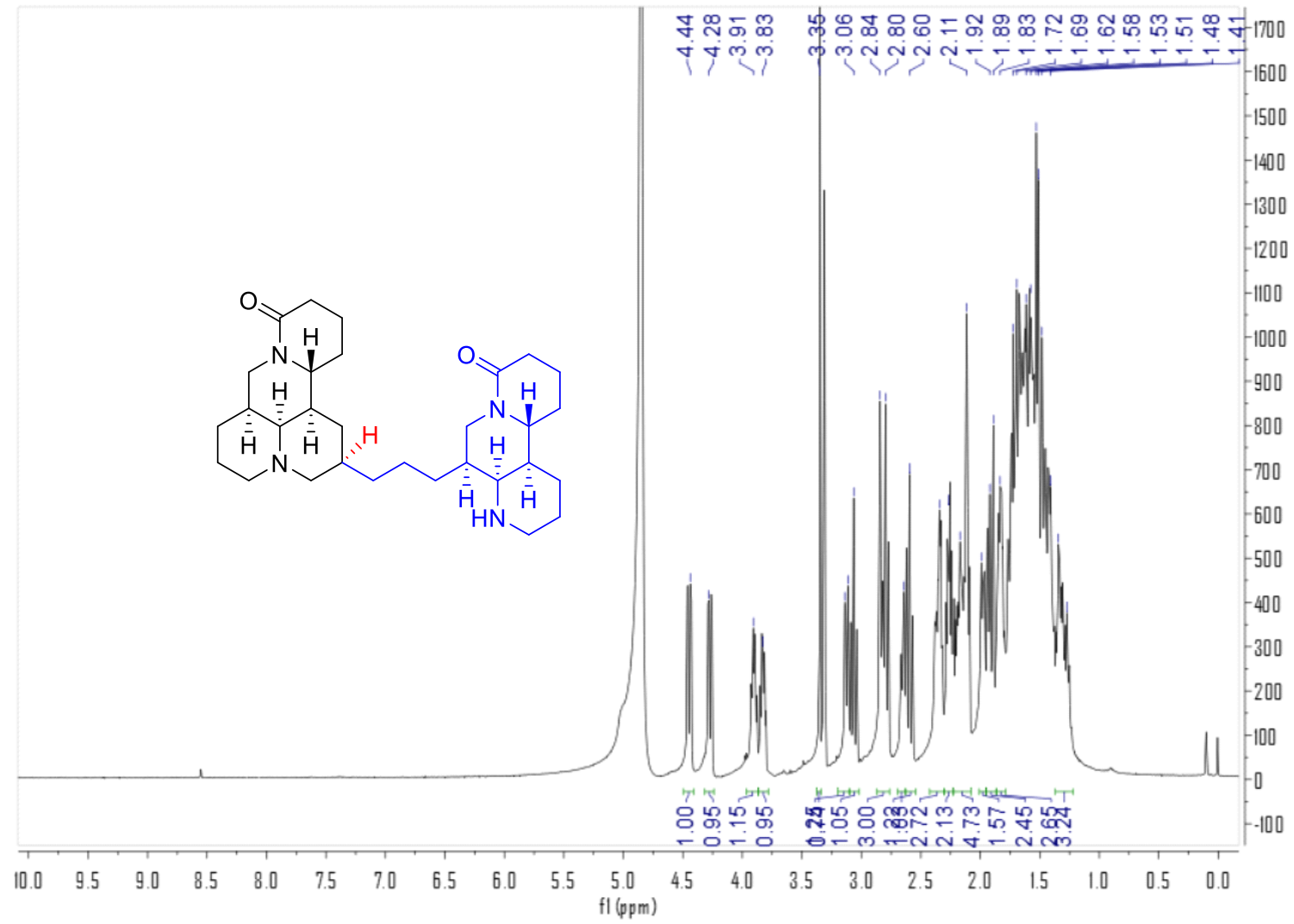

Figure S16. ${ }^{1} \mathrm{H}$ NMR spectrum of 2 in $\mathrm{CD}_{3} \mathrm{OD}$ 


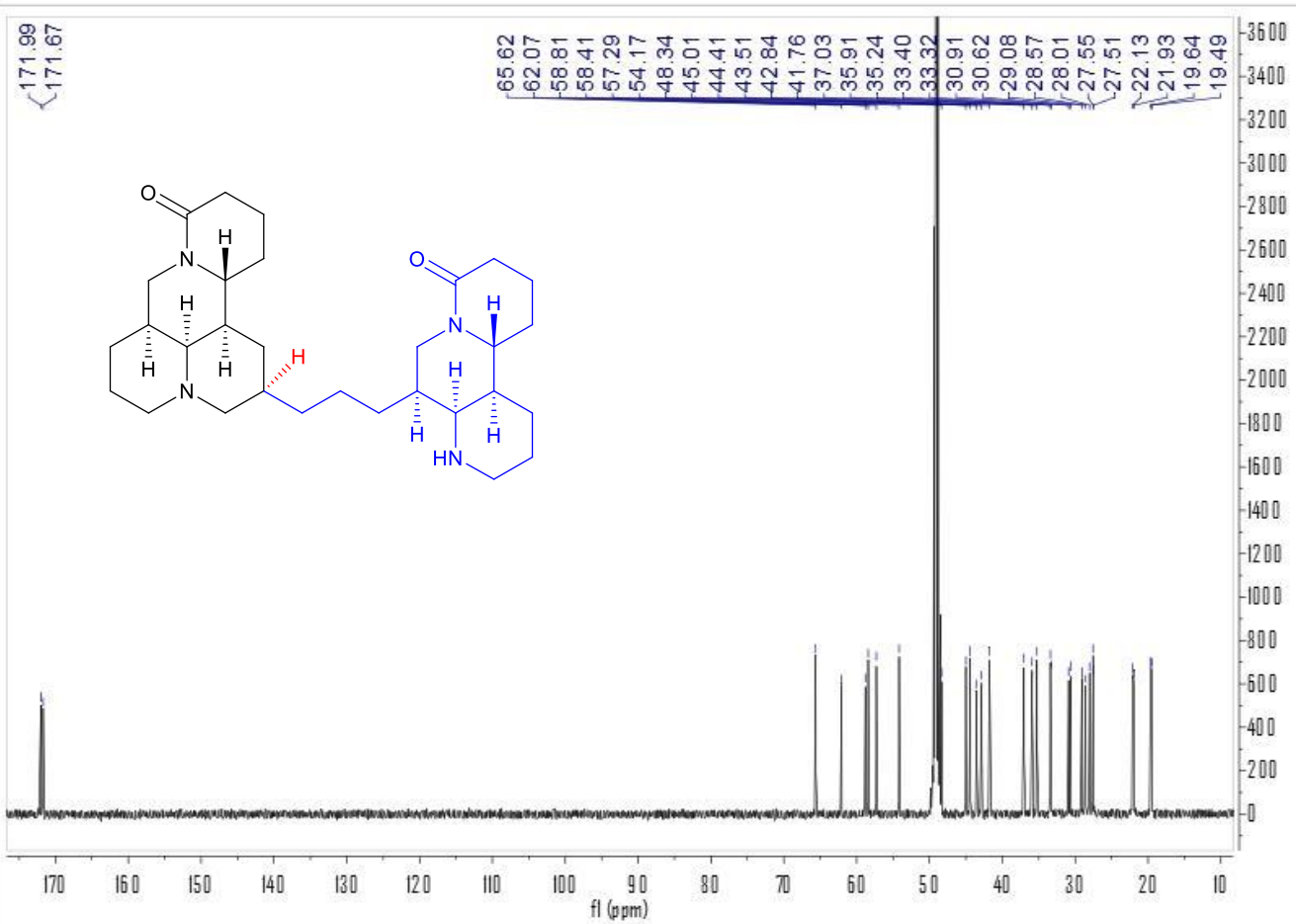

Figure S17. ${ }^{13} \mathrm{C}$ NMR spectrum of 2 in $\mathrm{CD}_{3} \mathrm{OD}$

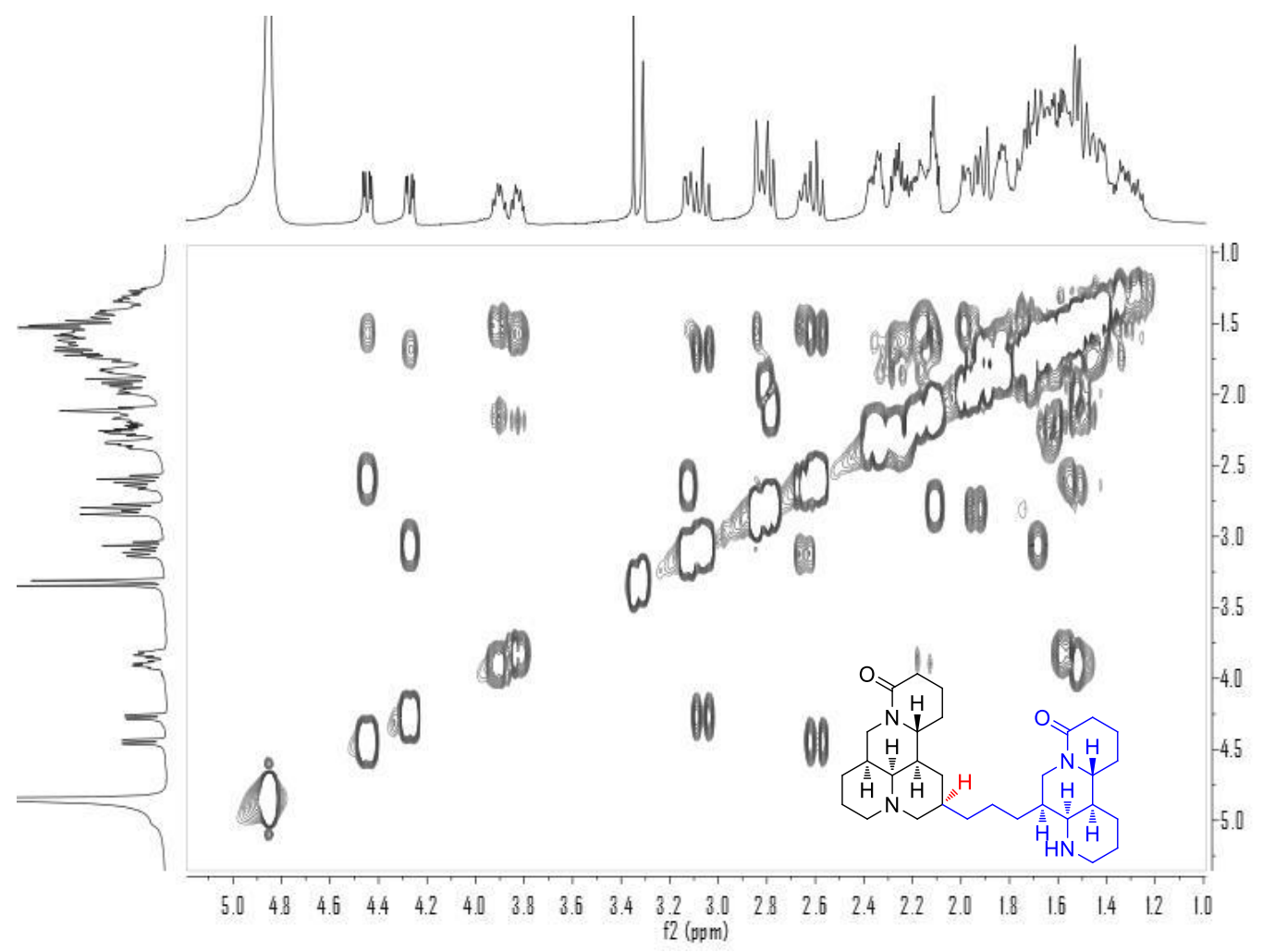

Figure S18. ${ }^{1} \mathrm{H}-{ }^{1} \mathrm{H}$ COSY spectrum of 2 in $\mathrm{CD}_{3} \mathrm{OD}$ 


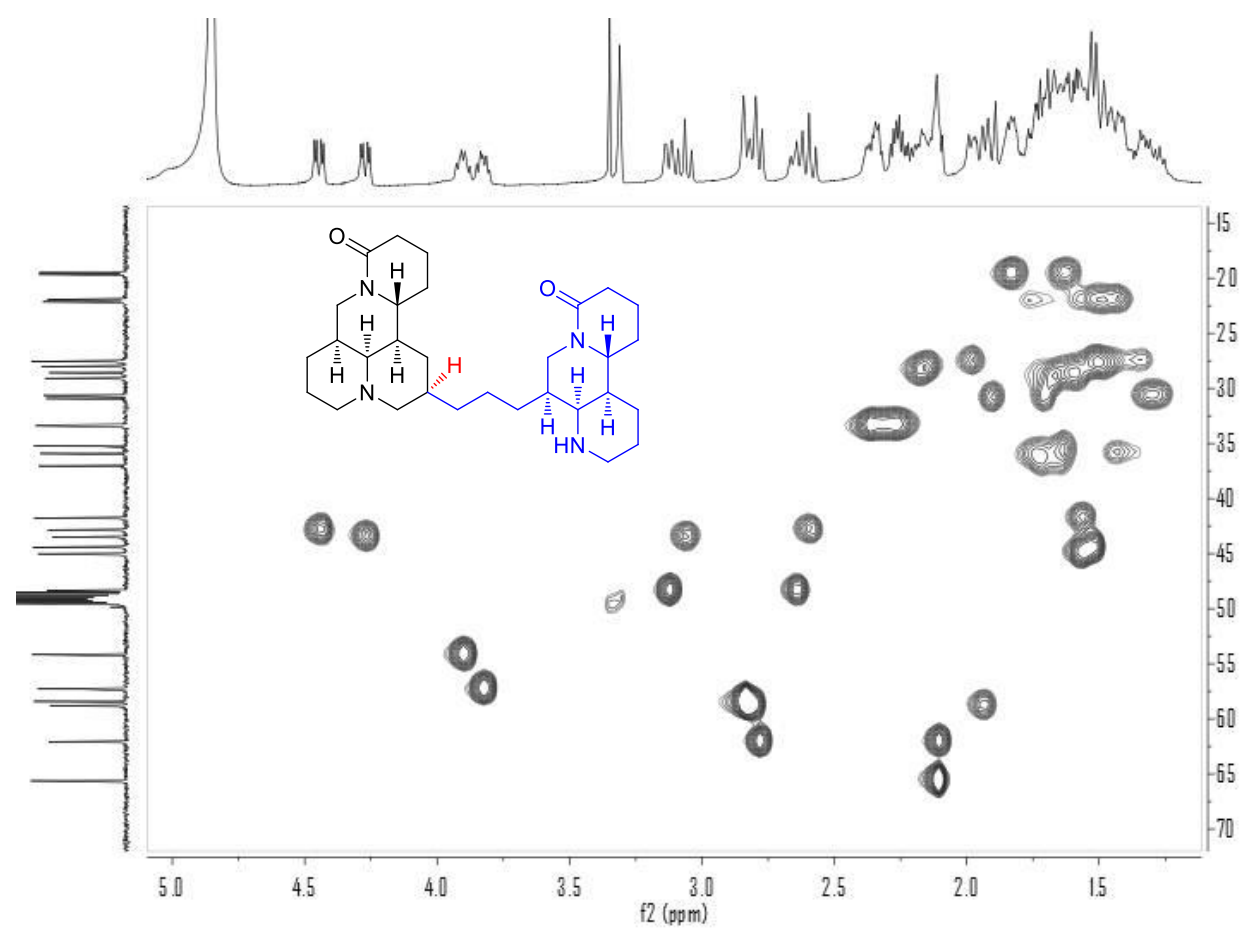

Figure S19. HSQC spectrum of 2 in $\mathrm{CD}_{3} \mathrm{OD}$

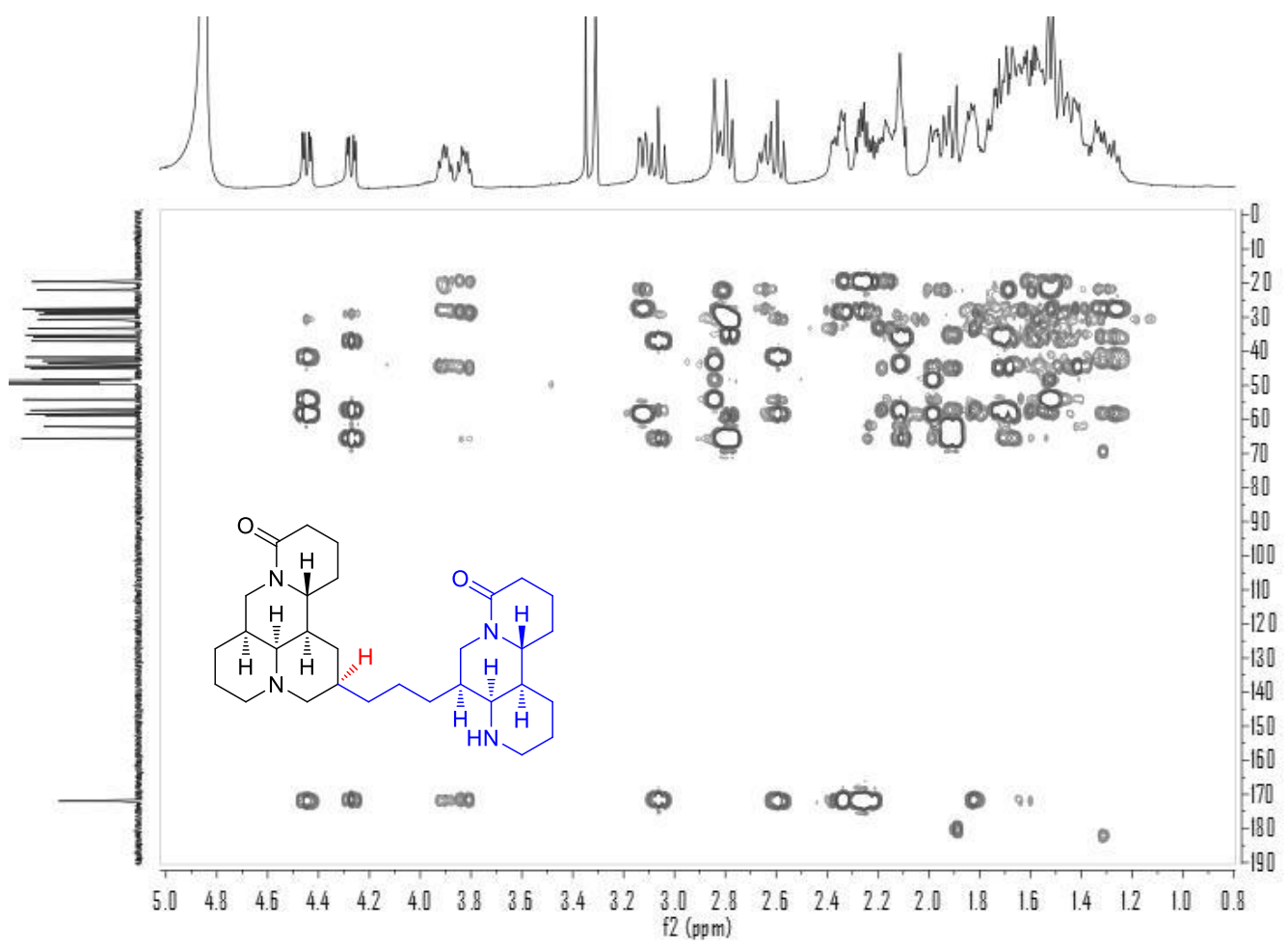

Figure S20. $\mathrm{HMBC}$ spectrum of 2 in $\mathrm{CD}_{3} \mathrm{OD}$ 


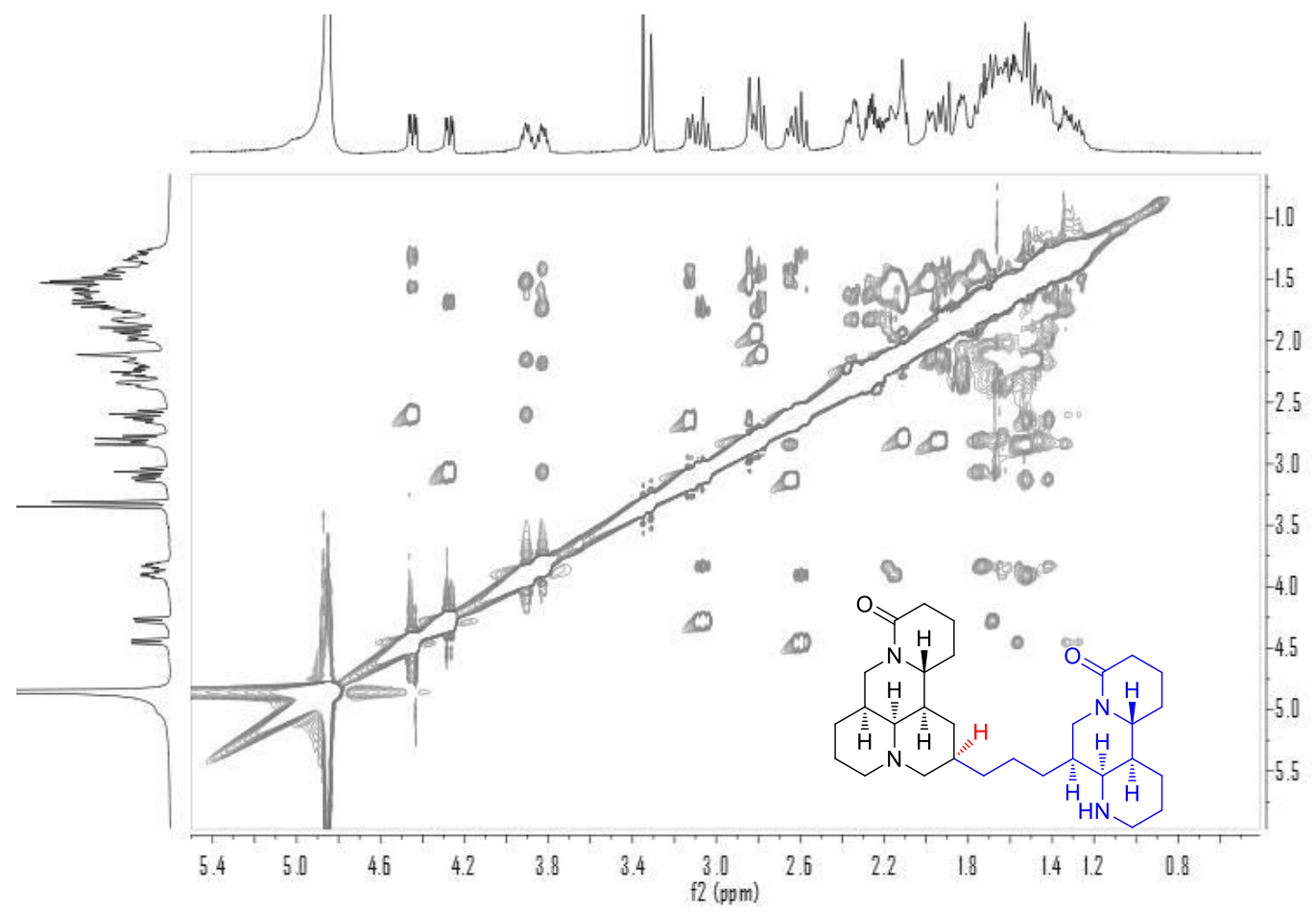

Figure S21. ROESY spectrum of 2 in $\mathrm{CD}_{3} \mathrm{OD}$

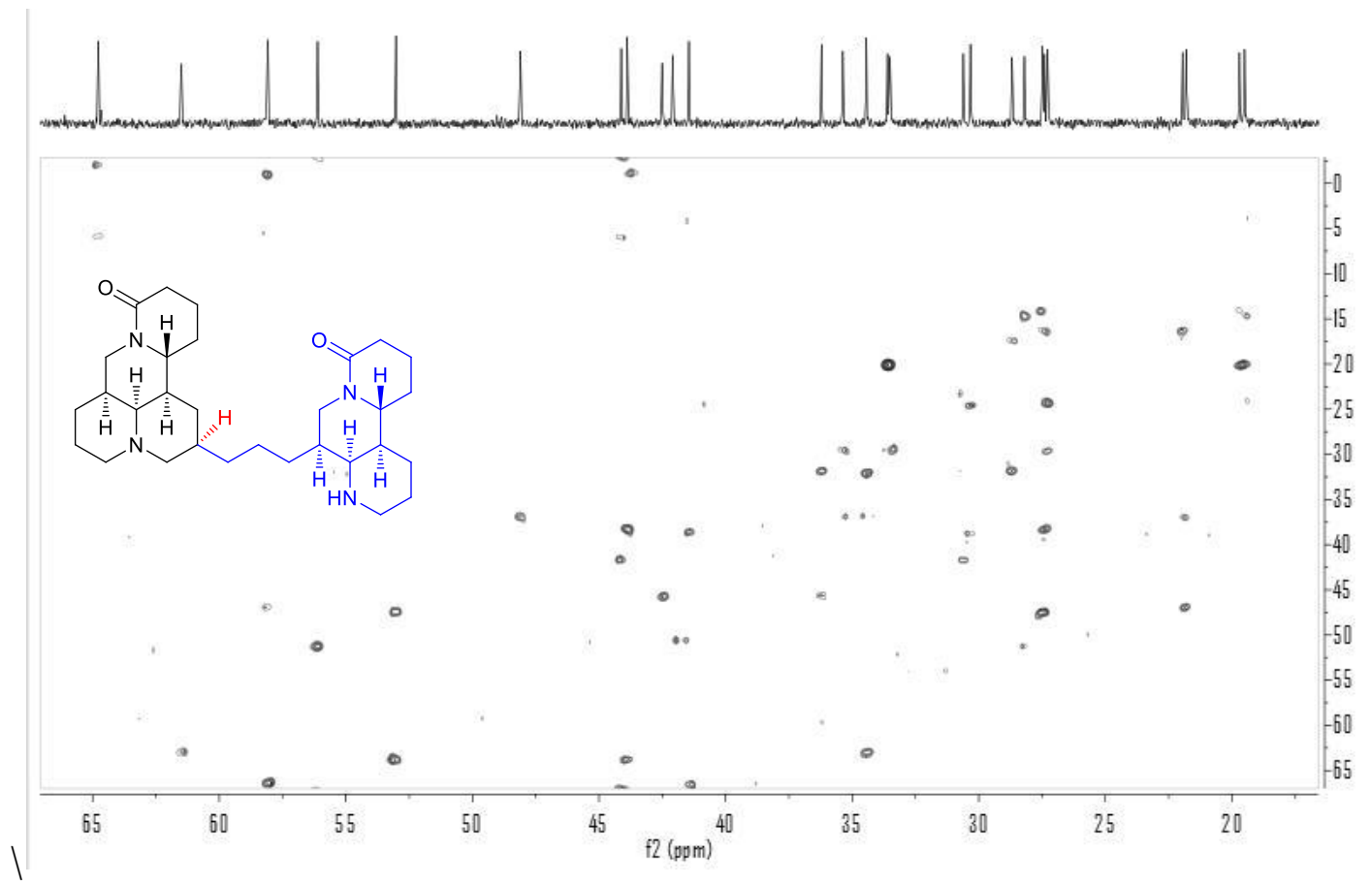

Figure S22. 2D INADEQUATE spectrum of 2 in $\mathrm{C}_{5} \mathrm{D}_{5} \mathrm{~N}$ 


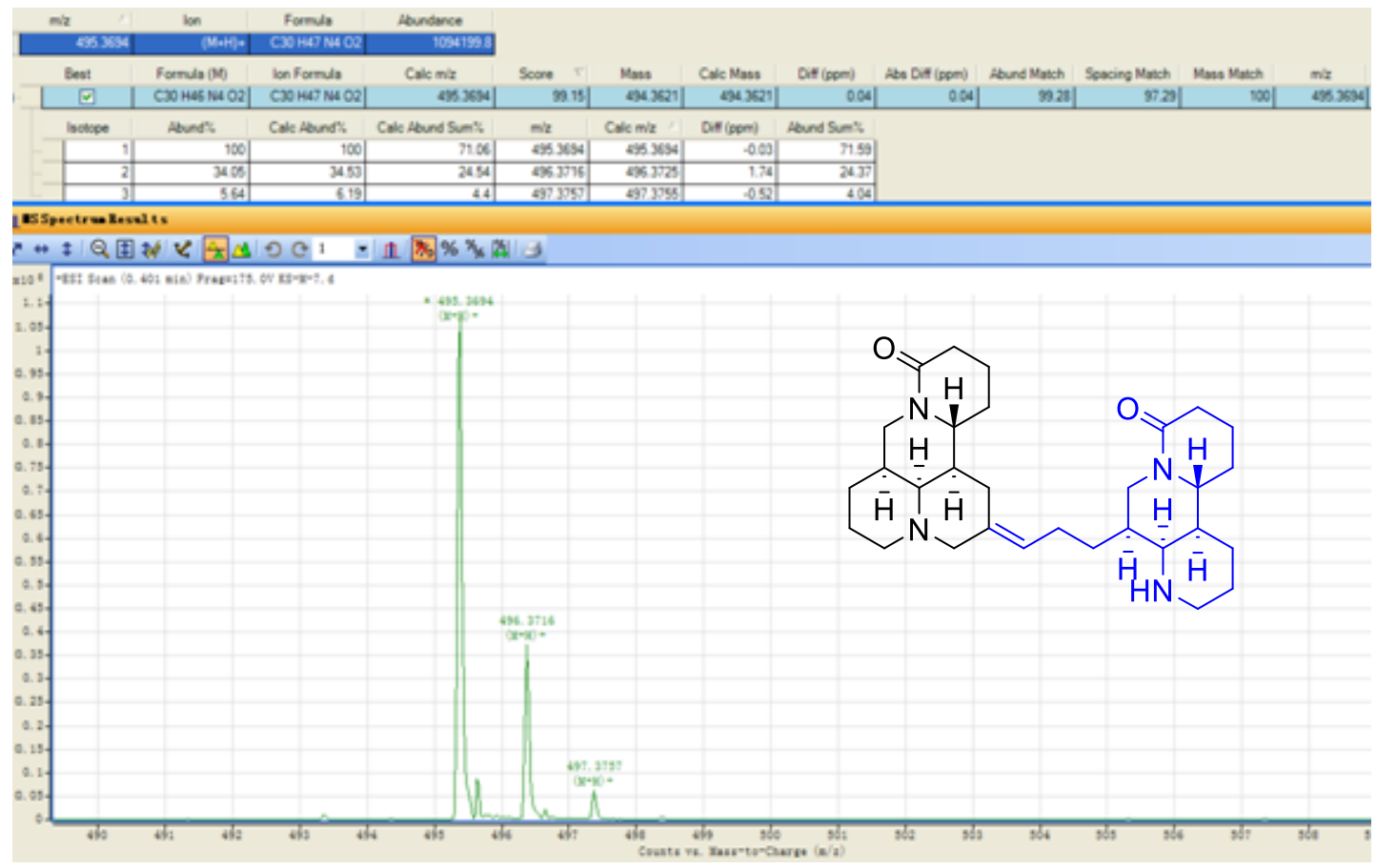

Figure S23. HR-ESI-MS spectrum of 3

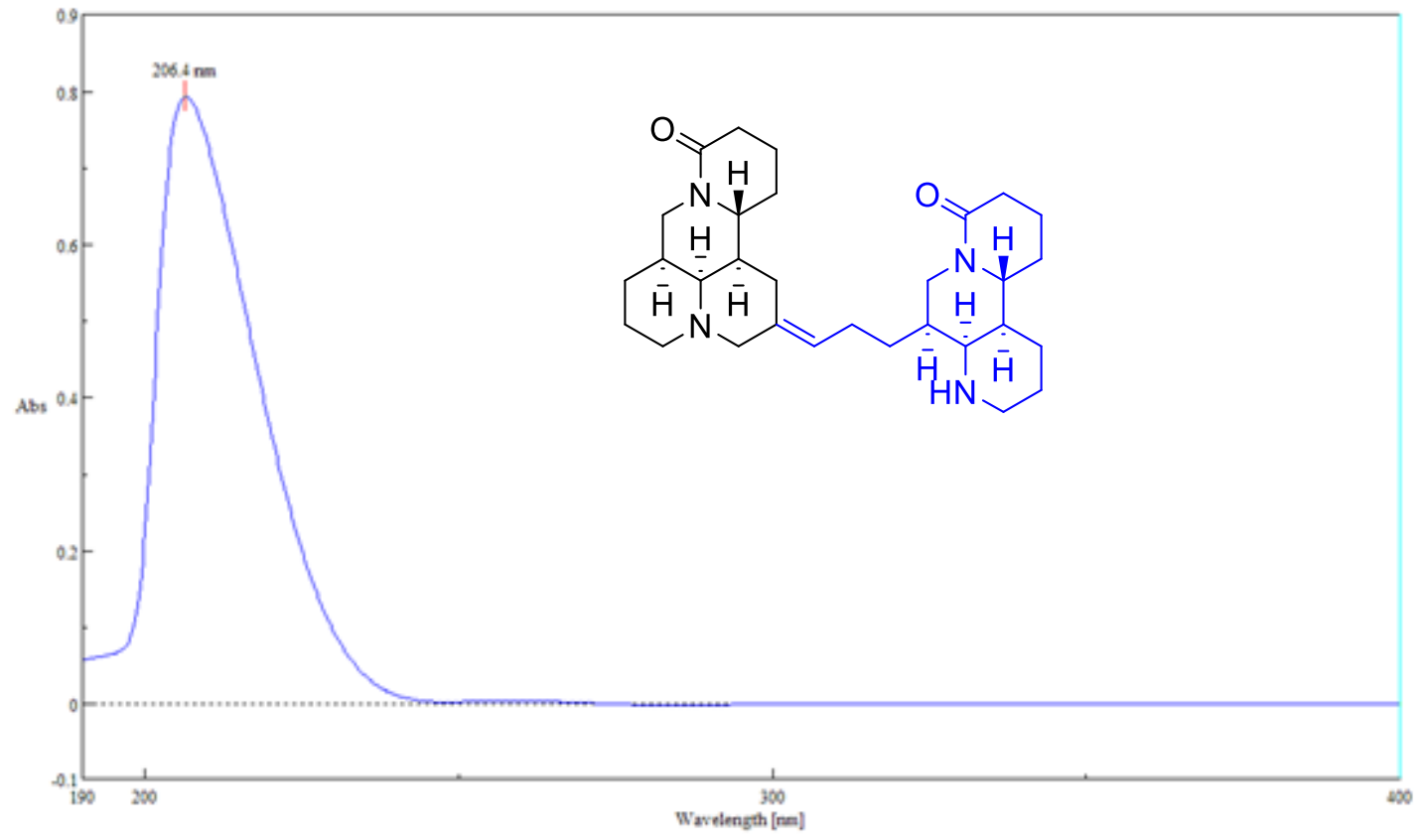

Figure S24. UV spectrum of $3\left(\mathrm{CH}_{3} \mathrm{OH}\right)$ 


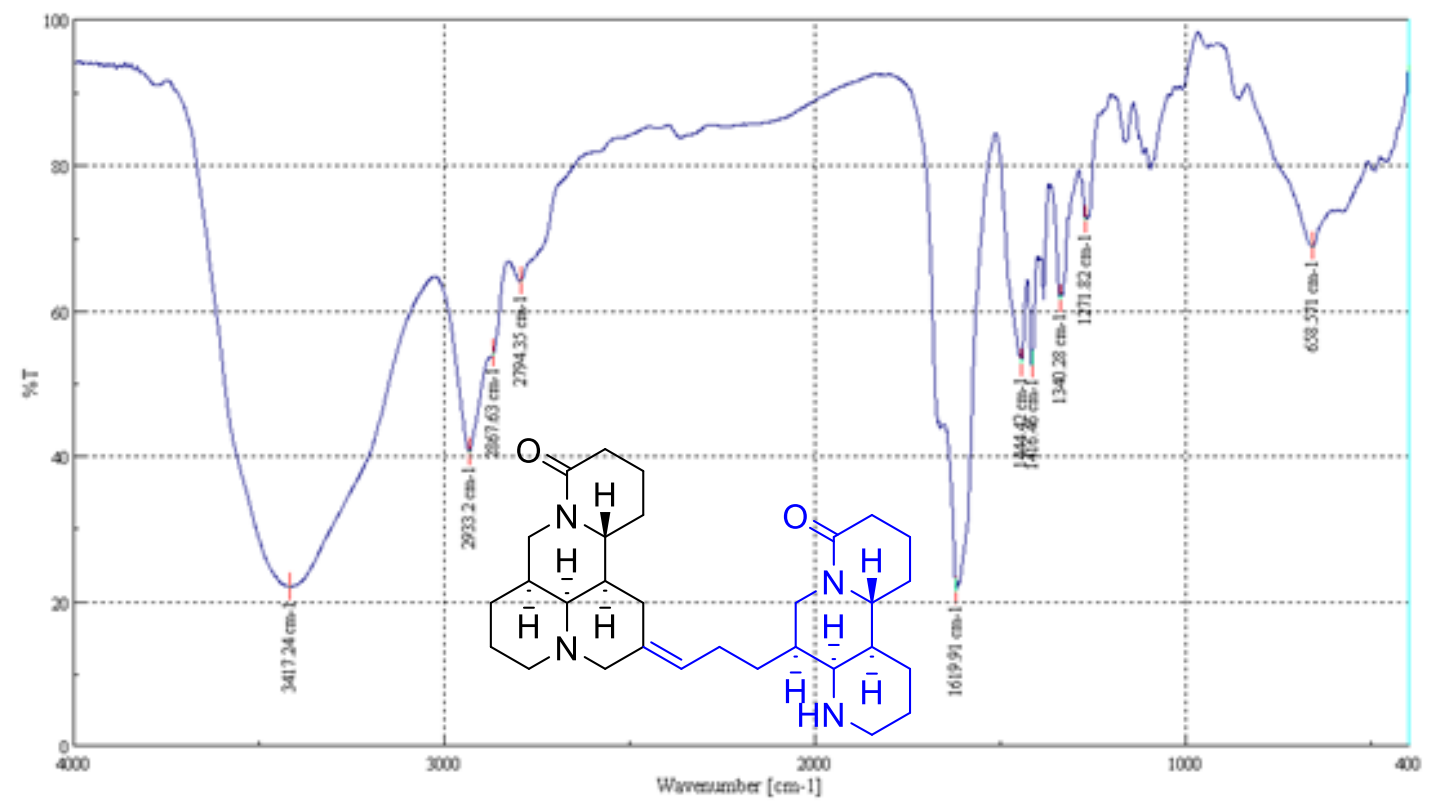

Figure S25. IR spectrum of 3 (KBr disc)

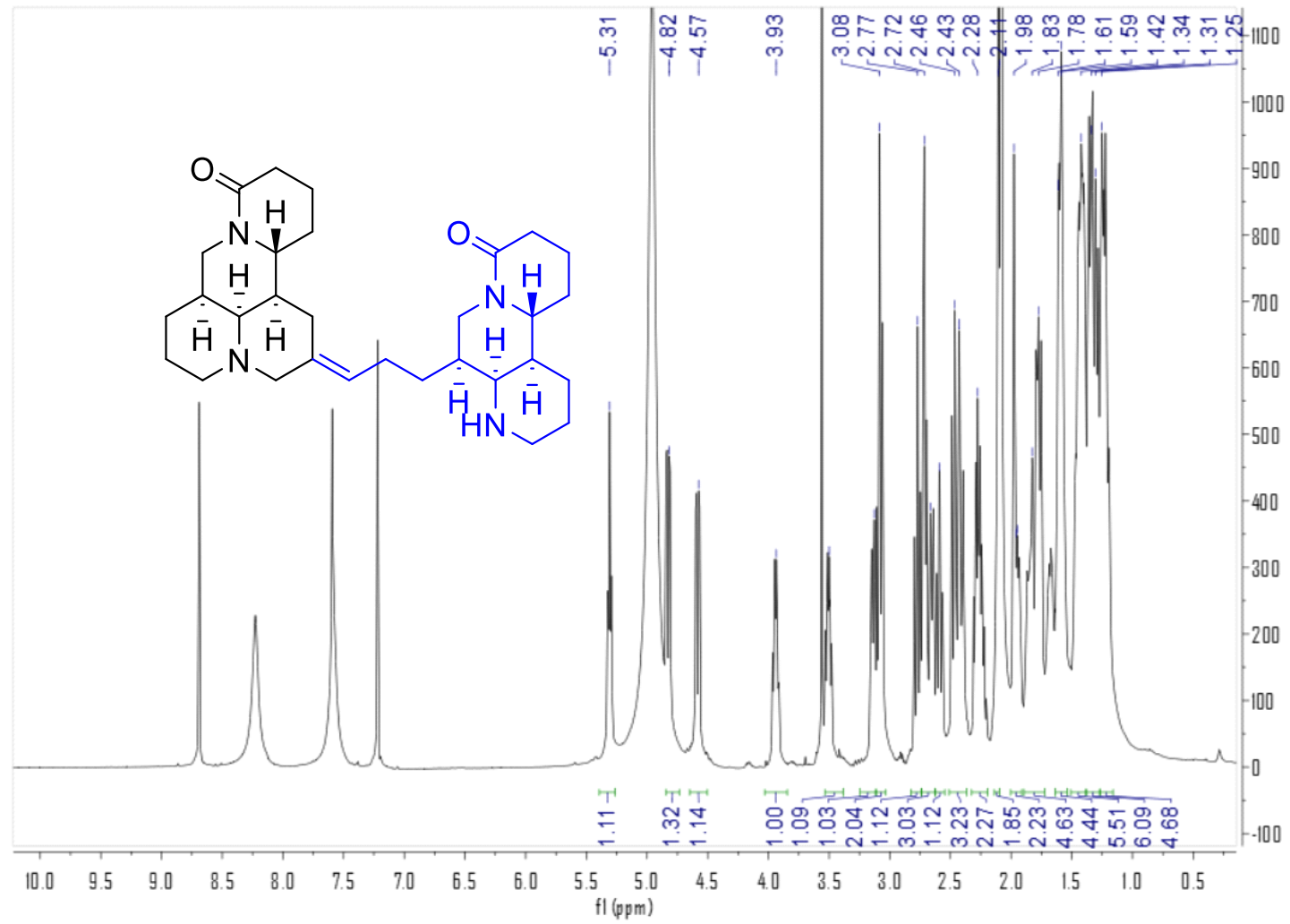

Figure S26. ${ }^{1} \mathrm{H}$ NMR spectrum of 3 in $\mathrm{C}_{5} \mathrm{D}_{5} \mathrm{~N}$ 


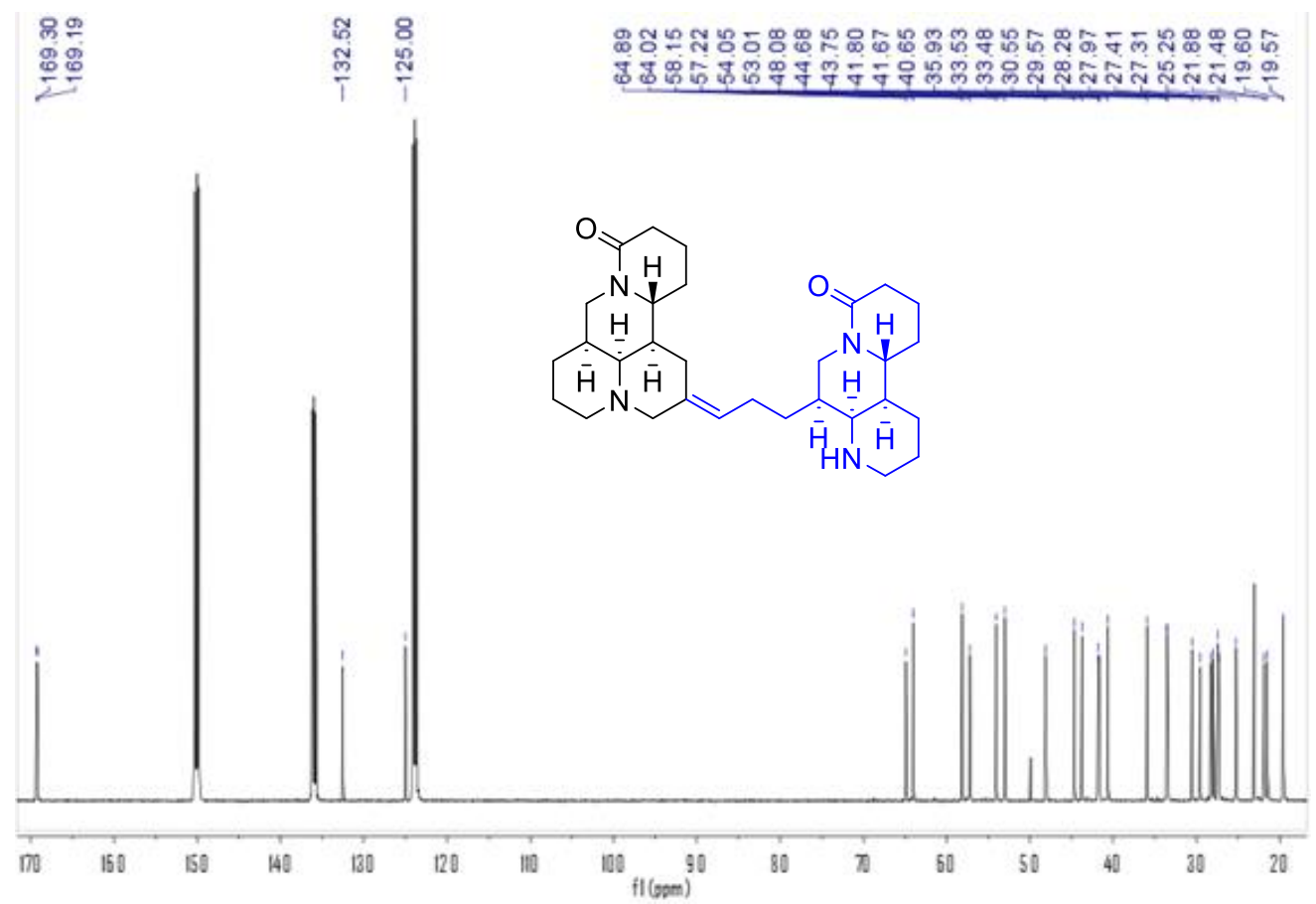

Figure S27. ${ }^{13} \mathrm{C}$ NMR spectrum of 3 in $\mathrm{C}_{5} \mathrm{D}_{5} \mathrm{~N}$

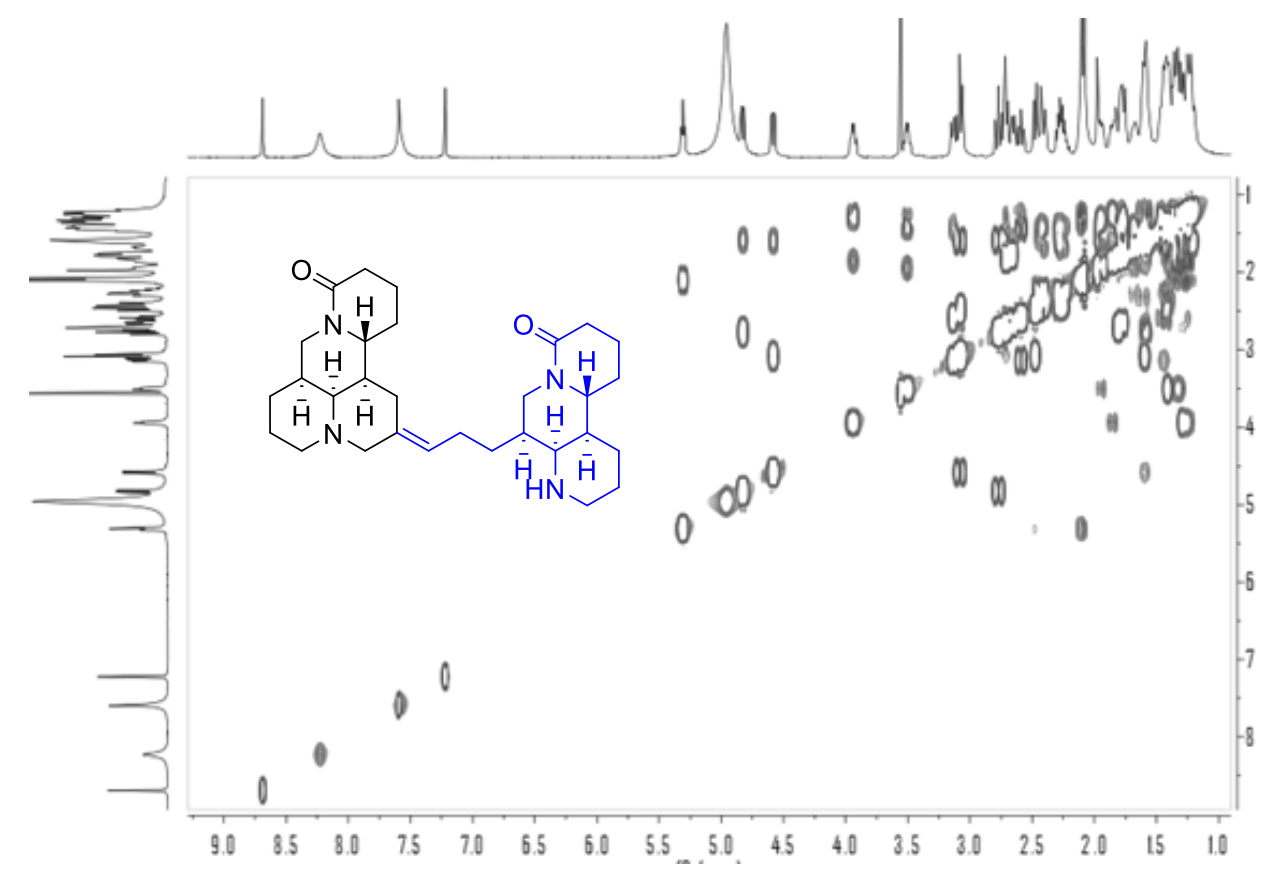

Figure S28. ${ }^{1} \mathrm{H}-{ }^{1} \mathrm{H}$ COSY spectrum of 3 in $\mathrm{C}_{5} \mathrm{D}_{5} \mathrm{~N}$ 


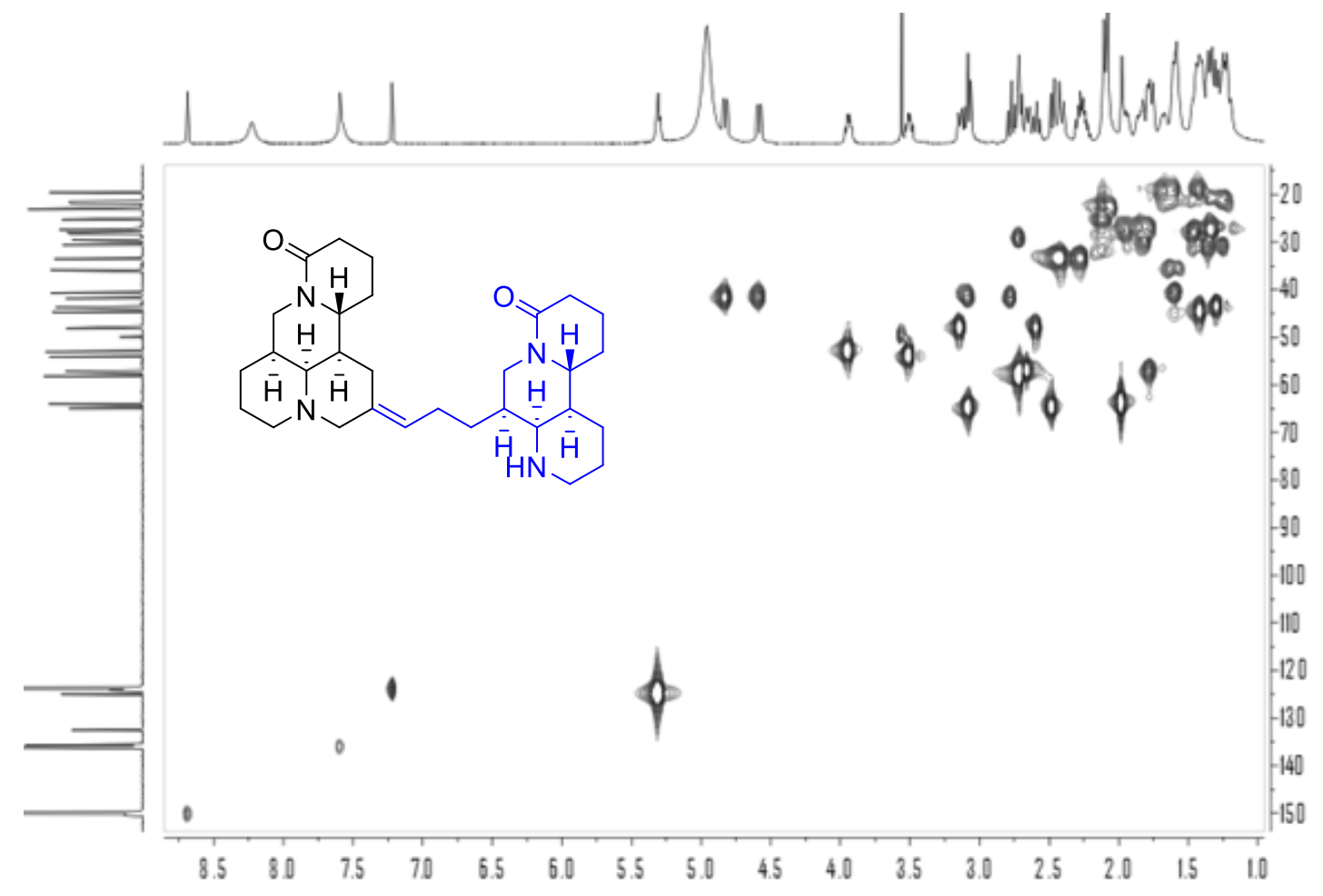

Figure S29. HSQC spectrum of 3 in $C_{5} D_{5} N$

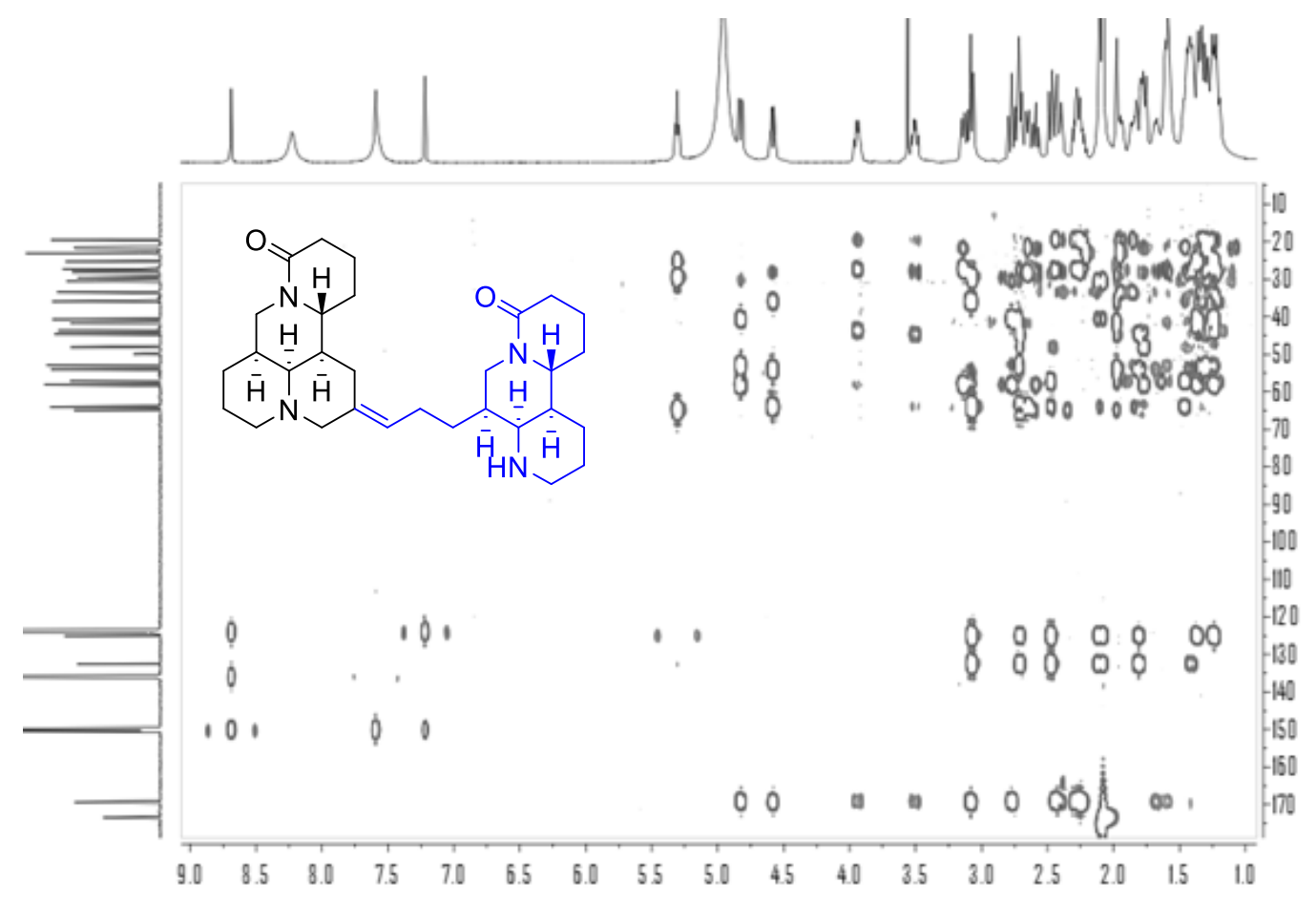

Figure S30. HMBC spectrum of 3 in $C_{5} D_{5} N$ 


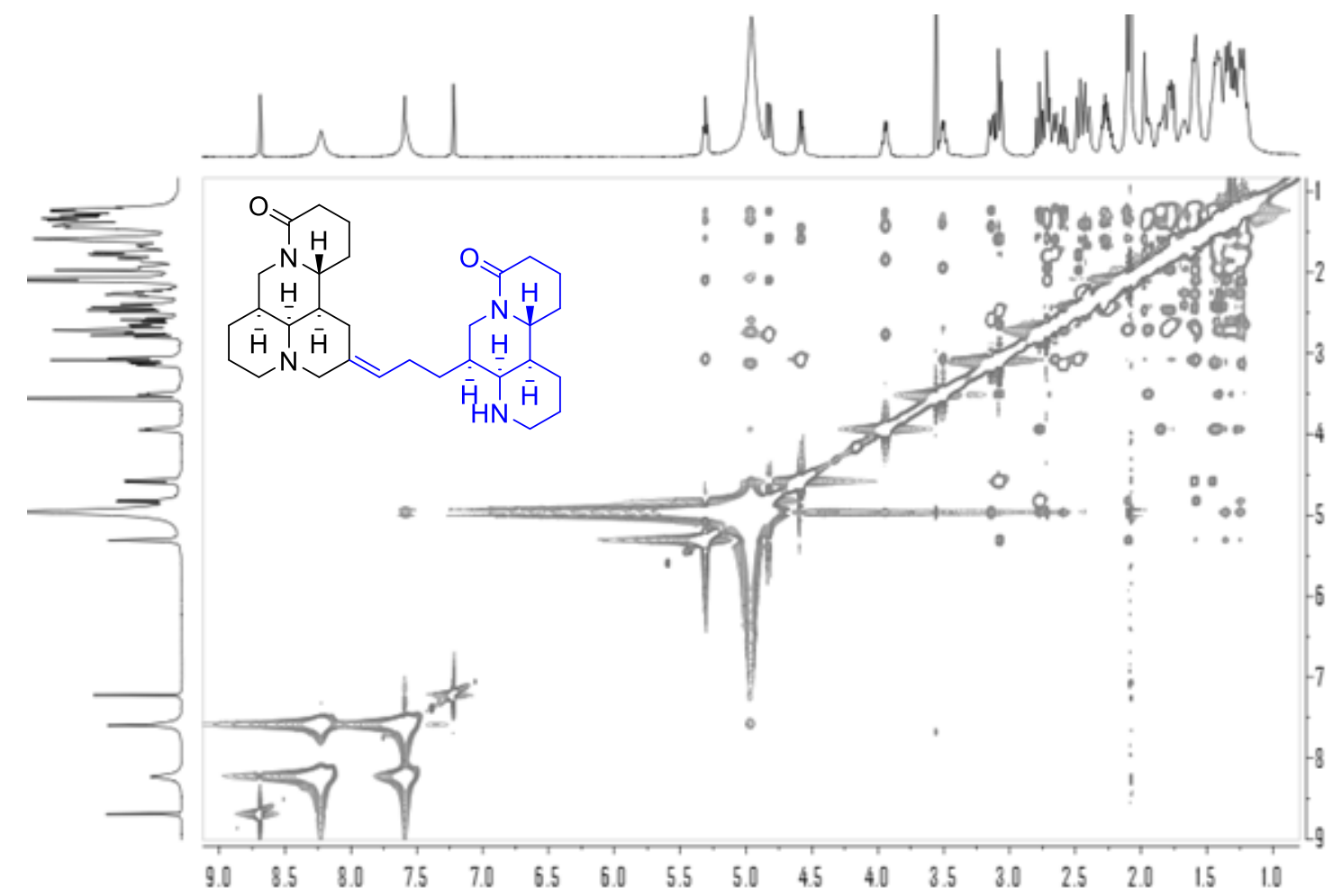

Figure S31. ROESY spectrum of 3 in $C_{5} D_{5} N$

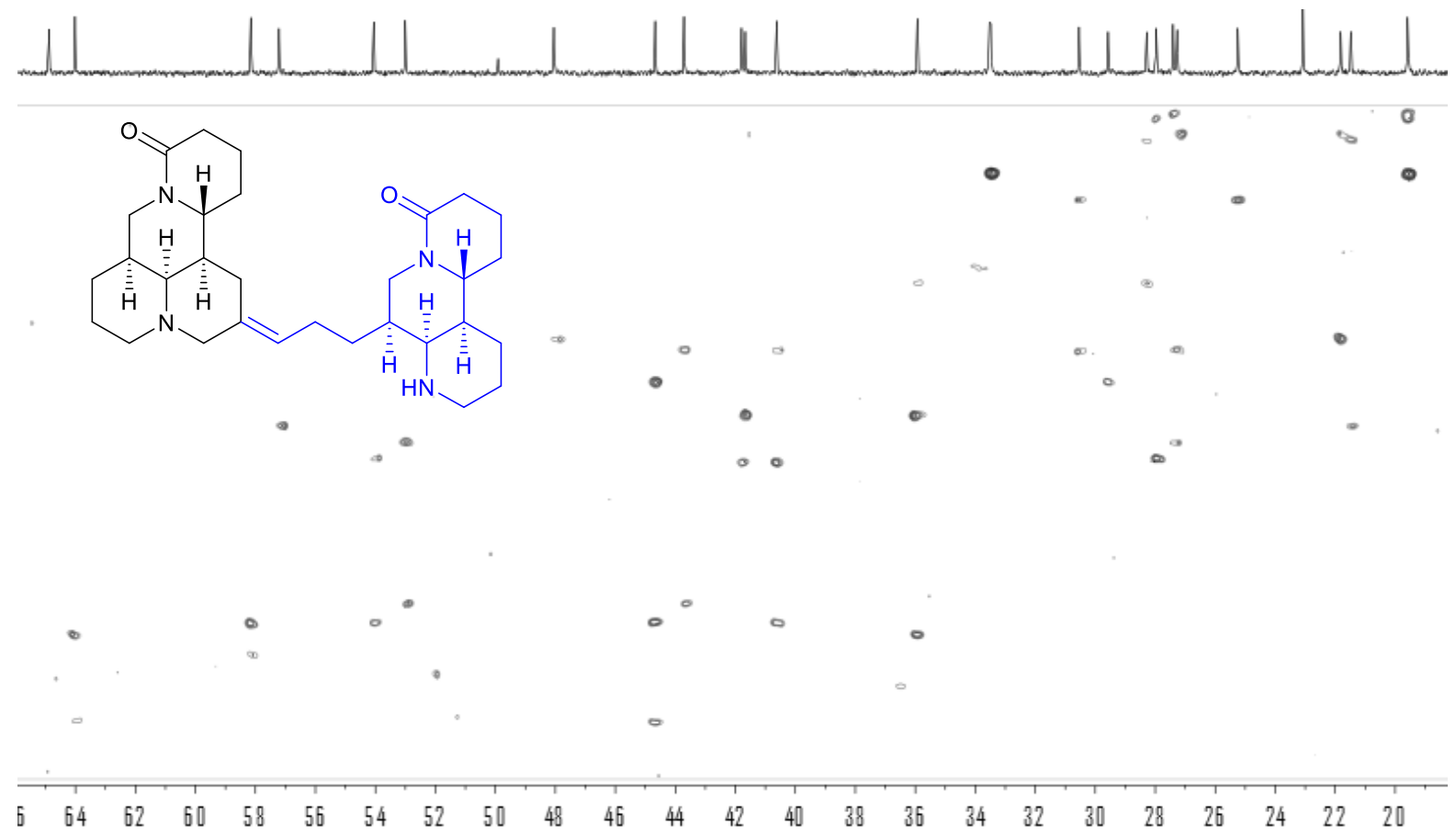

Figure S32. 2D INADEQUATE spectrum of 3 in $C_{5} D_{5} N$ 


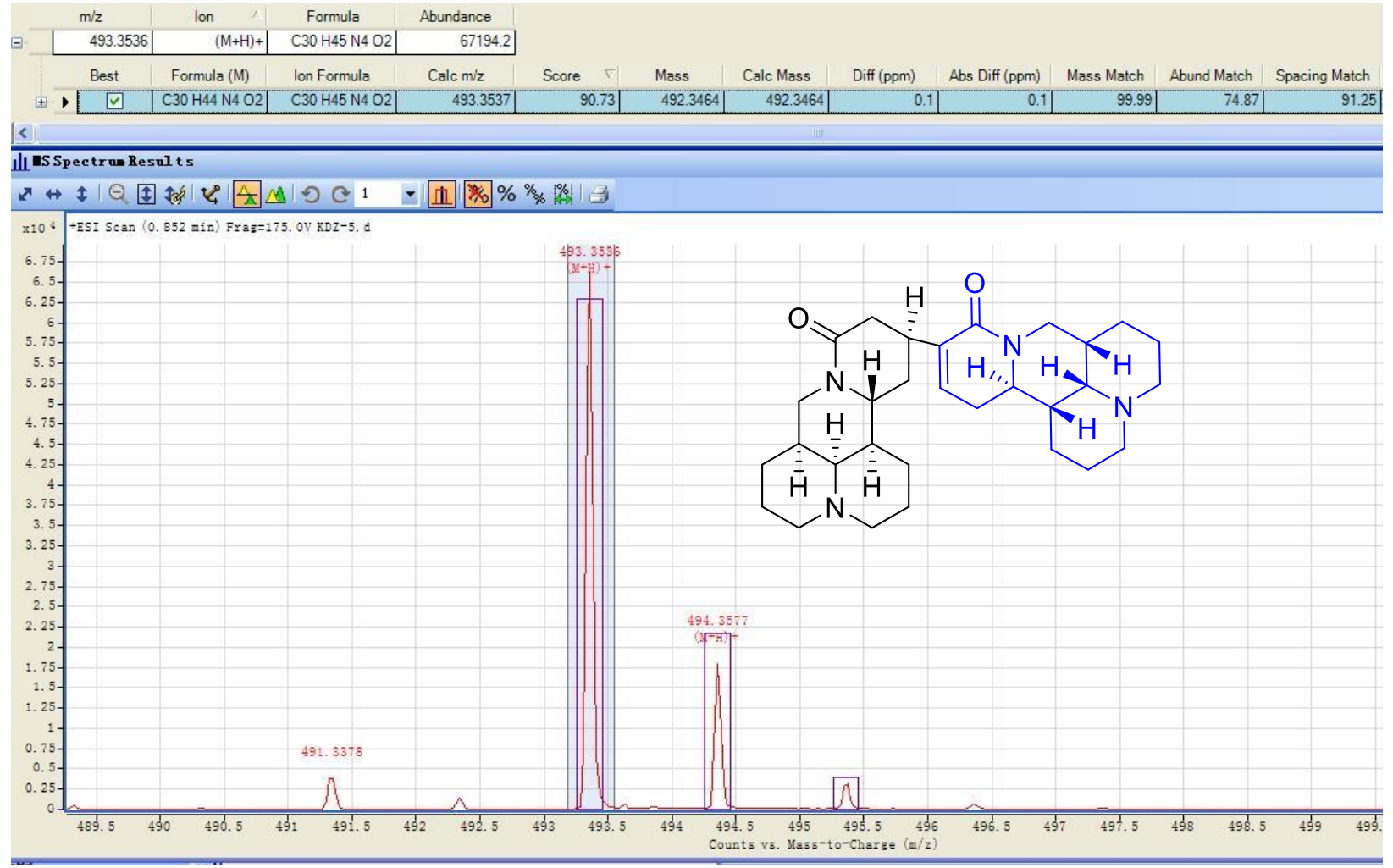

Figure S33. HR-ESI-MS spectrum of 4

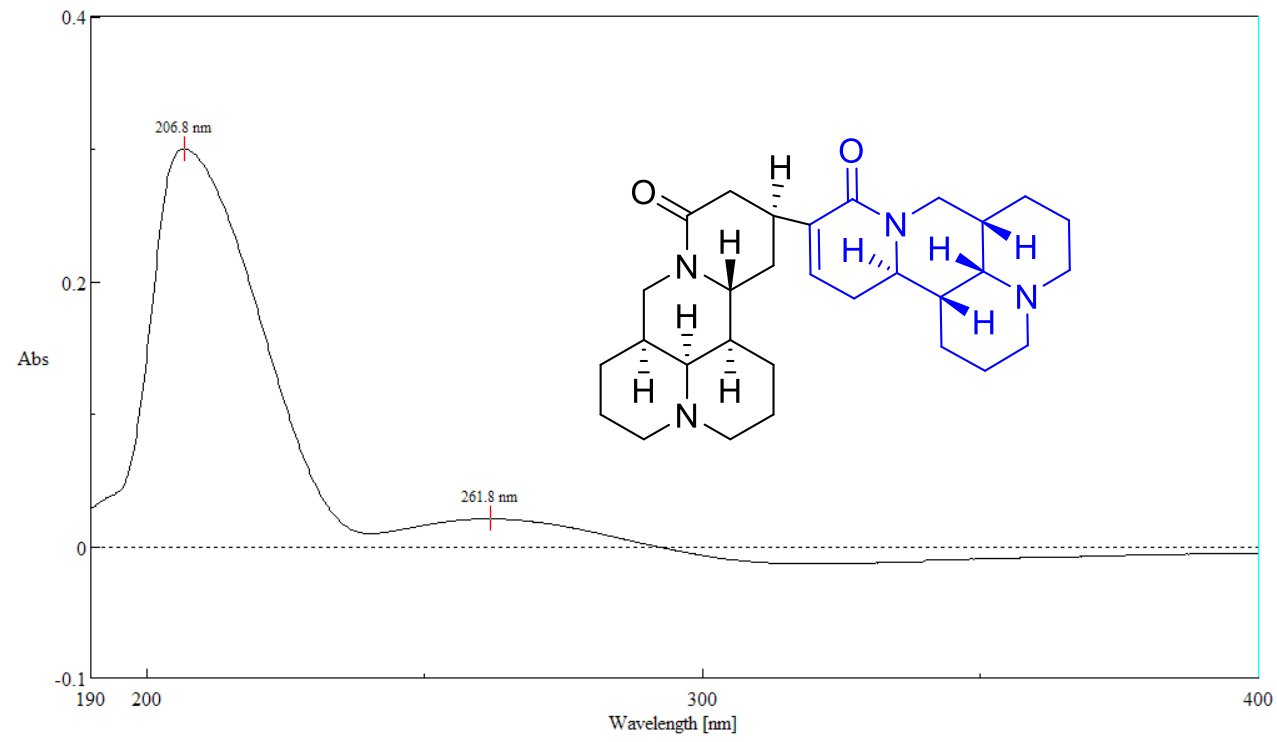

Figure S34. UV spectrum of $4\left(\mathrm{CH}_{3} \mathrm{OH}\right)$ 


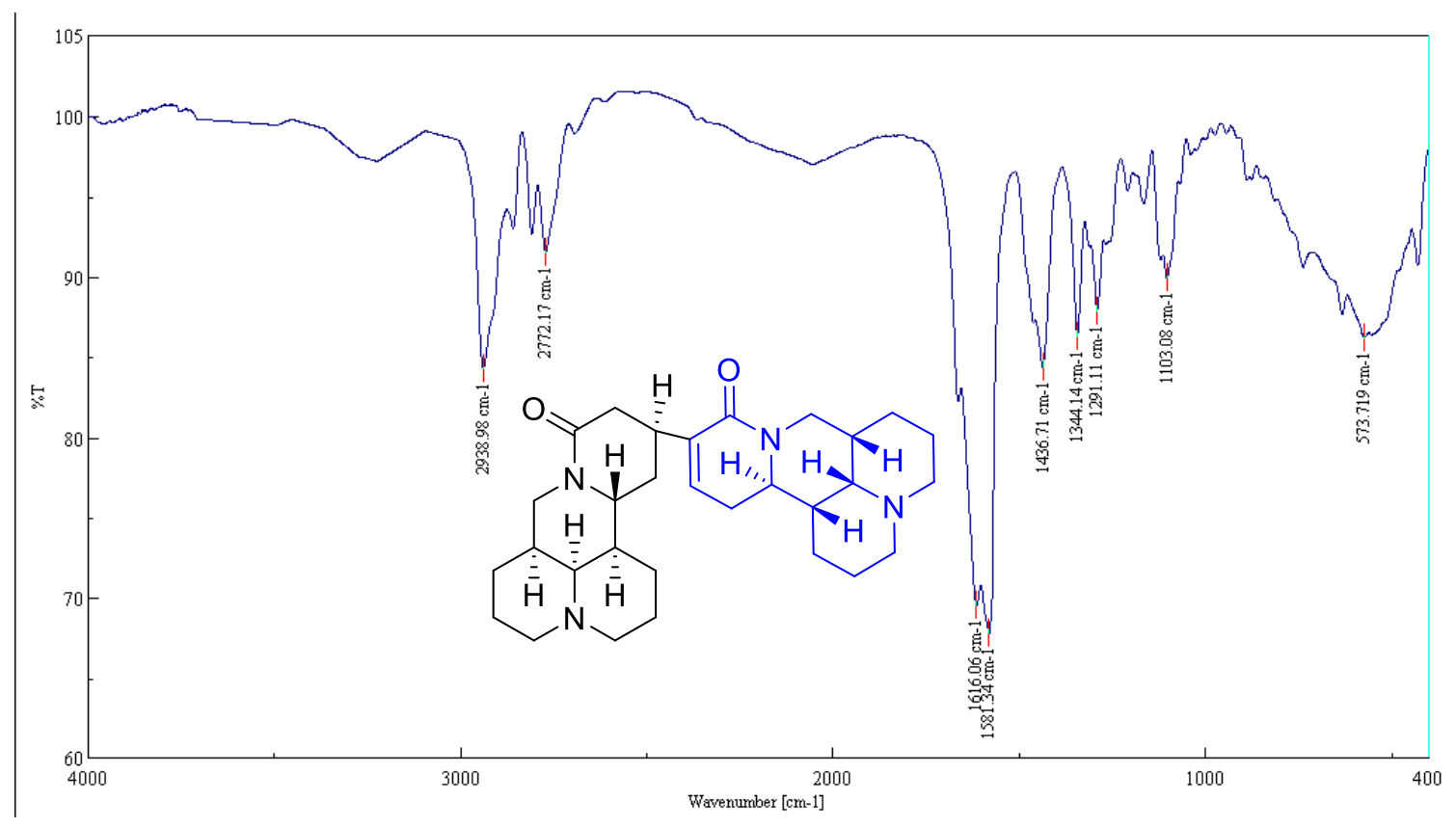

Figure S35. IR spectrum of 4 (KBr disc)

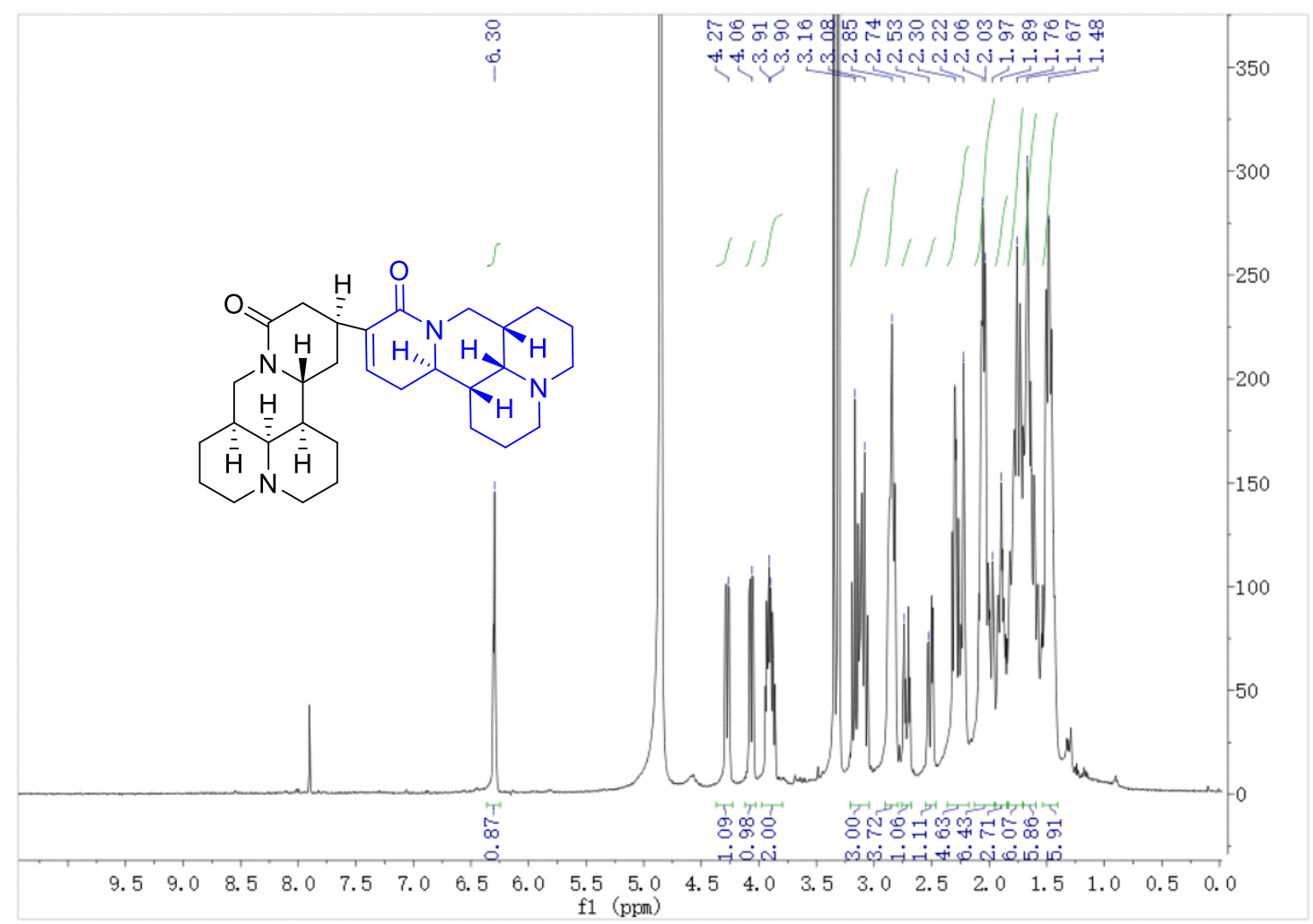

Figure S36. ${ }^{1} \mathrm{H}$ NMR spectrum of 4 in $\mathrm{CD}_{3} \mathrm{OD}$ 


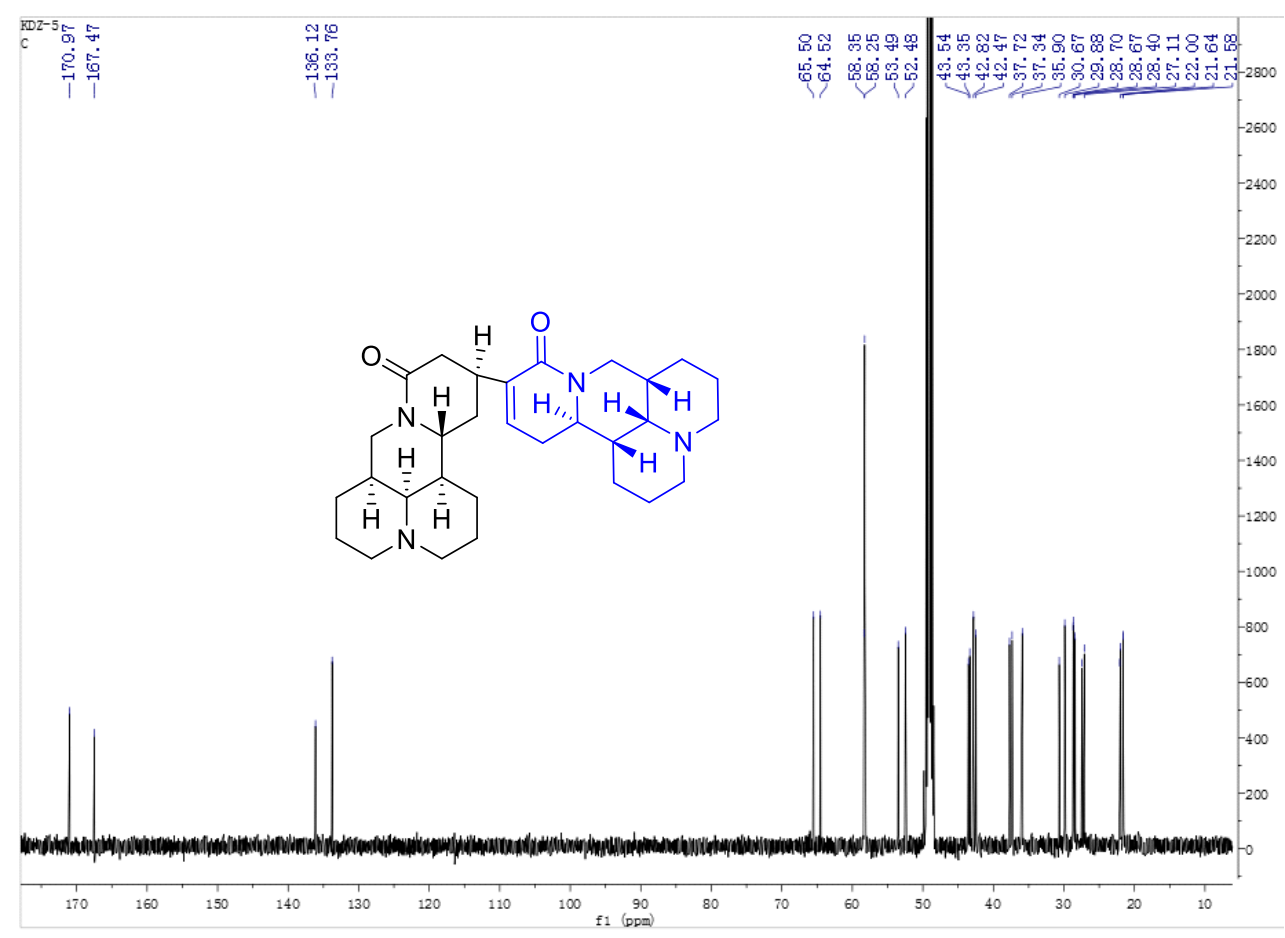

Figure S37. ${ }^{13} \mathrm{C}$ NMR spectrum of 4 in $\mathrm{CD}_{3} \mathrm{OD}$

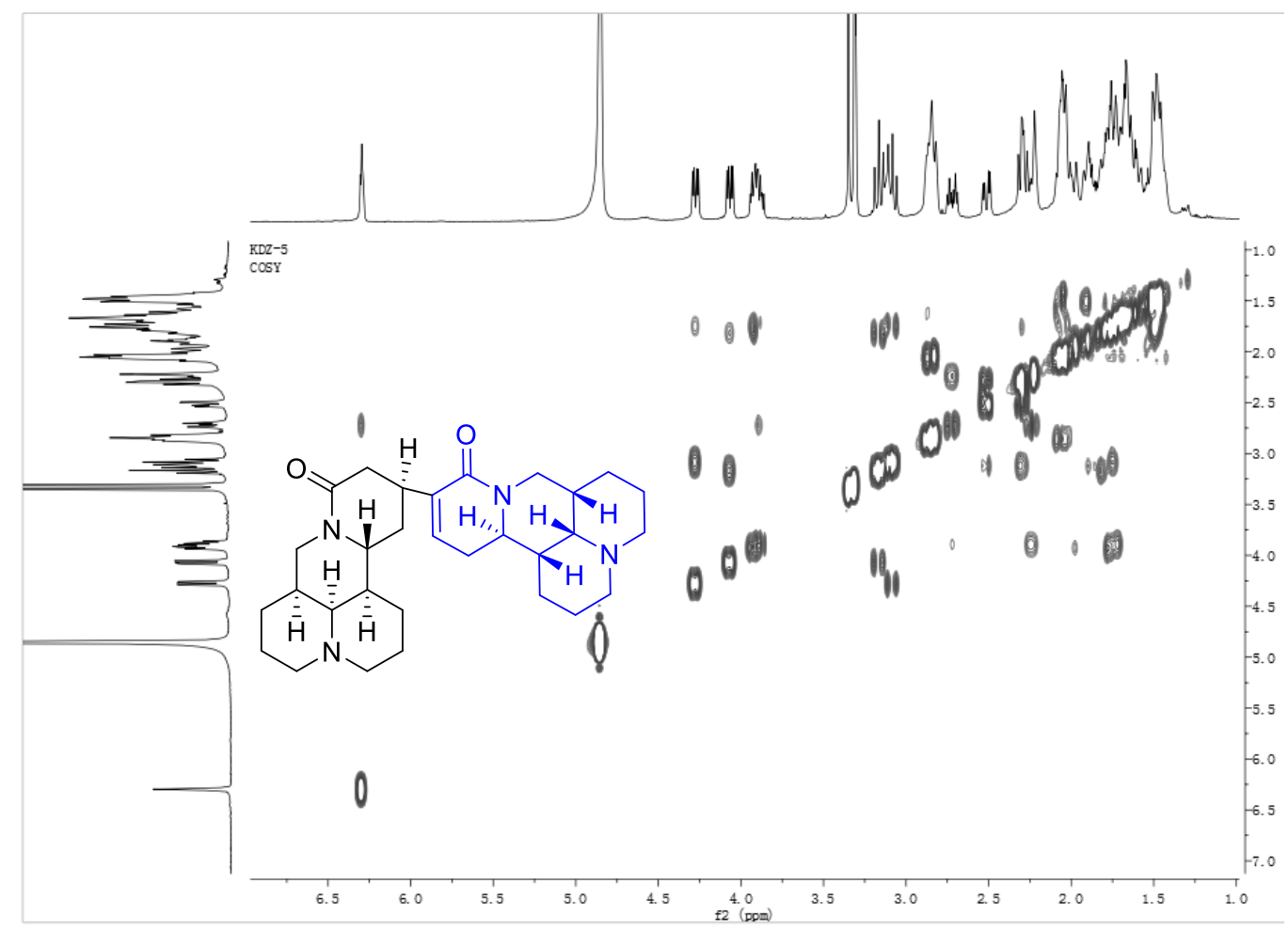

Figure S38. ${ }^{1} \mathrm{H}-{ }^{1} \mathrm{H}$ COSY spectrum of 4 in $\mathrm{CD}_{3} \mathrm{OD}$ 


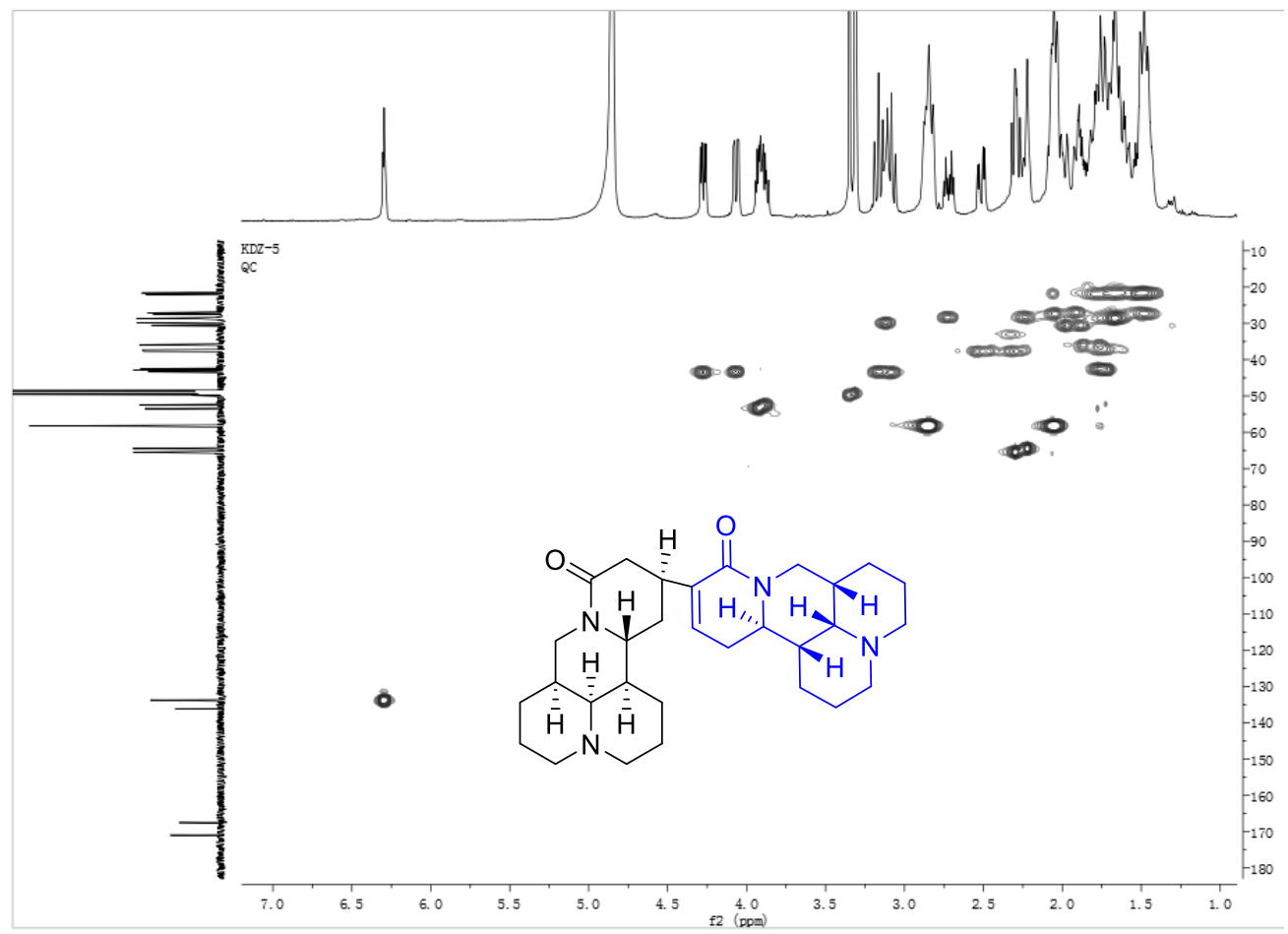

Figure S39. HSQC spectrum of 4 in $\mathrm{CD}_{3} \mathrm{OD}$

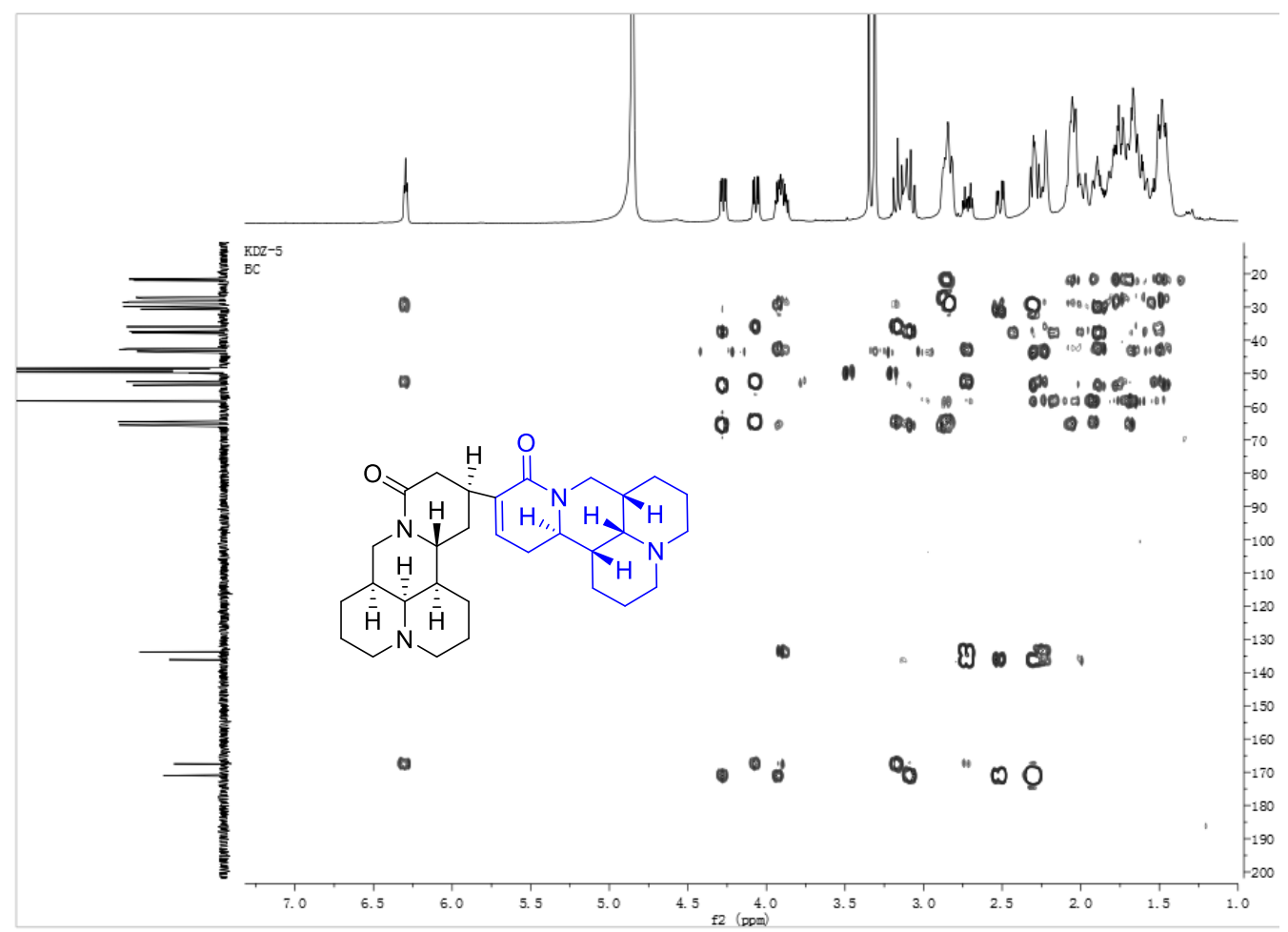

Figure $\mathrm{S40}$. $\mathrm{HMBC}$ spectrum of 4 in $\mathrm{CD}_{3} \mathrm{OD}$ 


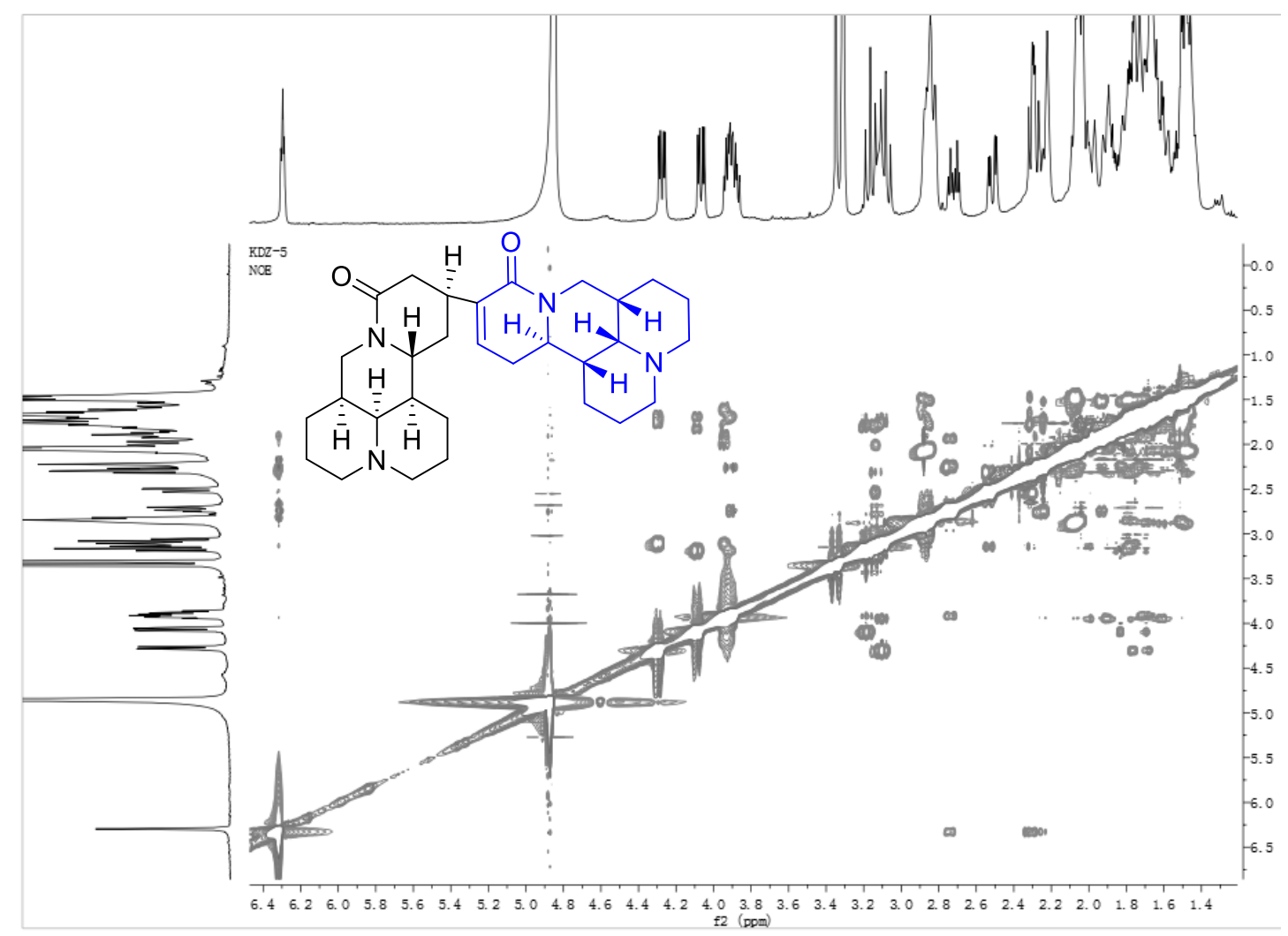

Figure S41. ROESY spectrum of 4 in $\mathrm{CD}_{3} \mathrm{OD}$ 


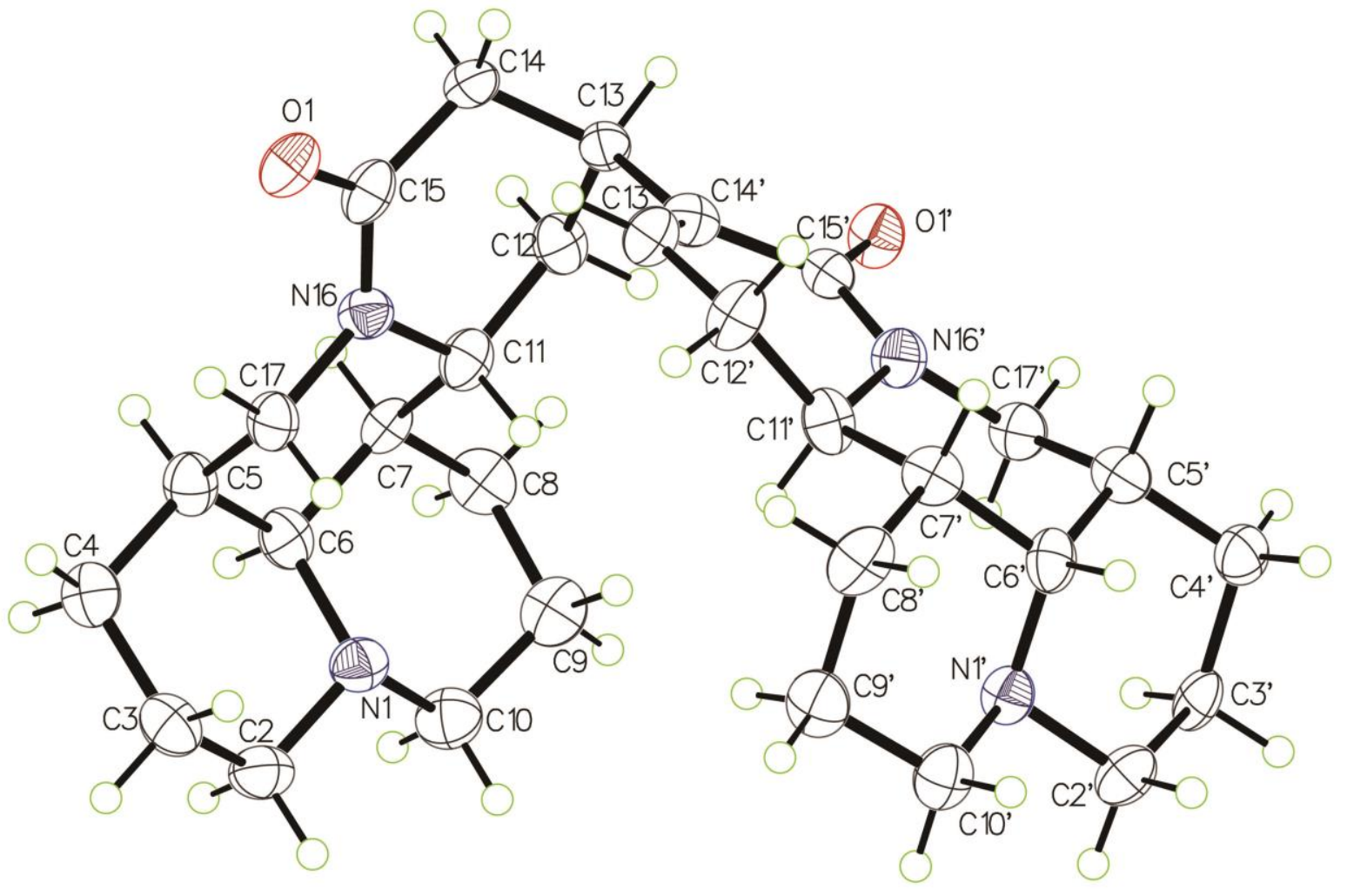

Figure S42. X-ray ORTEP drawings of 4. The thermal ellipsoids are scaled to the $50 \%$ probability level 


\section{X-ray crystallographic data of 4}

Empirical formula

Formula weight

Temperature/K

Crystal system

Space group

$a / \AA$

$b / \AA$

$c / \AA$

$\alpha /^{\circ}$

$\beta /^{\circ}$

$\gamma /{ }^{\circ}$

Volume $/ \AA^{3}$

Z

$\rho_{\text {calc }} \mathrm{g} / \mathrm{cm}^{3}$

$\mu / \mathrm{mm}^{-1}$

$F(000)$

Crystal size $/ \mathrm{mm}^{3}$

Radiation

$2 \Theta$ range for data collection ${ }^{\circ}$

Index ranges

Reflections collected

Independent reflections

Data/restraints/parameters

Goodness-of-fit on $\mathrm{F}^{2}$

Final R indexes $[\mathrm{I}>=2 \sigma(\mathrm{I})]$

Final $\mathrm{R}$ indexes [all data]

Largest diff. peak/hole / e $\AA^{-3}$

Flack parameter
$\mathrm{C}_{30} \mathrm{H}_{44} \mathrm{~N}_{4} \mathrm{O}_{2}$

492.69

173

monoclinic

$P 2_{1}$

12.7119(2)

$8.40898(14)$

$15.2657(3)$

90.00

98.5861(17)

90.00

$1613.53(5)$

2

1.014

0.499

536.0

$0.32 \times 0.26 \times 0.24$

$\mathrm{CuK} \alpha(\lambda=1.54184)$

7.032 to 125.412

$-14 \leq \mathrm{h} \leq 14,-9 \leq \mathrm{k} \leq 9,-17 \leq 1 \leq 17$

26060

$5181\left[\mathrm{R}_{\mathrm{int}}=0.0290, \mathrm{R}_{\text {sigma }}=0.0184\right]$

$5181 / 1 / 325$

1.060

$\mathrm{R}_{1}=0.0600, \mathrm{wR}_{2}=0.1487$

$\mathrm{R}_{1}=0.0620, \mathrm{wR}_{2}=0.1507$

$0.56 /-0.23$

$0.50(6)$ 


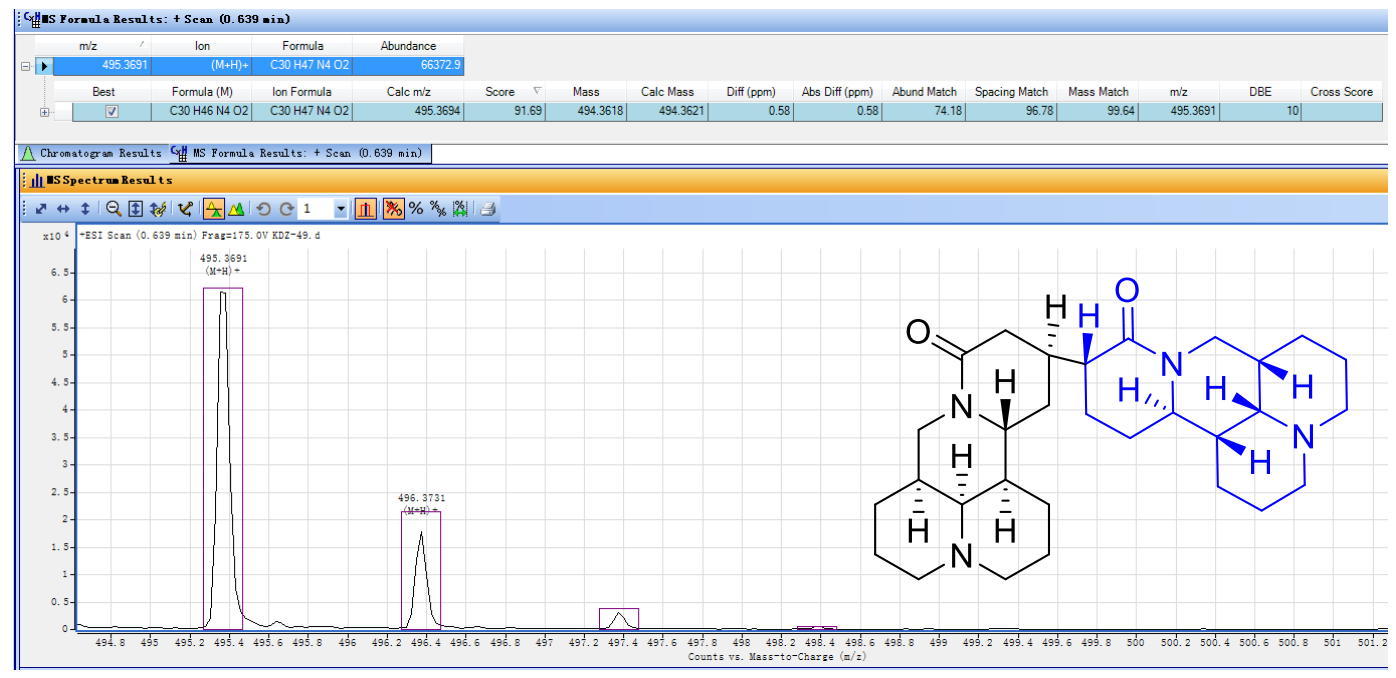

Figure S43. HR-ESI-MS spectrum of 5

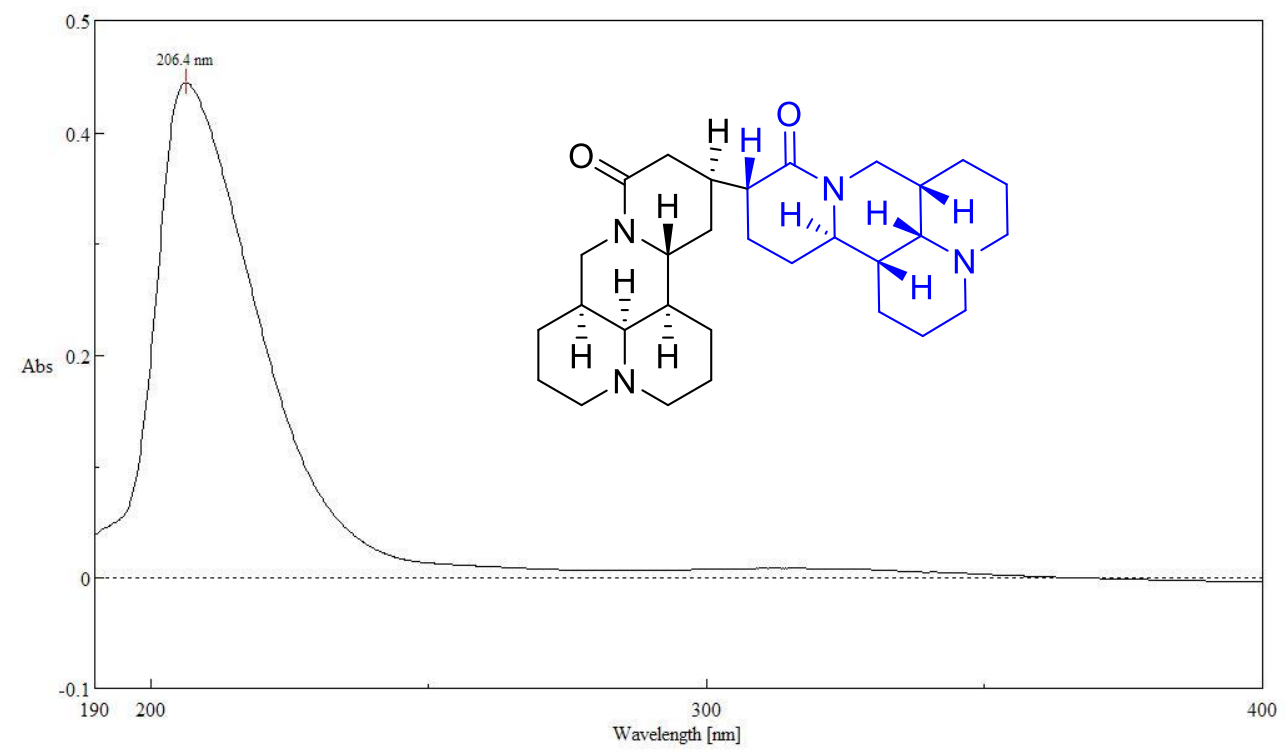

Figure S44. UV spectrum of $5\left(\mathrm{CH}_{3} \mathrm{OH}\right)$ 


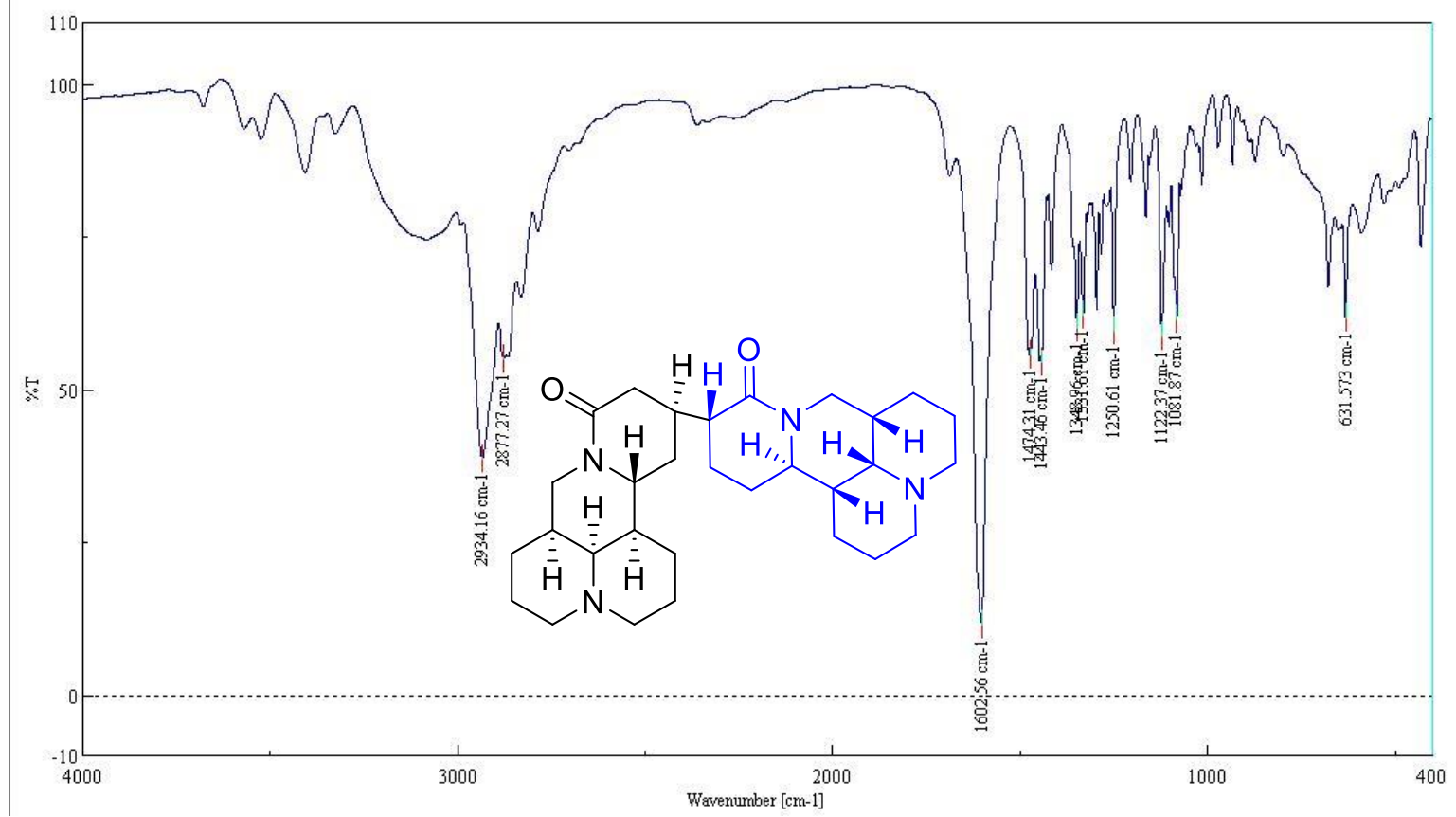

Figure S45. IR spectrum of 5 (KBr disc)

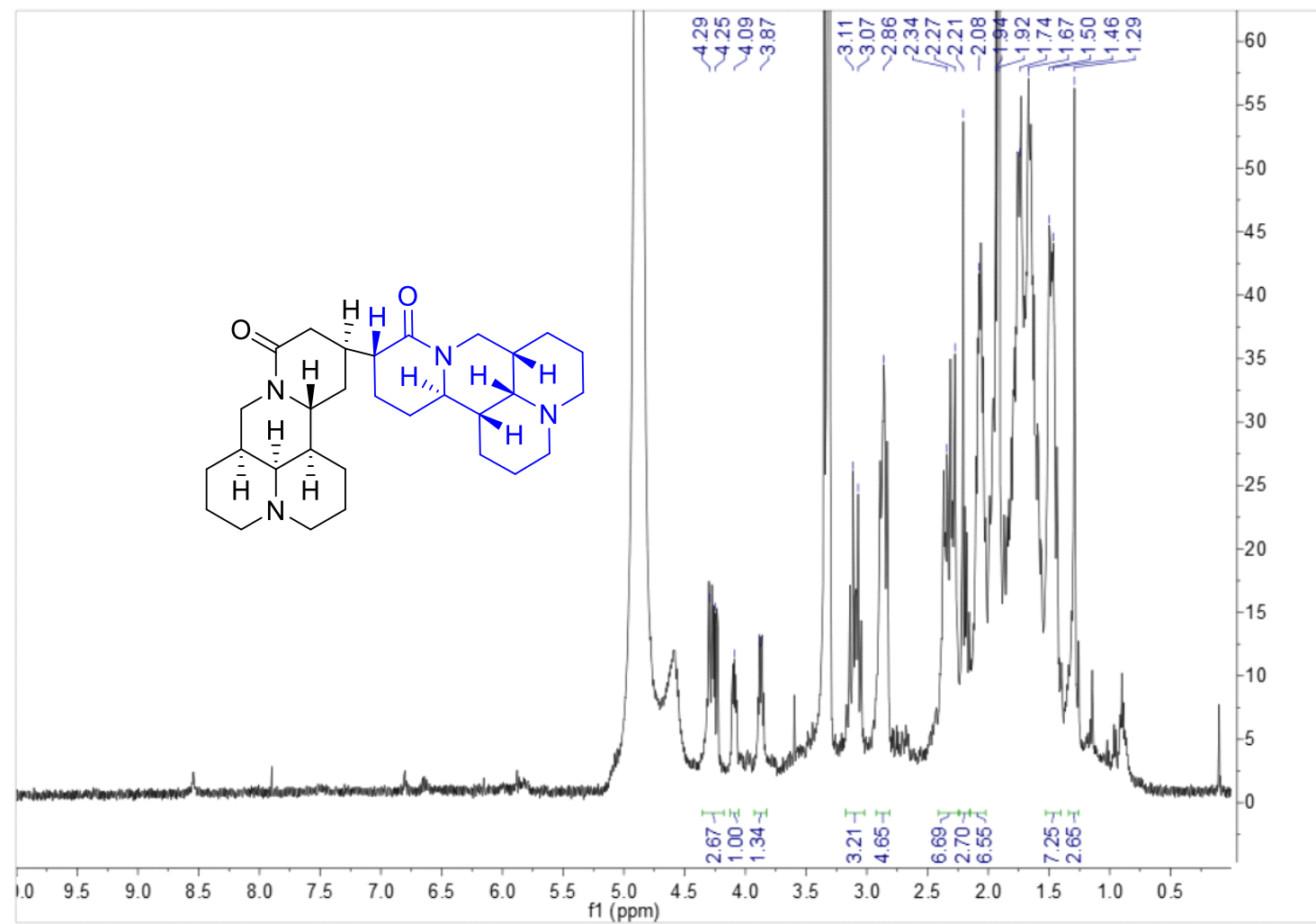

Figure S46. ${ }^{1} \mathrm{H}$ NMR spectrum of 5 in $\mathrm{CD}_{3} \mathrm{OD}$ 


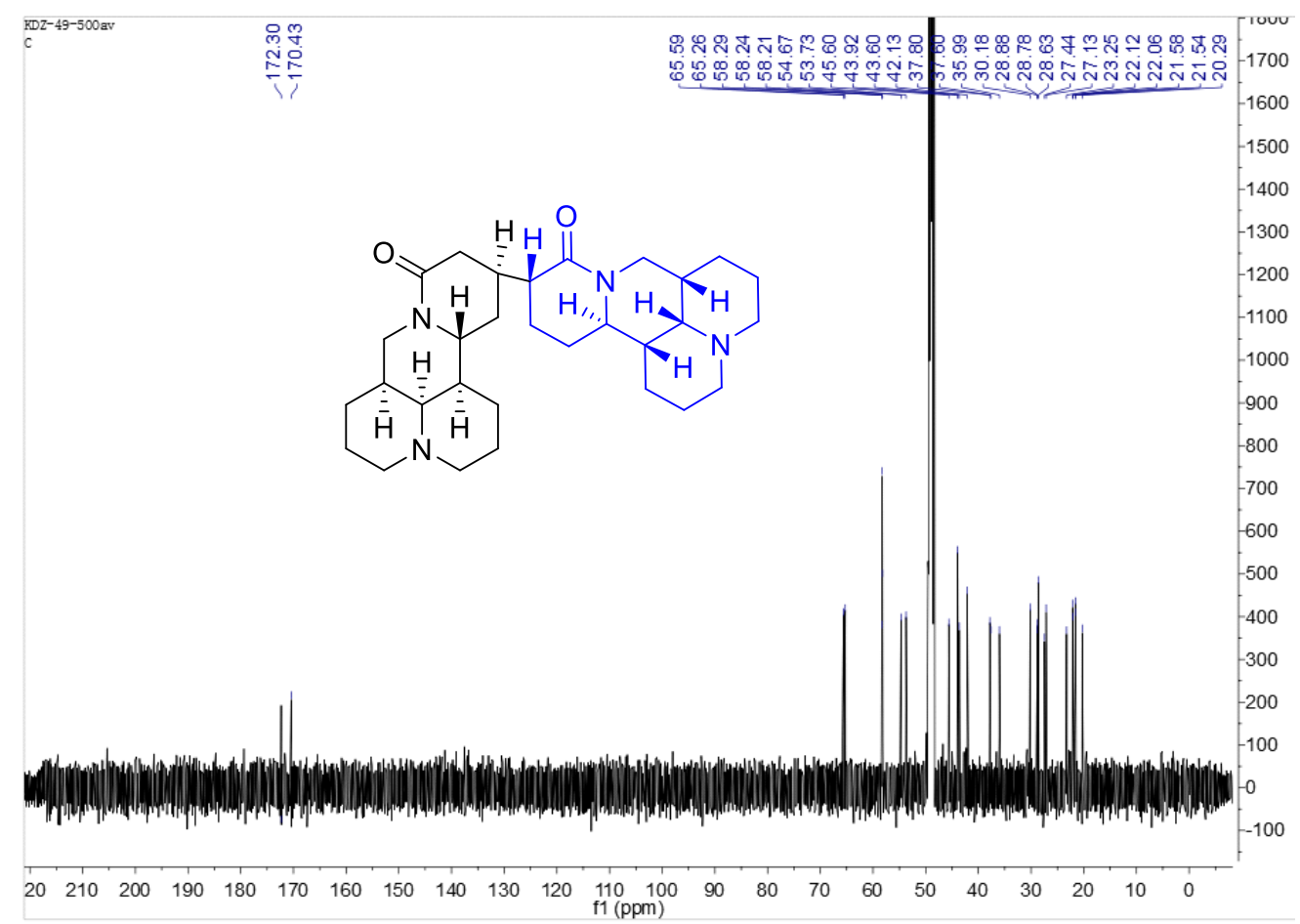

Figure $\mathrm{S47} .{ }^{13} \mathrm{C}$ NMR spectrum of 5 in $\mathrm{CD}_{3} \mathrm{OD}$

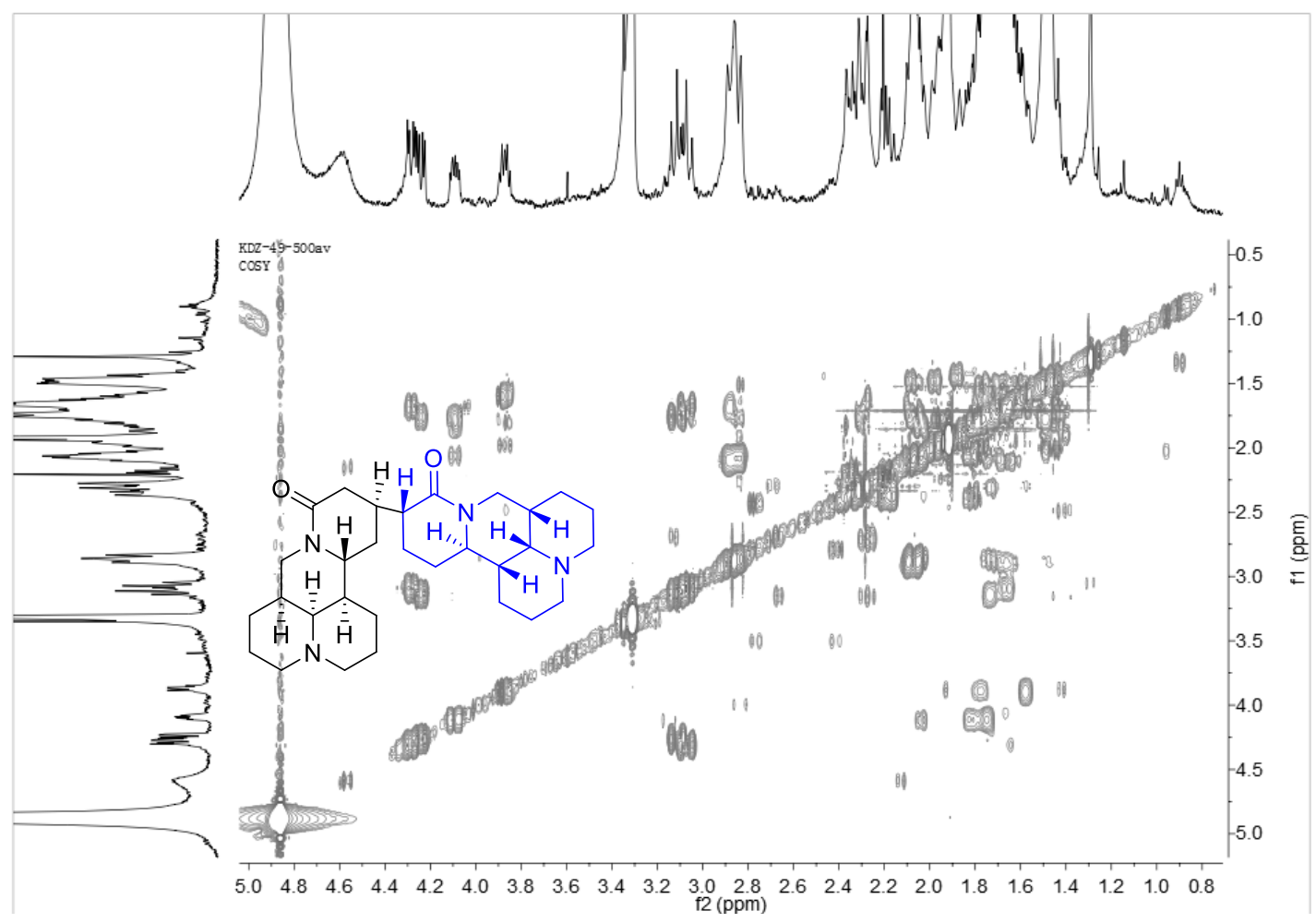

Figure S48. ${ }^{1} \mathrm{H}-{ }^{1} \mathrm{H}$ COSY spectrum of 5 in $\mathrm{CD}_{3} \mathrm{OD}$ 


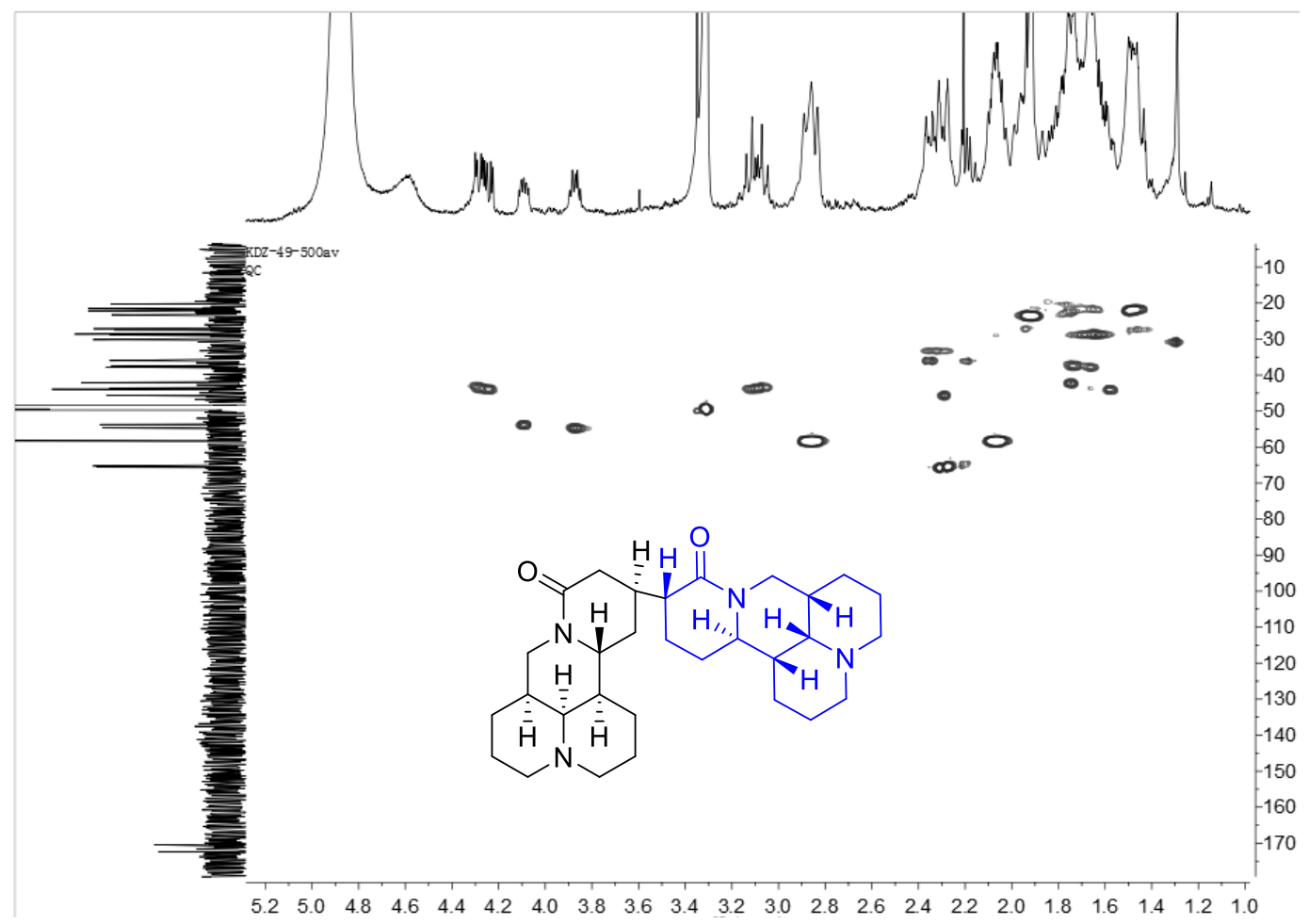

Figure S49. HSQC spectrum of 5 in $\mathrm{CD}_{3} \mathrm{OD}$

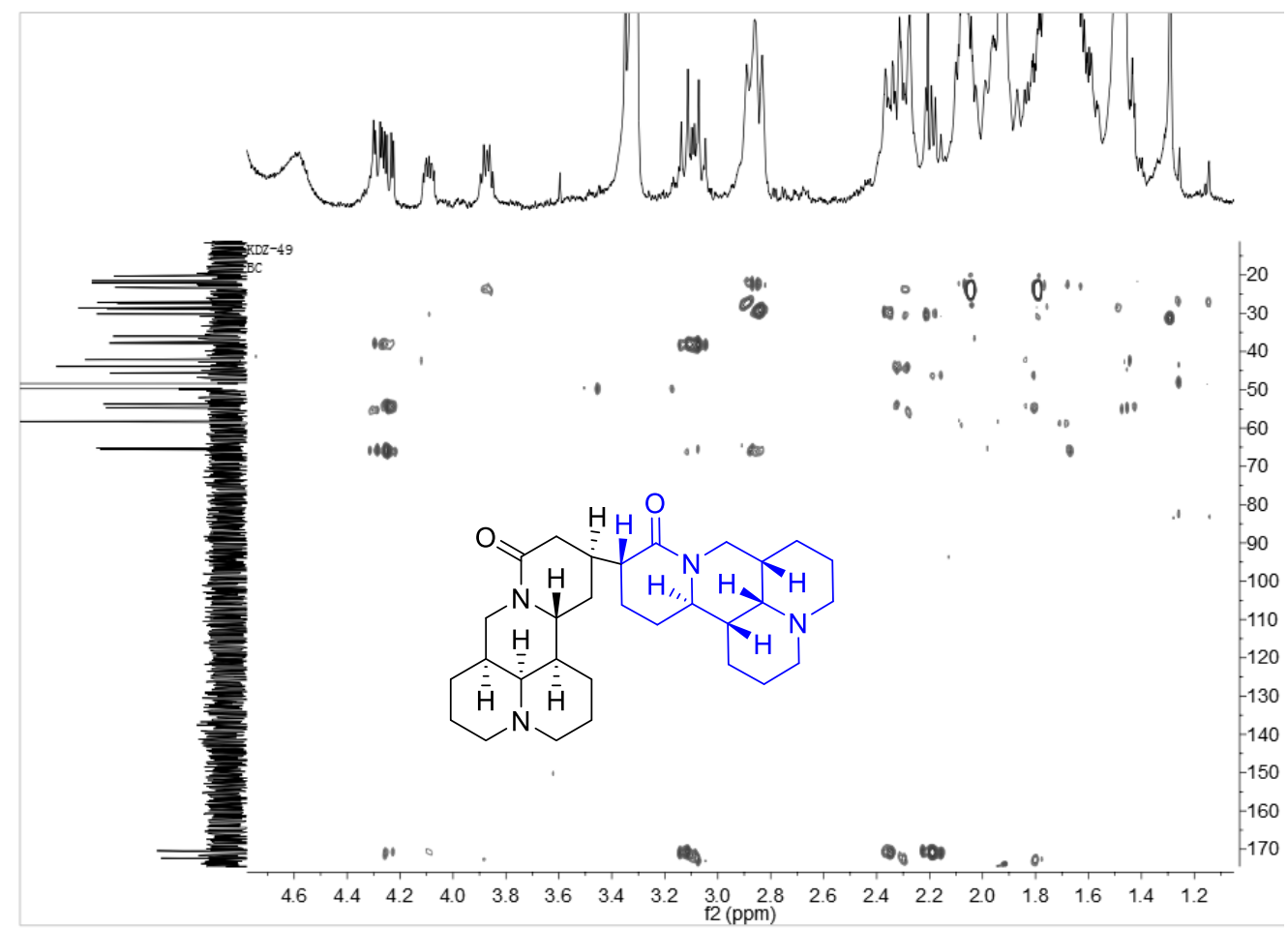

Figure S50. HMBC spectrum of 5 in $\mathrm{CD}_{3} \mathrm{OD}$ 


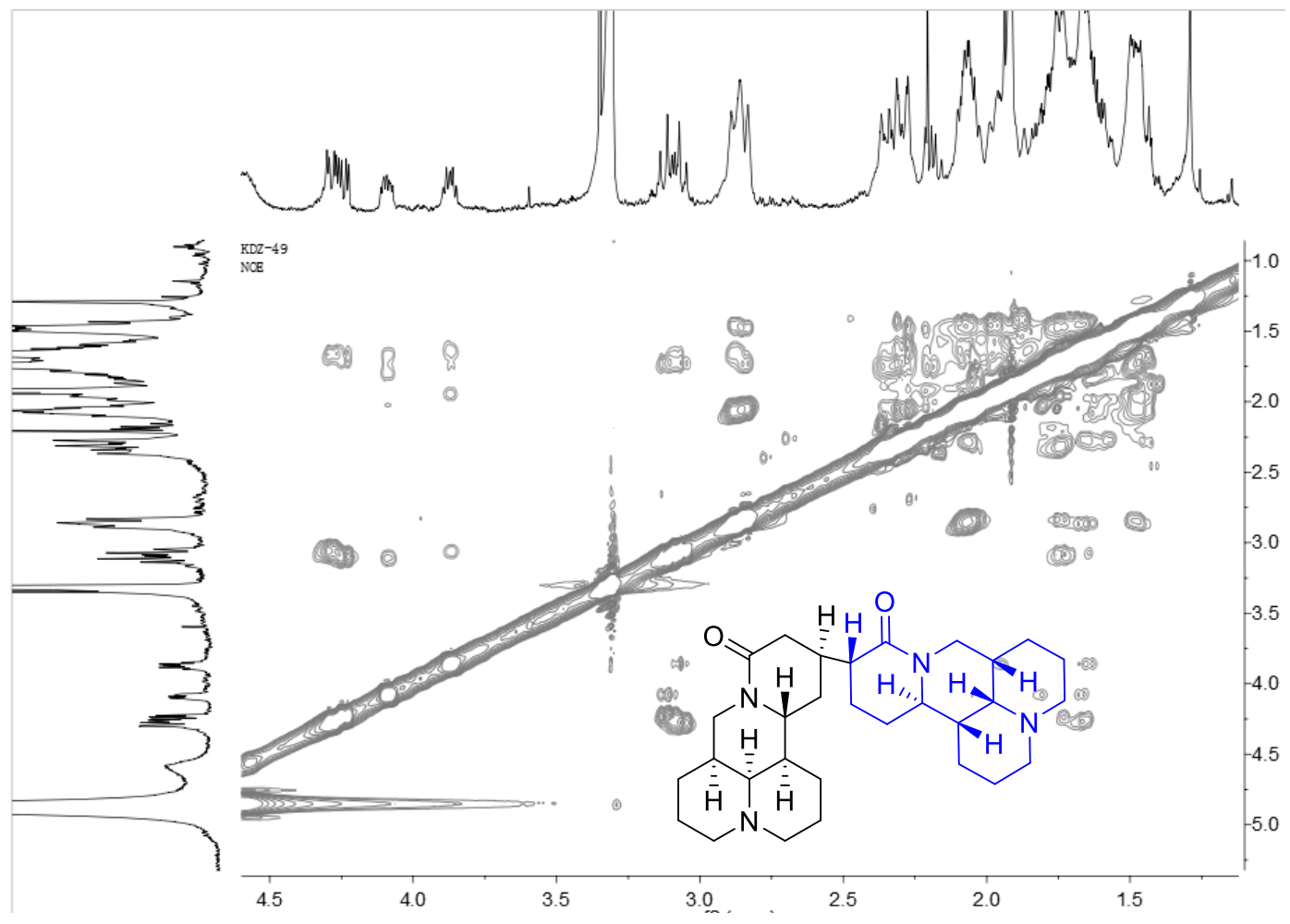

Figure S51. ROESY spectrum of 5 in $\mathrm{CD}_{3} \mathrm{OD}$

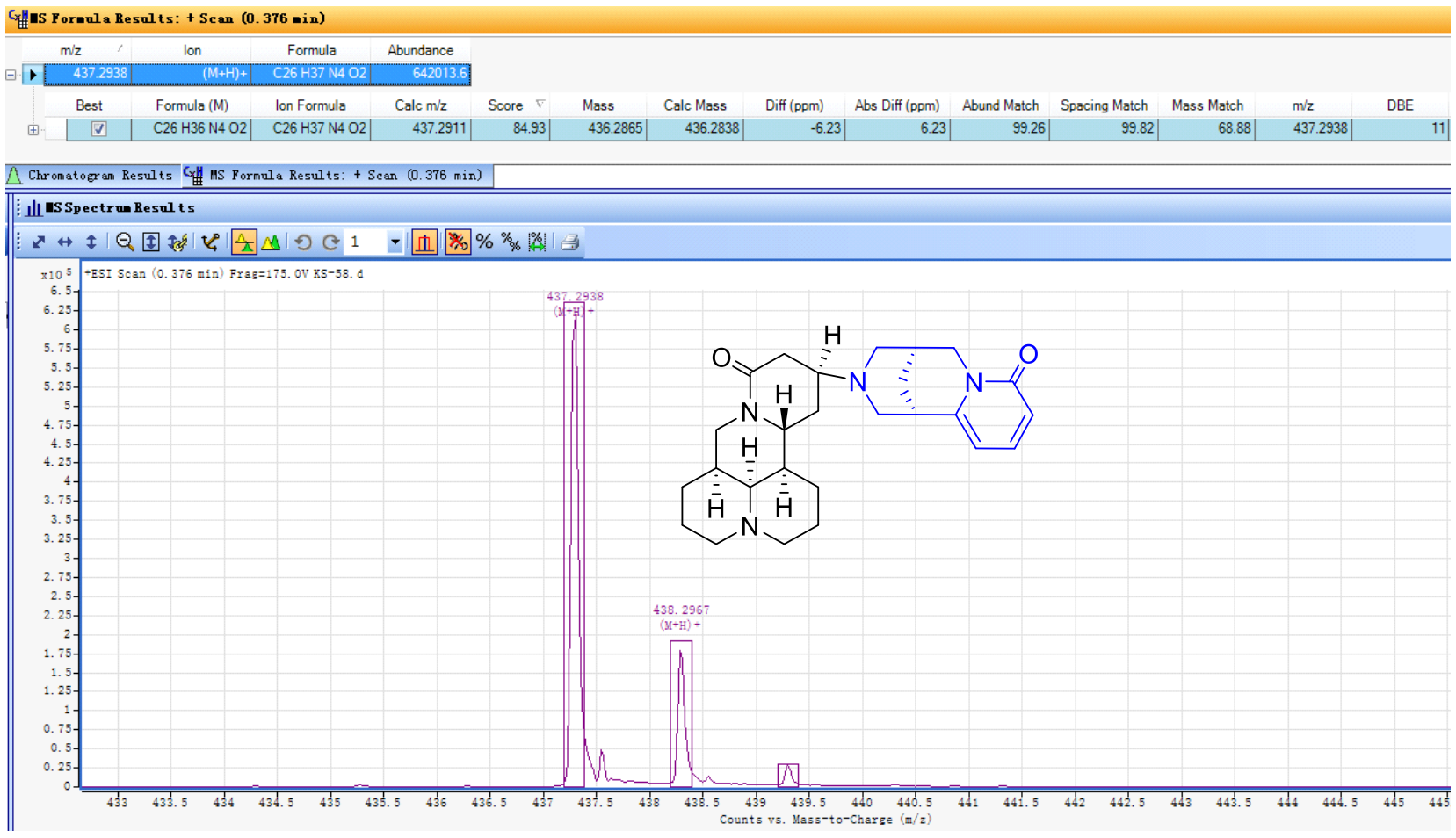

Figure S52. HR-ESI-MS spectrum of 6 


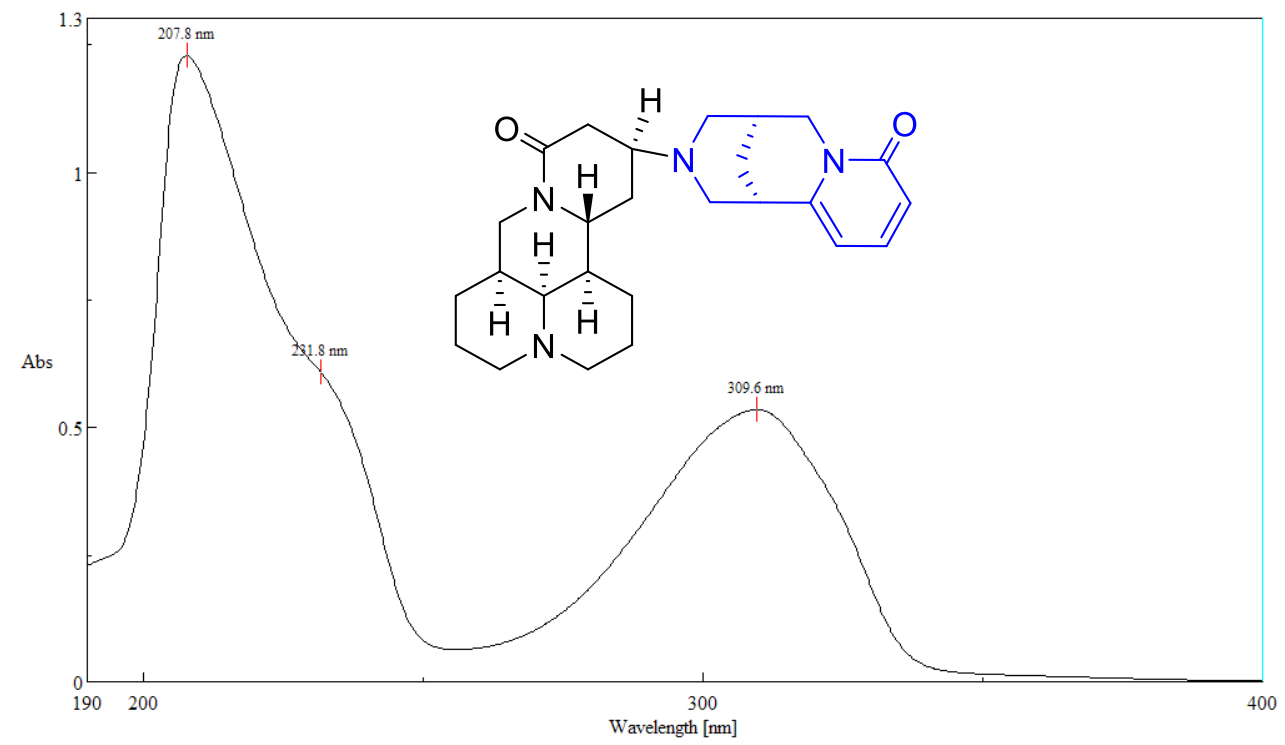

Figure S53. UV spectrum of $6\left(\mathrm{CH}_{3} \mathrm{OH}\right)$

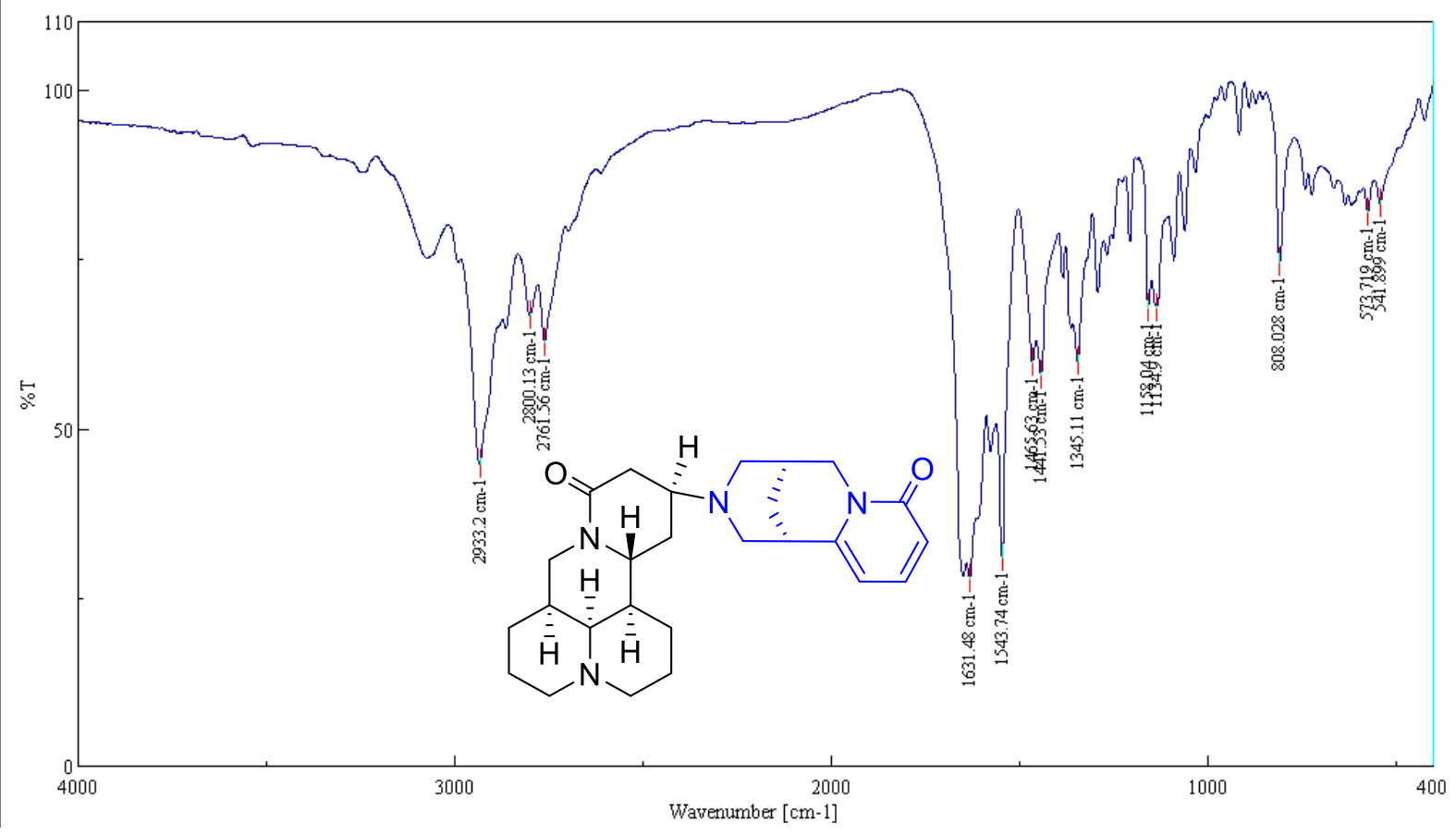

Figure S54. IR spectrum of 6 ( $\mathrm{KBr}$ disc) 


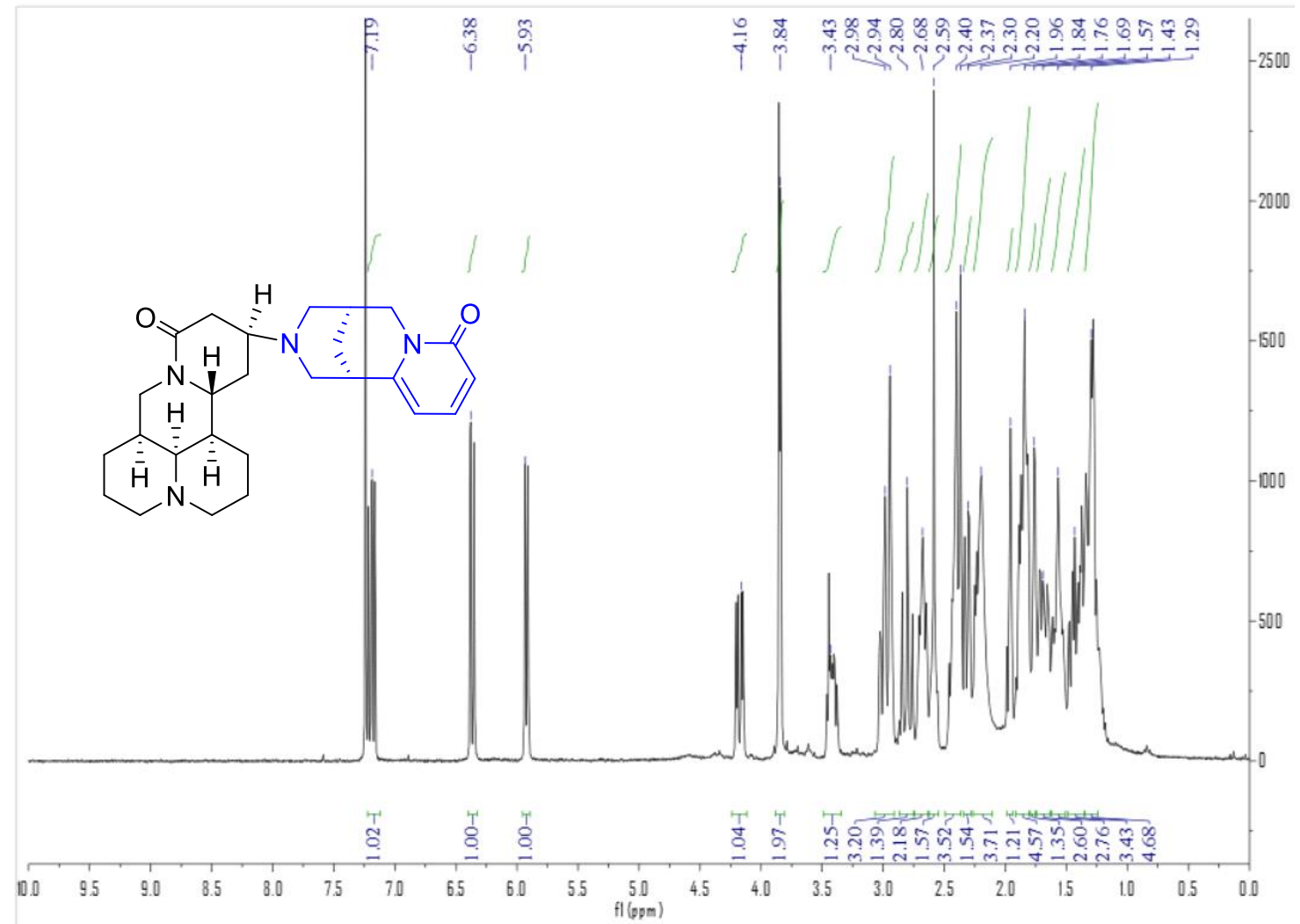

Figure S55. ${ }^{1} \mathrm{H}$ NMR spectrum of 6 in $\mathrm{CDCl}_{3}$

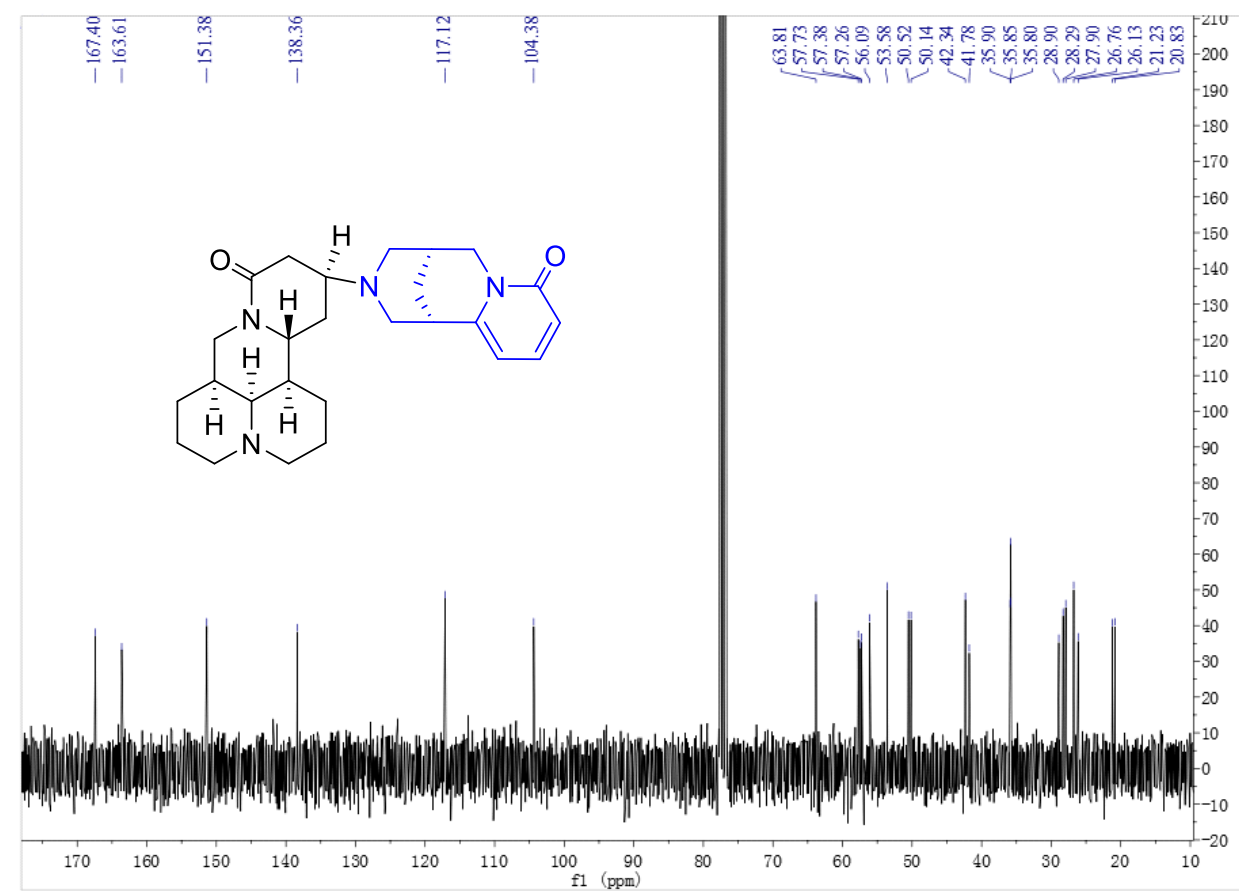

Figure S56. ${ }^{13} \mathrm{C}$ NMR spectrum of 6 in $\mathrm{CDCl}_{3}$ 


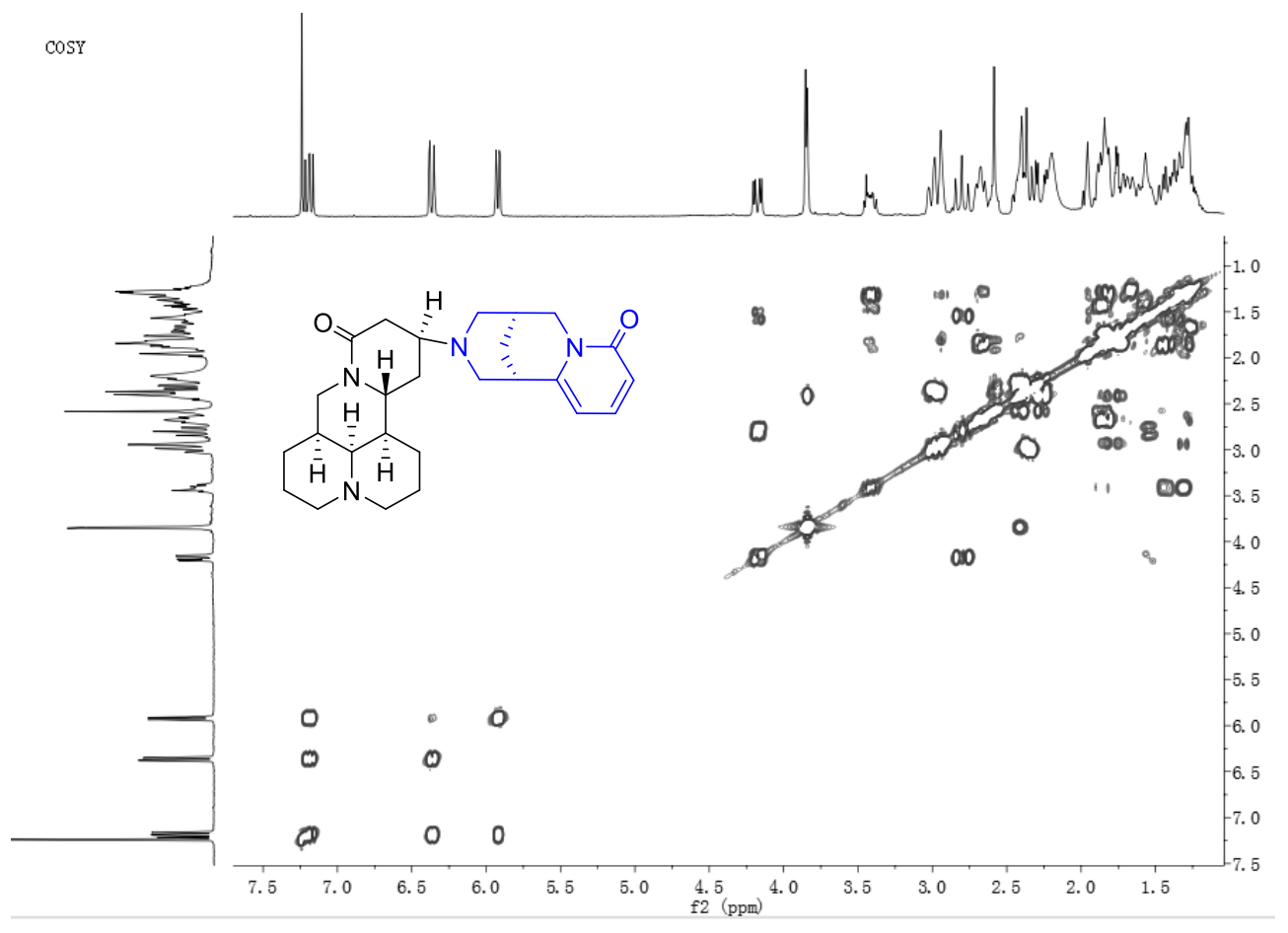

Figure S57. ${ }^{1} \mathrm{H}-{ }^{1} \mathrm{H}$ COSY spectrum of 6 in $\mathrm{CDCl}_{3}$

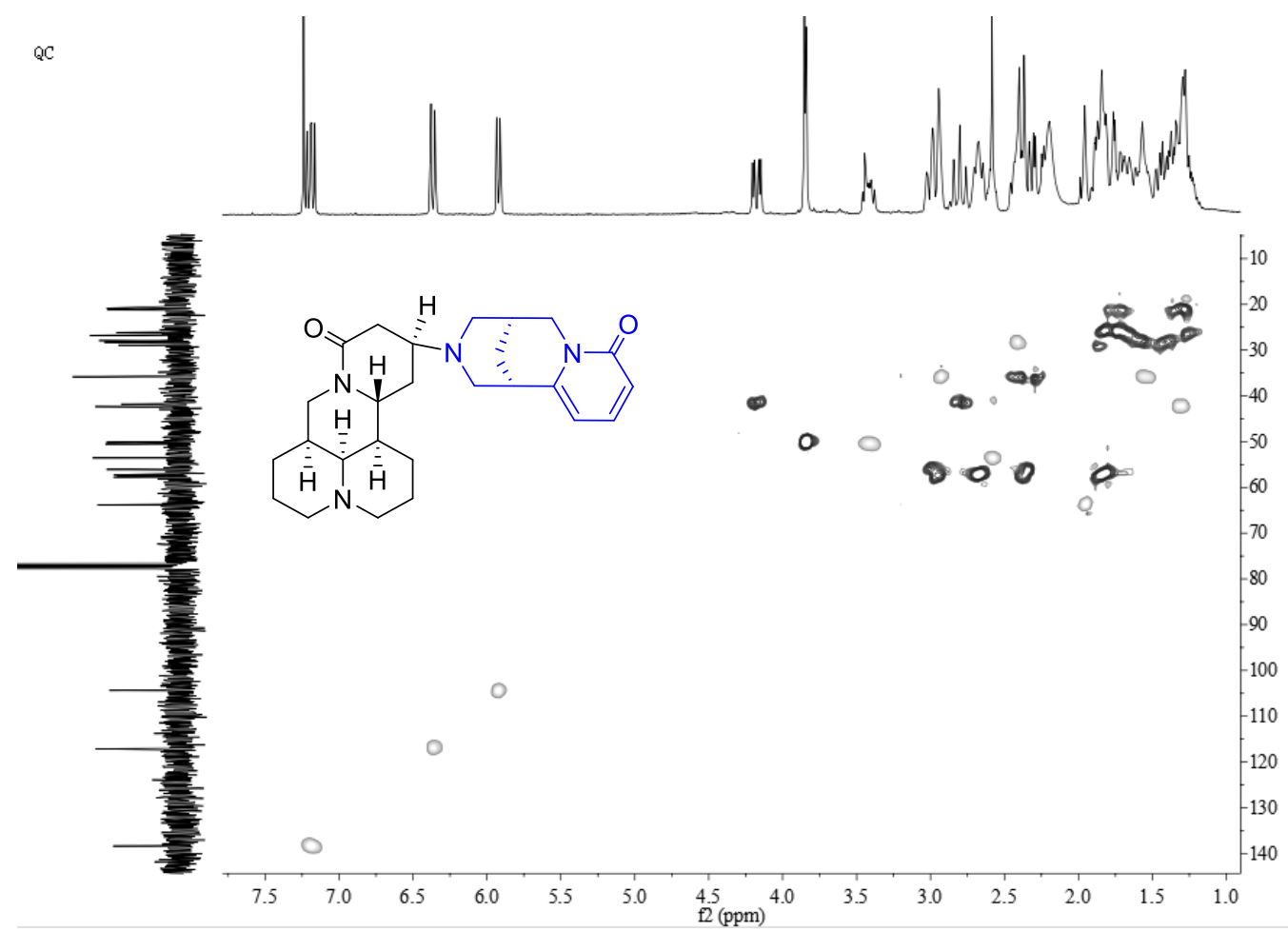

Figure S58. HSQC spectrum of 6 in $\mathrm{CDCl}_{3}$ 


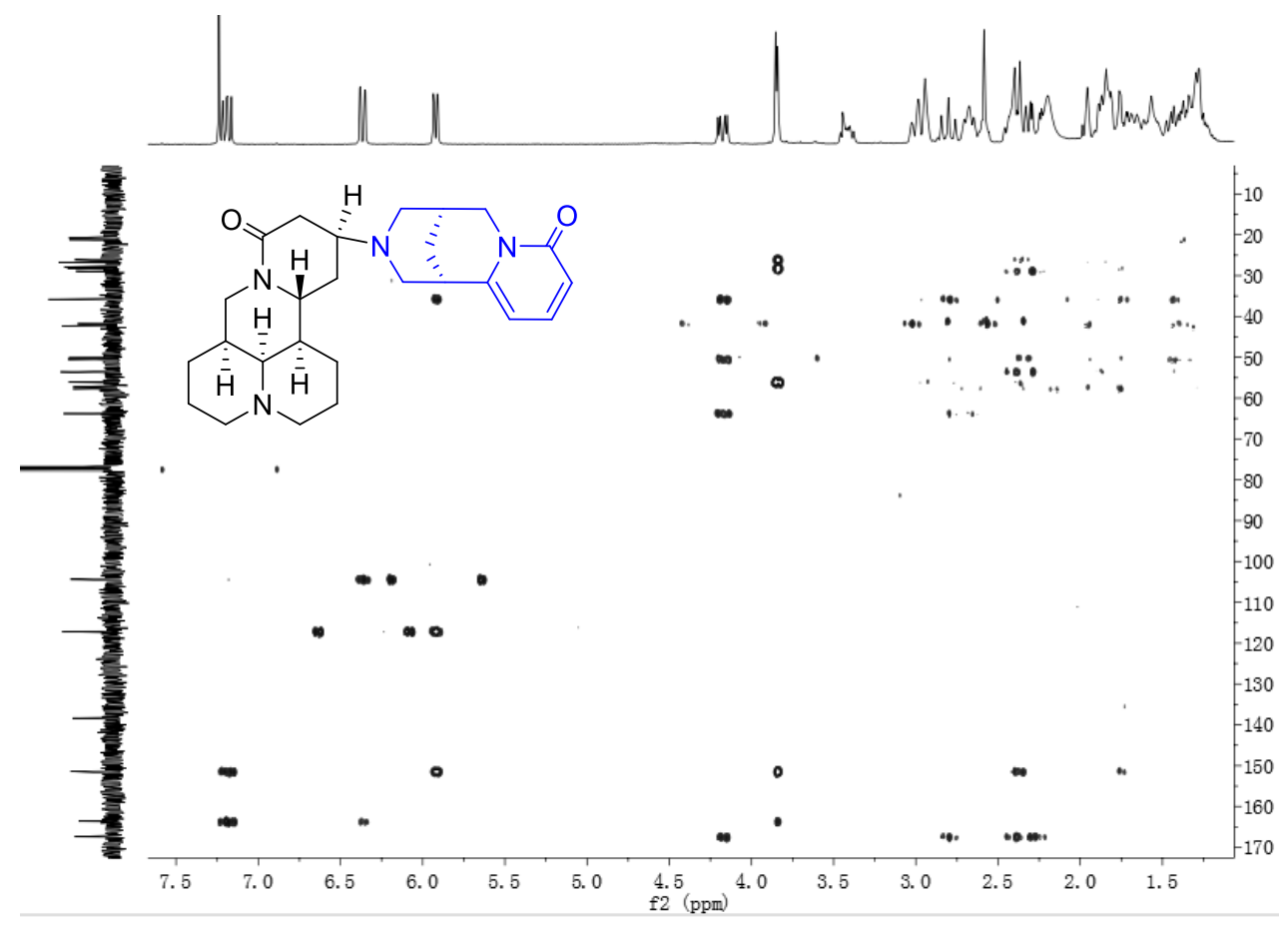

Figure S59. HMBC spectrum of 6 in $\mathrm{CDCl}_{3}$

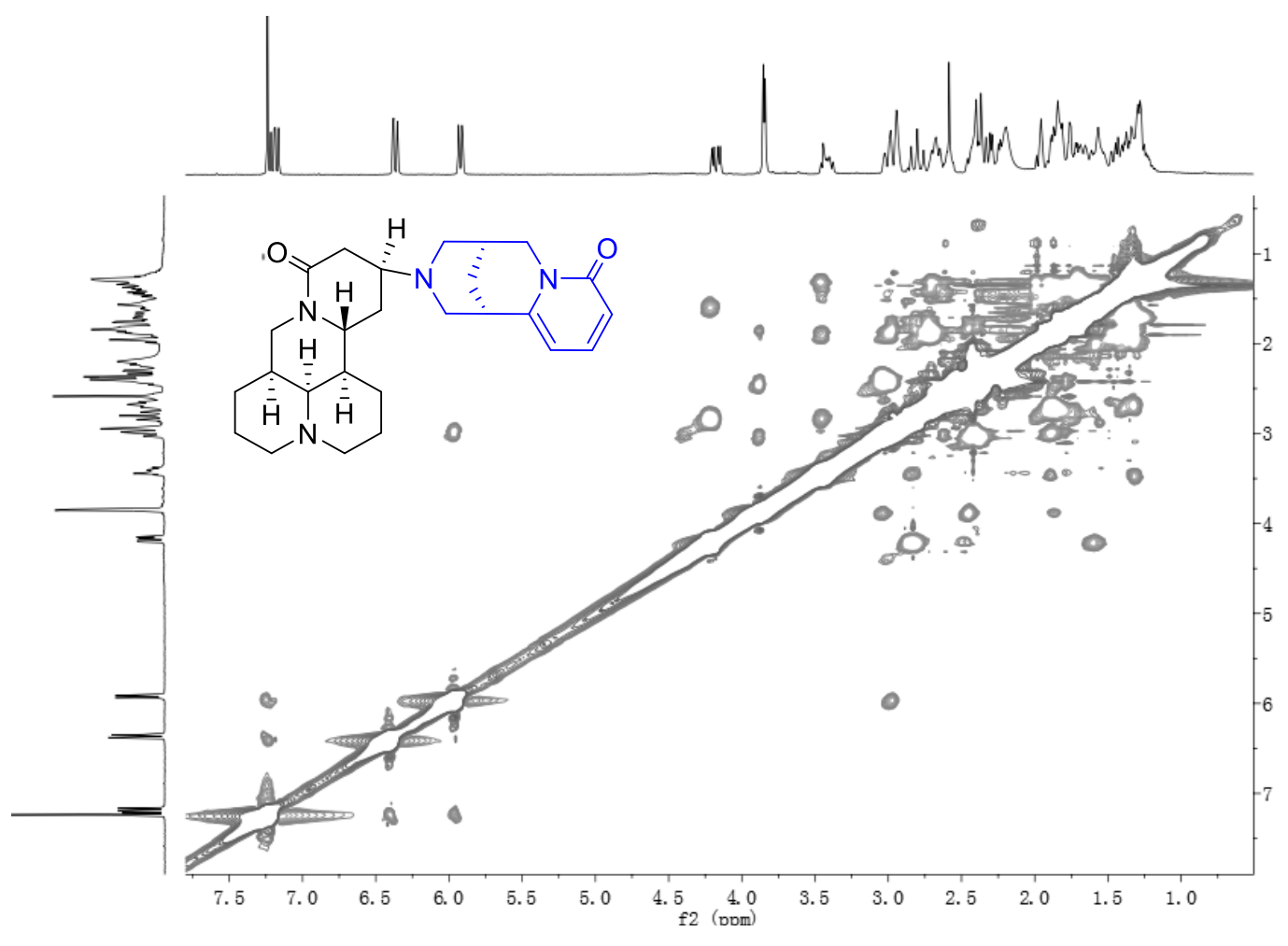

Figure S60. ROESY spectrum of 6 in $\mathrm{CDCl}_{3}$ 


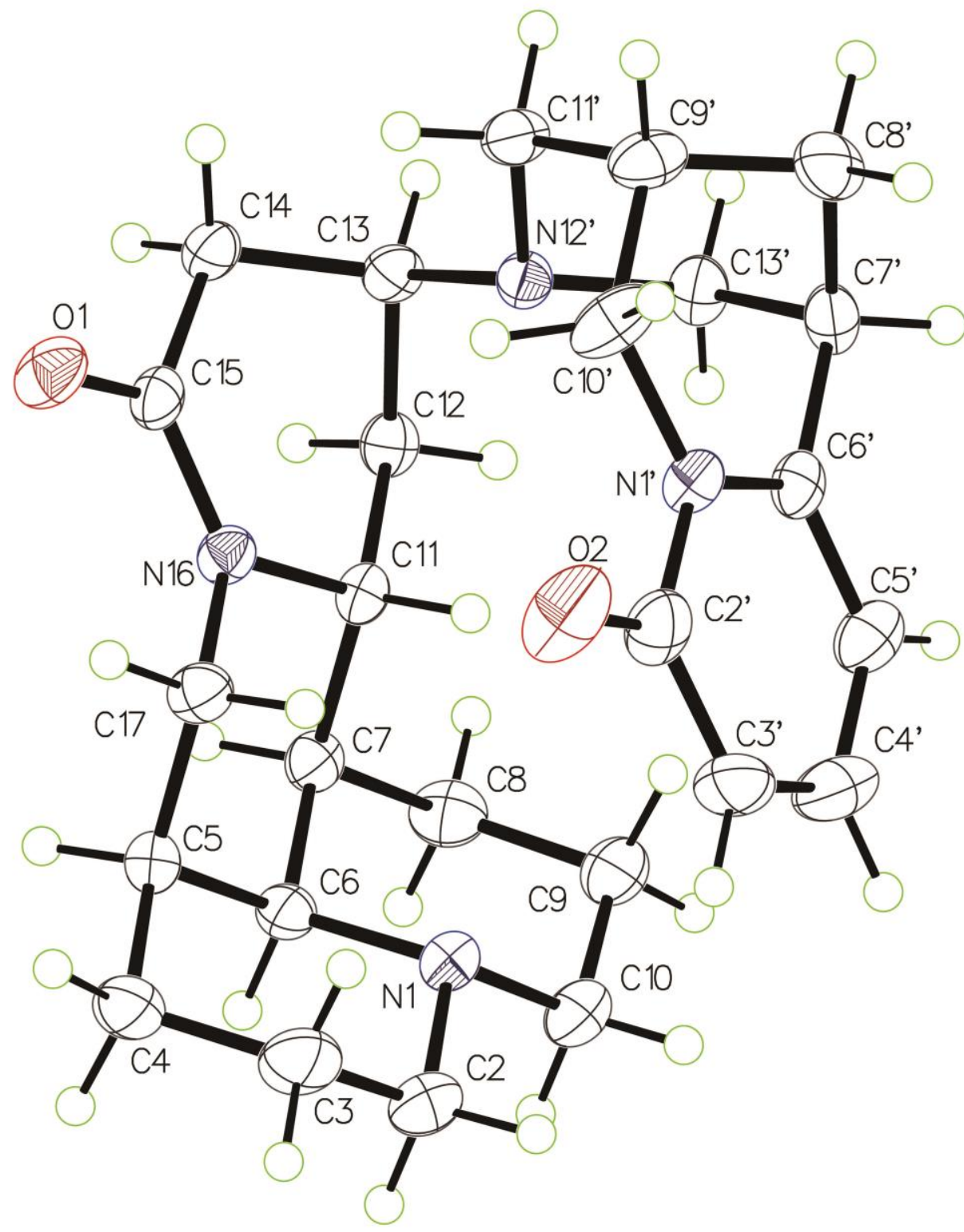

Figure S61. X-ray ORTEP drawings of 6. The thermal ellipsoids are scaled to the $50 \%$ probability level 


\section{X-ray crystallographic data of 6}

Empirical formula

Formula weight

Temperature/K

Crystal system

Space group

$a / \AA$

$b / \AA$

$c / \AA$

$\alpha /^{\circ}$

$\beta /^{\circ}$

$\gamma /{ }^{\circ}$

Volume $/ \AA^{3}$

Z

$\rho_{\text {calc }} \mathrm{g} / \mathrm{cm}^{3}$

$\mu / \mathrm{mm}^{-1}$

$F(000)$

Crystal size/ $/ \mathrm{mm}^{3}$

Radiation

$2 \Theta$ range for data collection $/^{\circ}$

Index ranges

Reflections collected

Independent reflections

Data/restraints/parameters

Goodness-of-fit on $\mathrm{F}^{2}$

Final R indexes $[\mathrm{I}>=2 \sigma(\mathrm{I})]$

Final $\mathrm{R}$ indexes [all data]

Largest diff. peak/hole / e $\AA^{-3}$

Hooft parameter

Flack parameter
$\mathrm{C}_{26} \mathrm{H}_{38} \mathrm{~N}_{4} \mathrm{O}_{2}$

438.60

173.01(10)

orthorhombic

$P 2{ }_{1} 2_{1} 2_{1}$

$8.96337(9)$

$13.08470(13)$

$19.0292(2)$

90.00

90.00

90.00

2231.79(4)

4

1.305

0.656

952.0

$0.3 \times 0.28 \times 0.24$

$\mathrm{CuK} \alpha(\lambda=1.54184)$

8.2 to 125.46

$-10 \leq \mathrm{h} \leq 8,-14 \leq \mathrm{k} \leq 15,-21 \leq 1 \leq 21$

18129

$3576\left[\mathrm{R}_{\text {int }}=0.0262, \mathrm{R}_{\text {sigma }}=0.0172\right]$

$3576 / 0 / 289$

1.084

$\mathrm{R}_{1}=0.0303, \mathrm{wR}_{2}=0.0810$

$\mathrm{R}_{1}=0.0308, \mathrm{wR}_{2}=0.0814$

$0.14 /-0.45$

$-0.05(7)$

$0.0(2)$ 


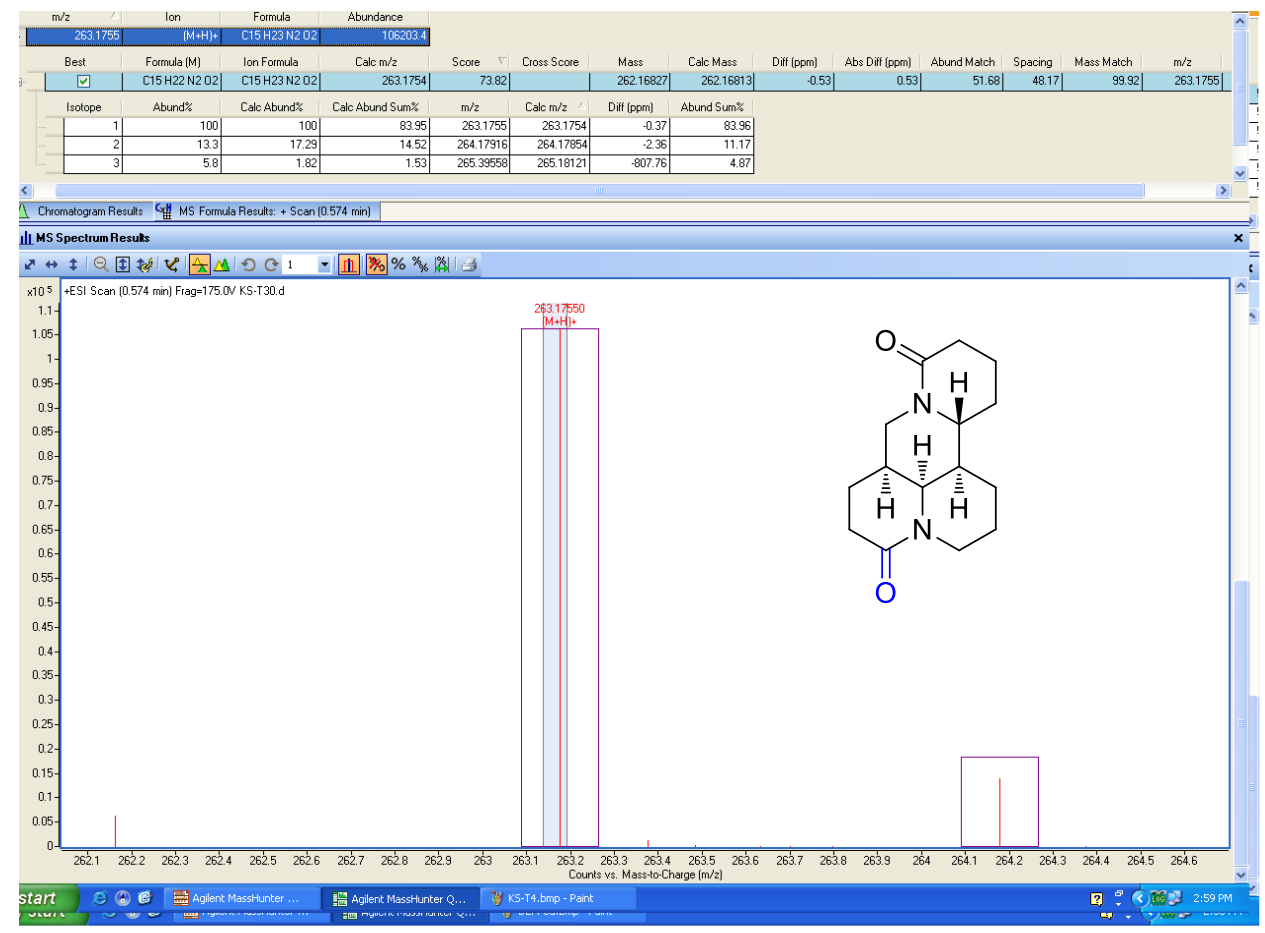

Figure S62. HR-ESI-MS spectrum of 7

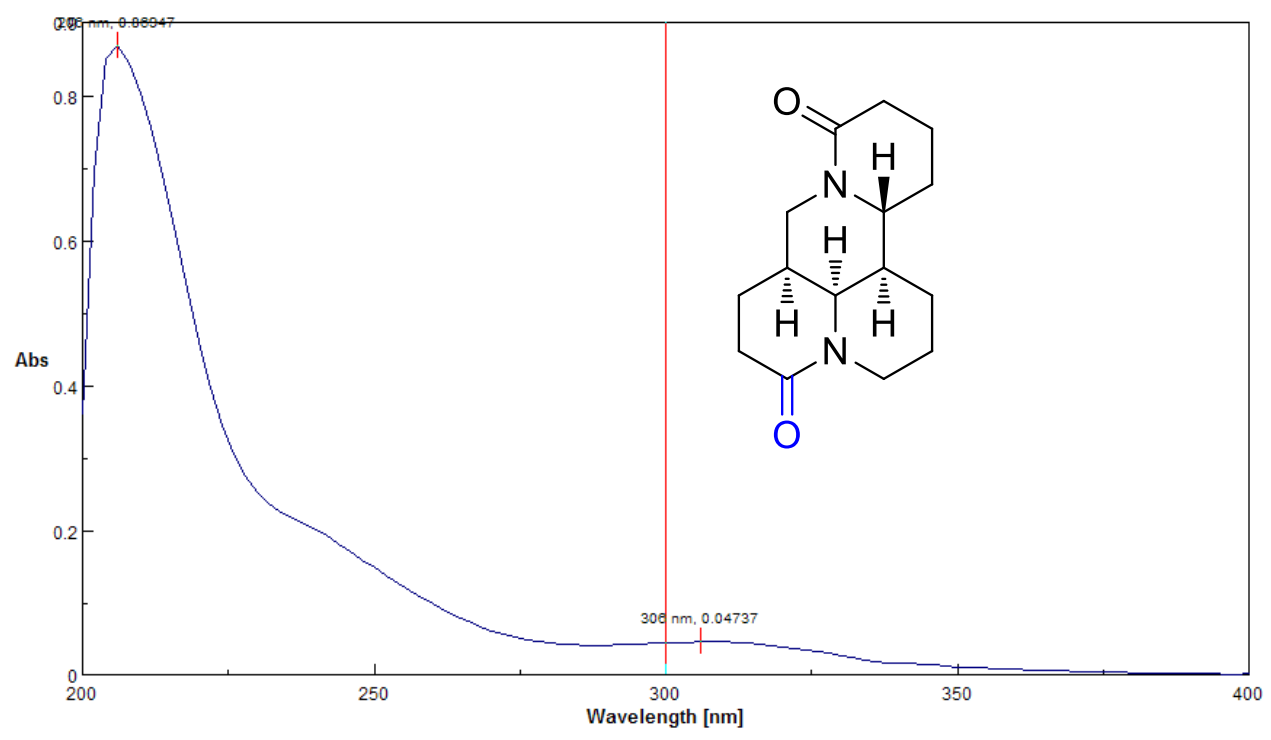

Figure S63. UV spectrum of $7\left(\mathrm{CH}_{3} \mathrm{OH}\right)$ 


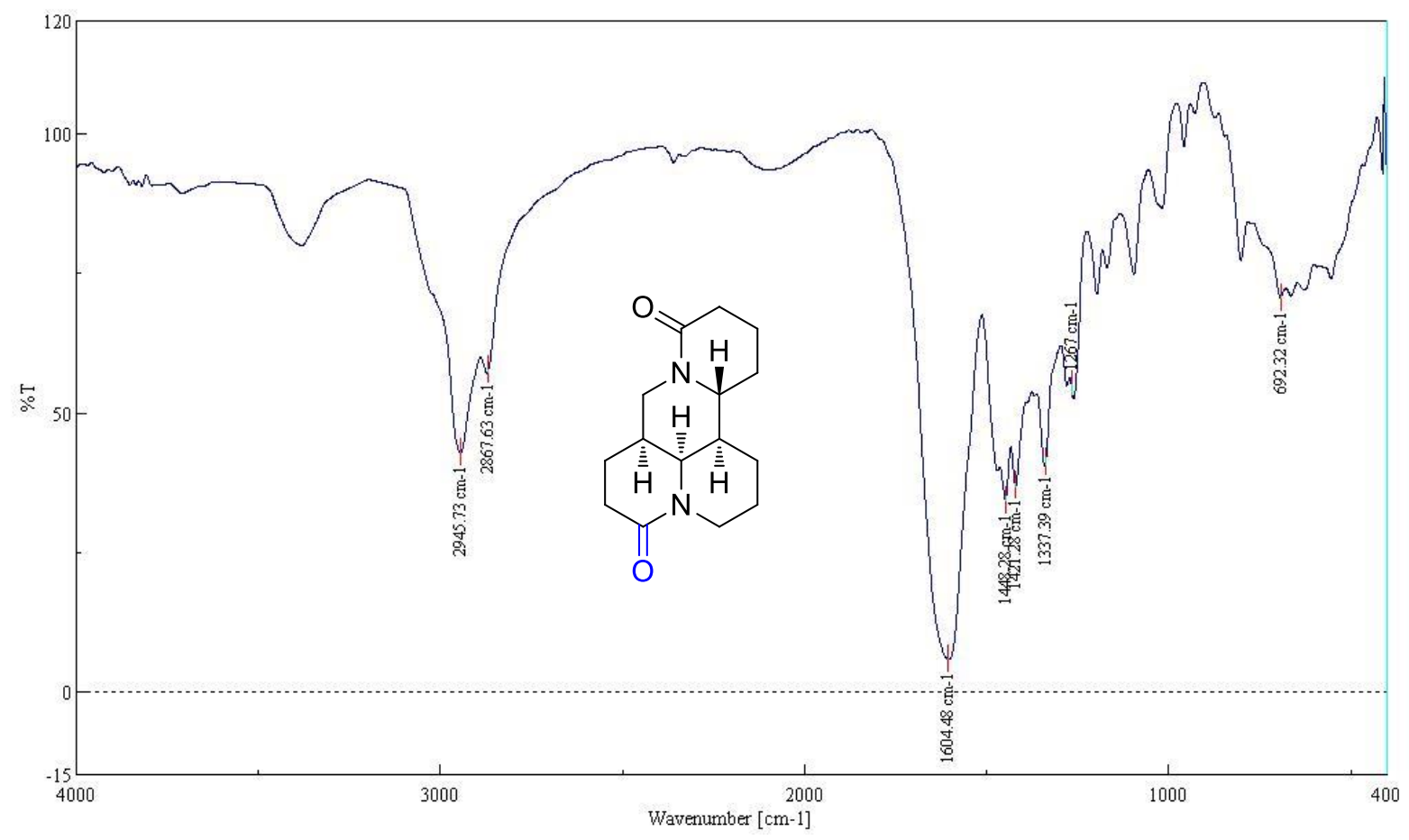

Figure S64. IR spectrum of 7 (KBr disc)

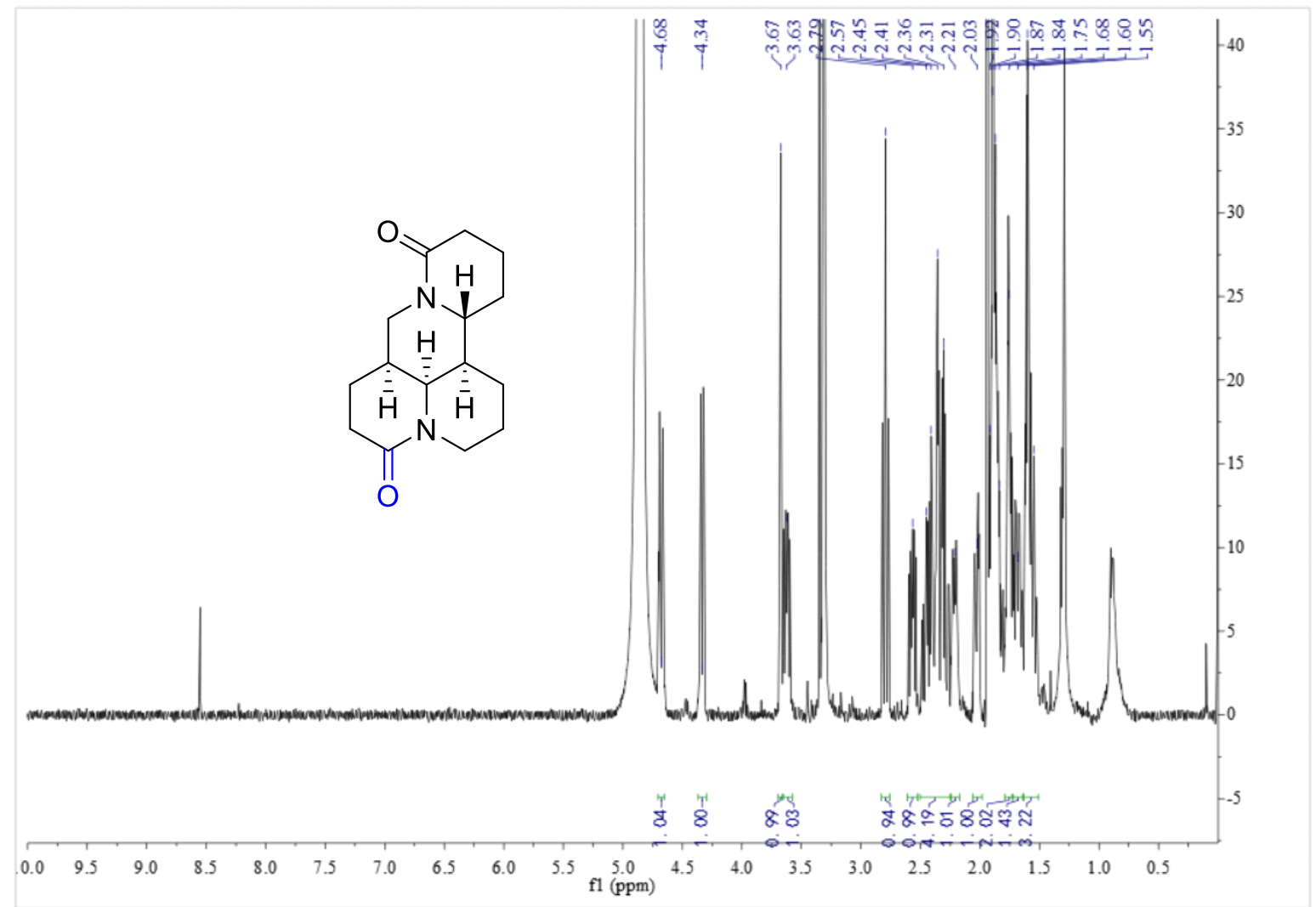

Figure S65. ${ }^{1} \mathrm{H}$ NMR spectrum of 7 in $\mathrm{CD}_{3} \mathrm{OD}$ 


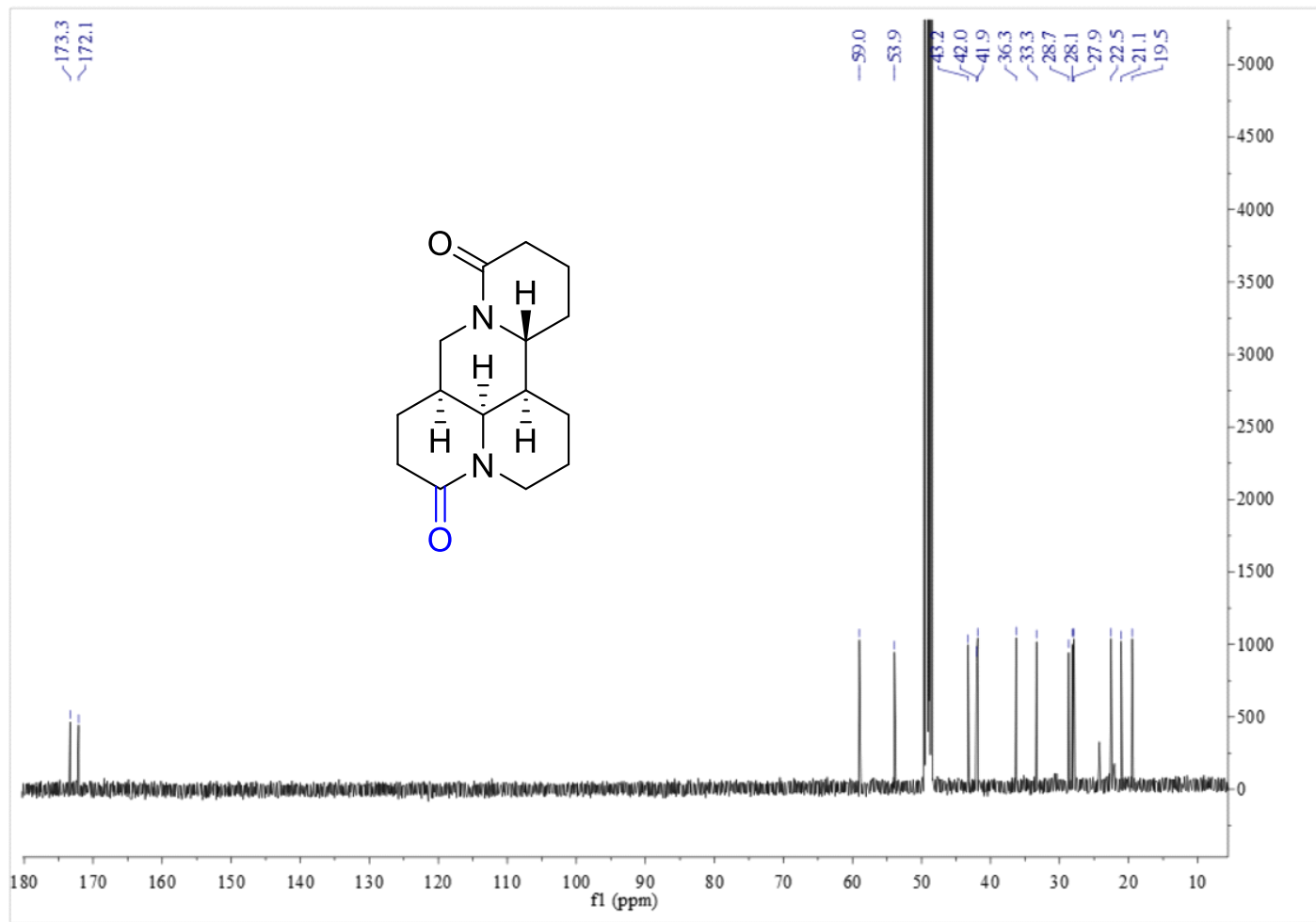

Figure S66. ${ }^{13} \mathrm{C}$ NMR spectrum of 7 in $\mathrm{CD}_{3} \mathrm{OD}$

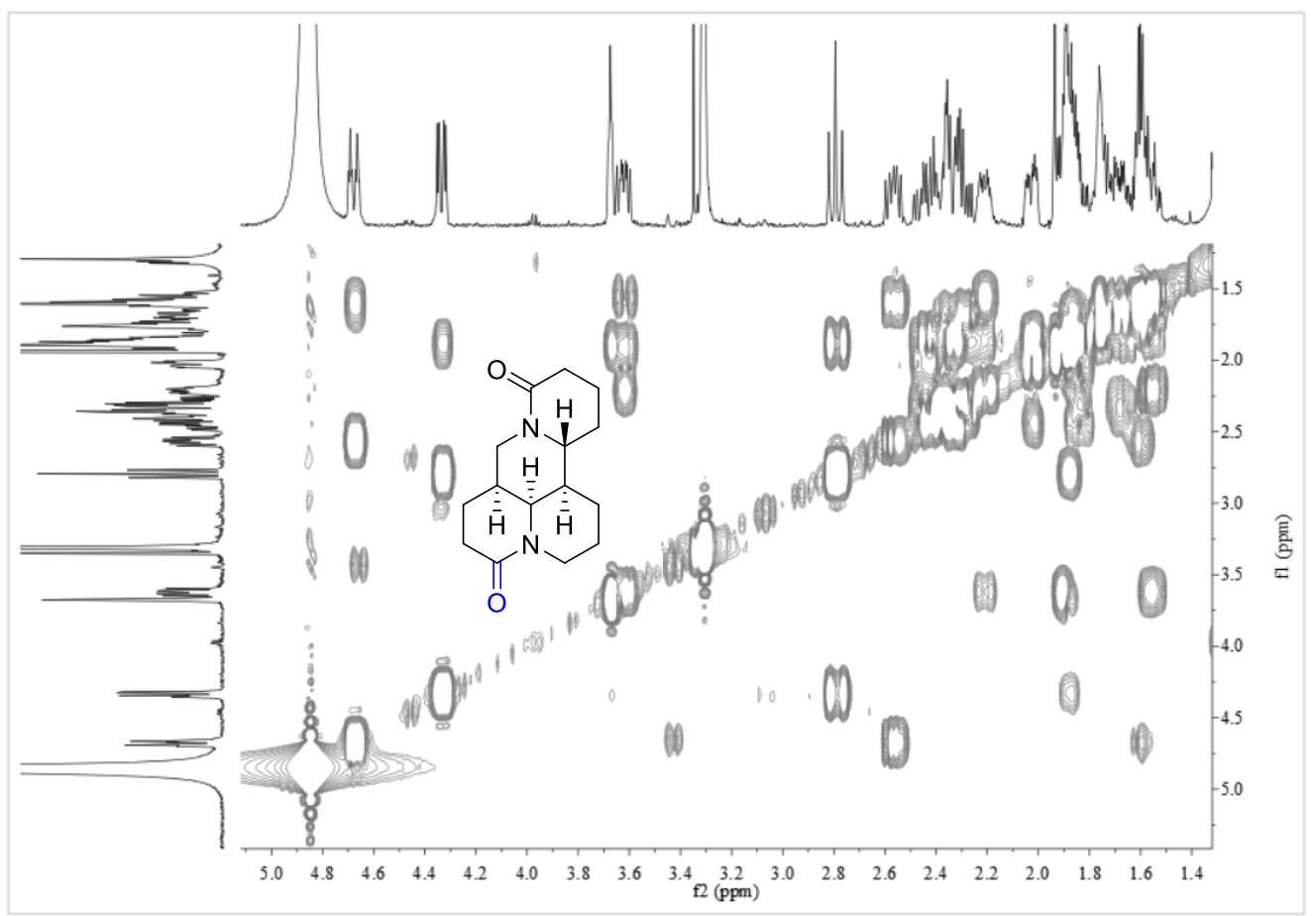

Figure S67. ${ }^{1} \mathrm{H}-{ }^{1} \mathrm{H}$ COSY spectrum of 7 in $\mathrm{CD}_{3} \mathrm{OD}$ 


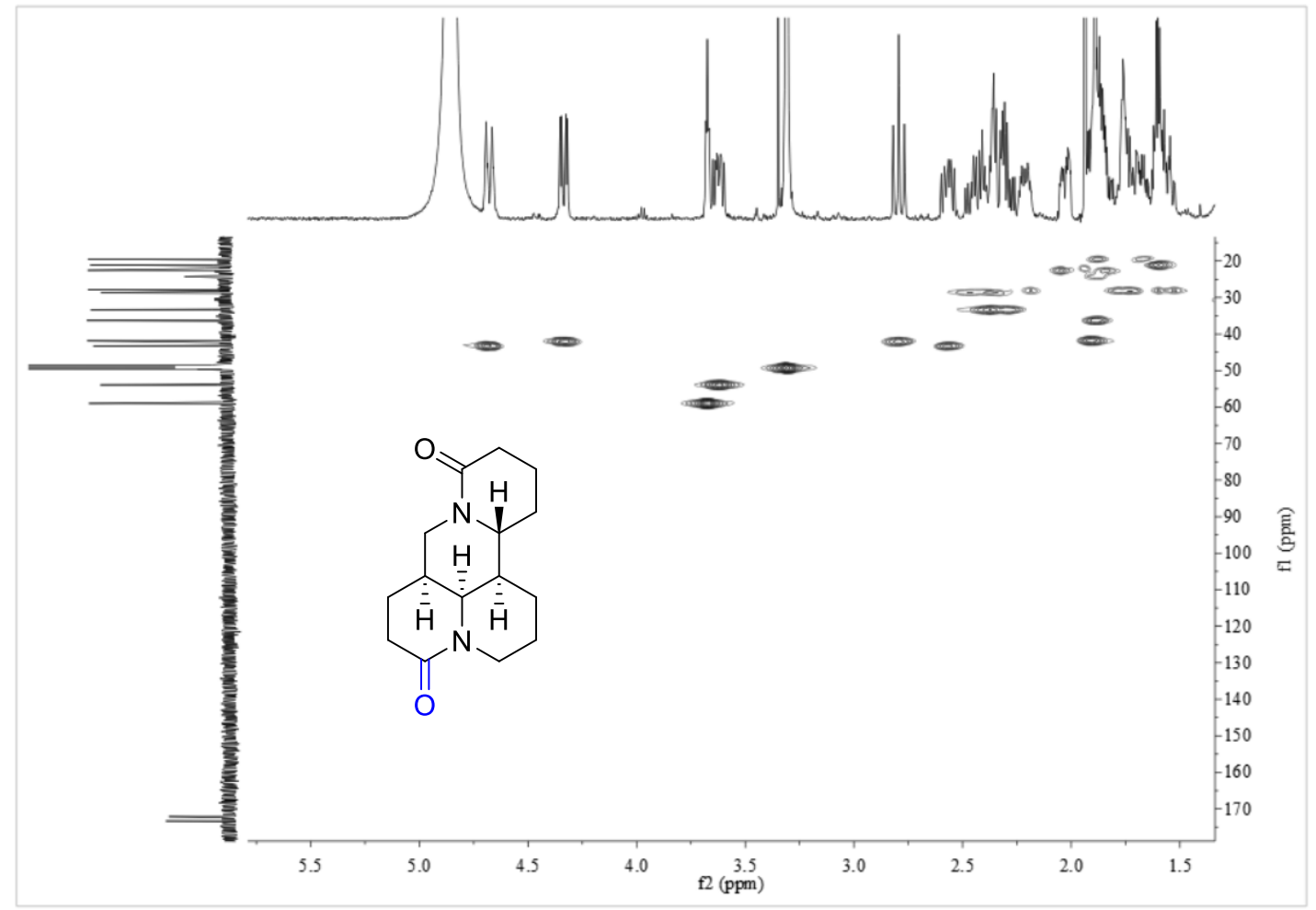

Figure S68. HSQC spectrum of 7 in $\mathrm{CD}_{3} \mathrm{OD}$

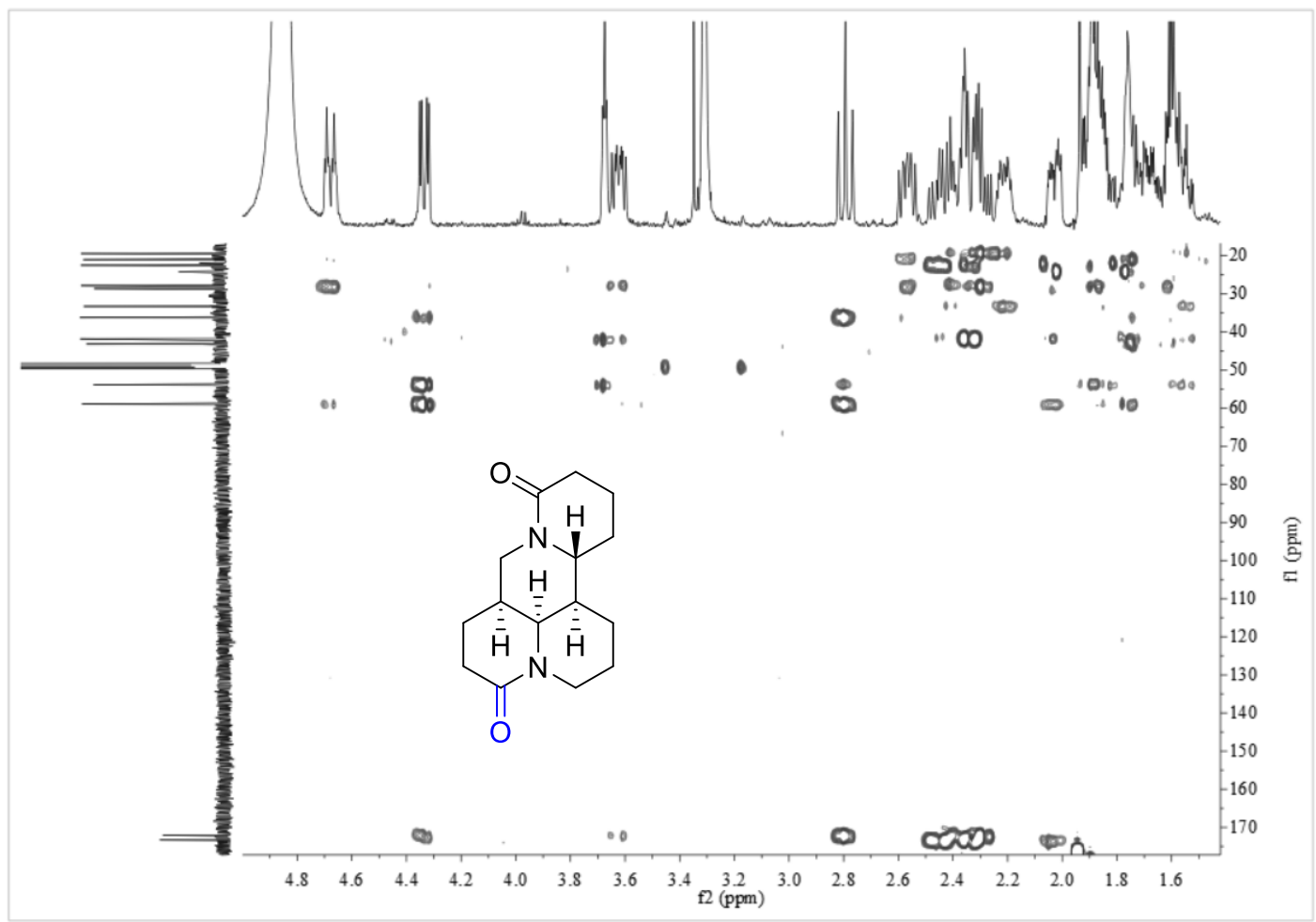

Figure $\mathrm{S69}$. $\mathrm{HMBC}$ spectrum of 7 in $\mathrm{CD}_{3} \mathrm{OD}$ 


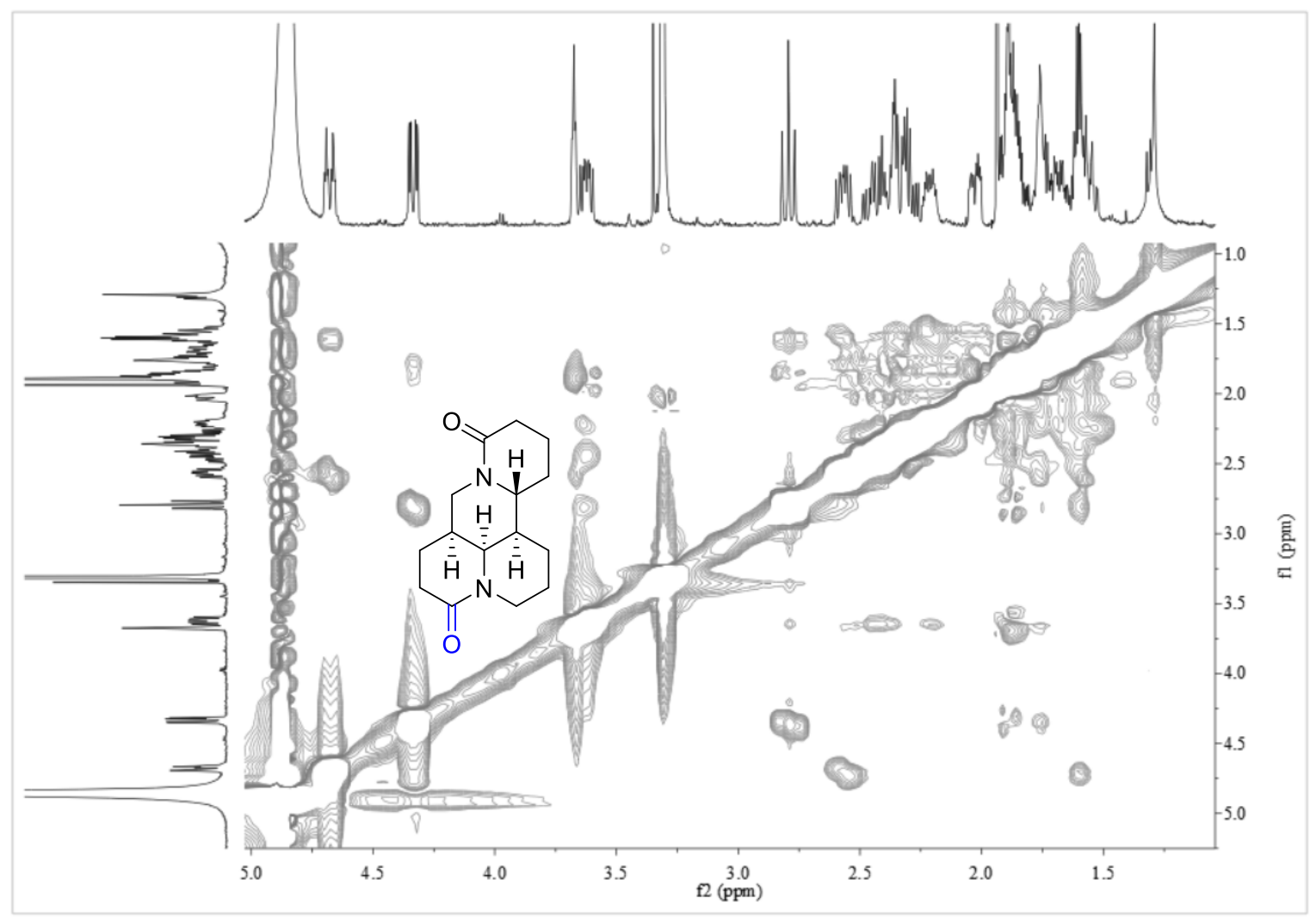

Figure S70. ROESY spectrum of 7 in $\mathrm{CD}_{3} \mathrm{OD}$

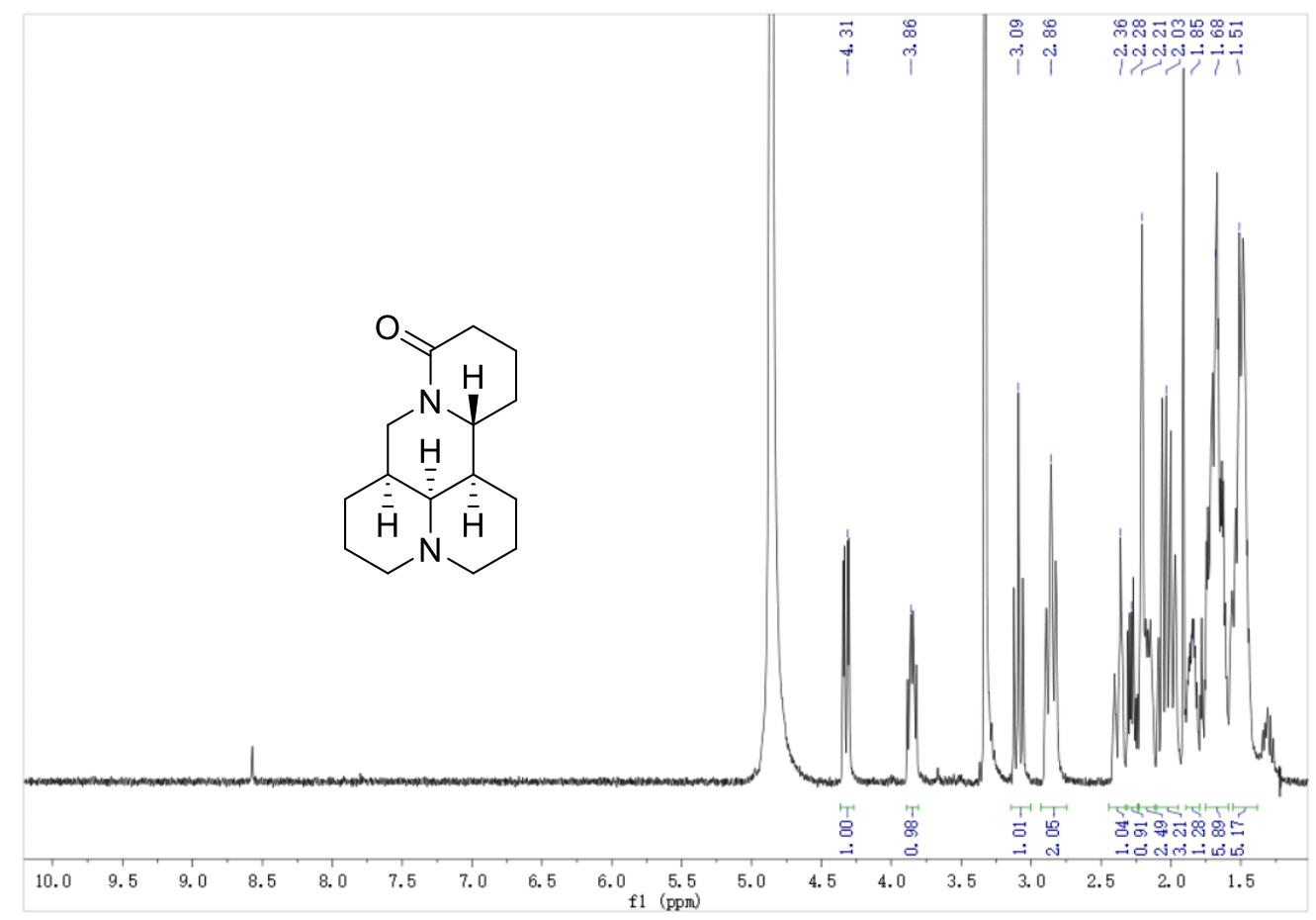

Figure S71. ${ }^{1} \mathrm{H}$ NMR spectrum of 8 in $\mathrm{CD}_{3} \mathrm{OD}$ 


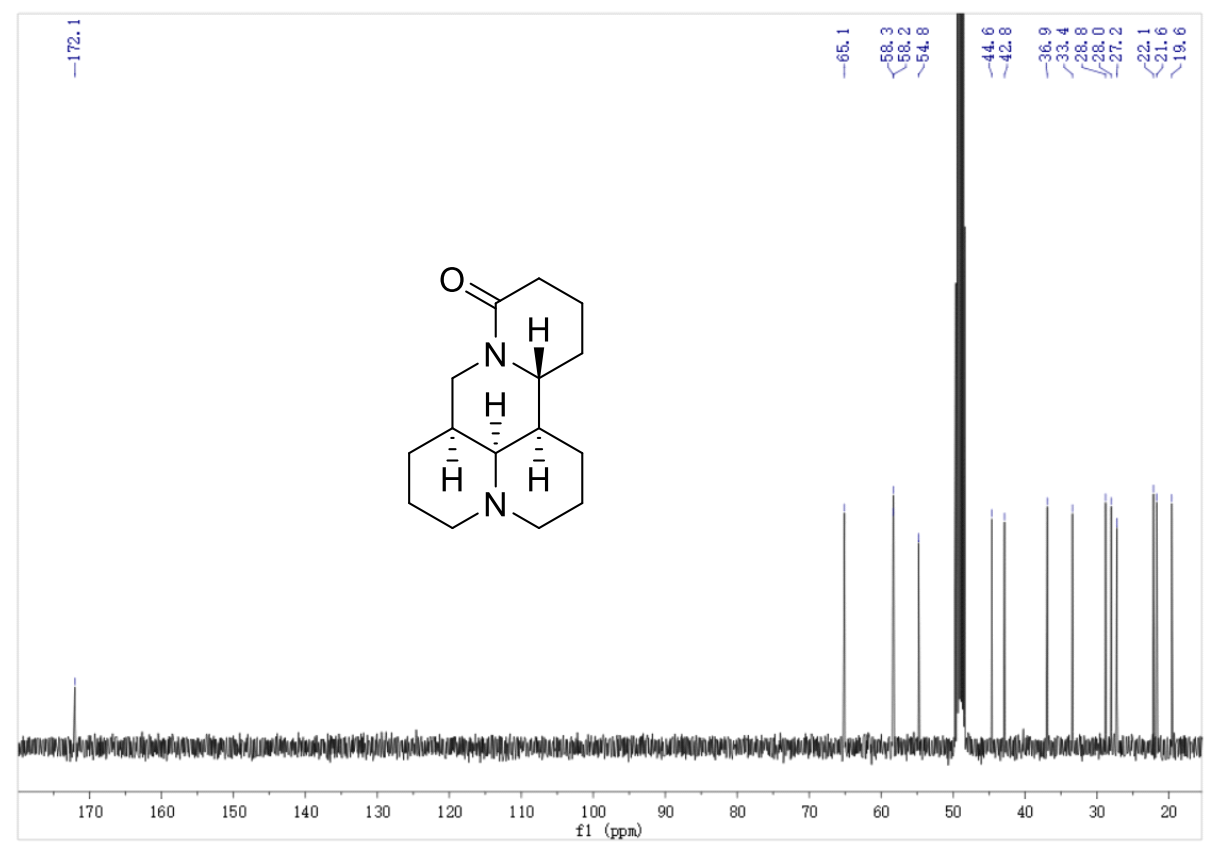

Figure $\mathrm{S72} .{ }^{13} \mathrm{C}$ NMR spectrum of 8 in $\mathrm{CD}_{3} \mathrm{OD}$

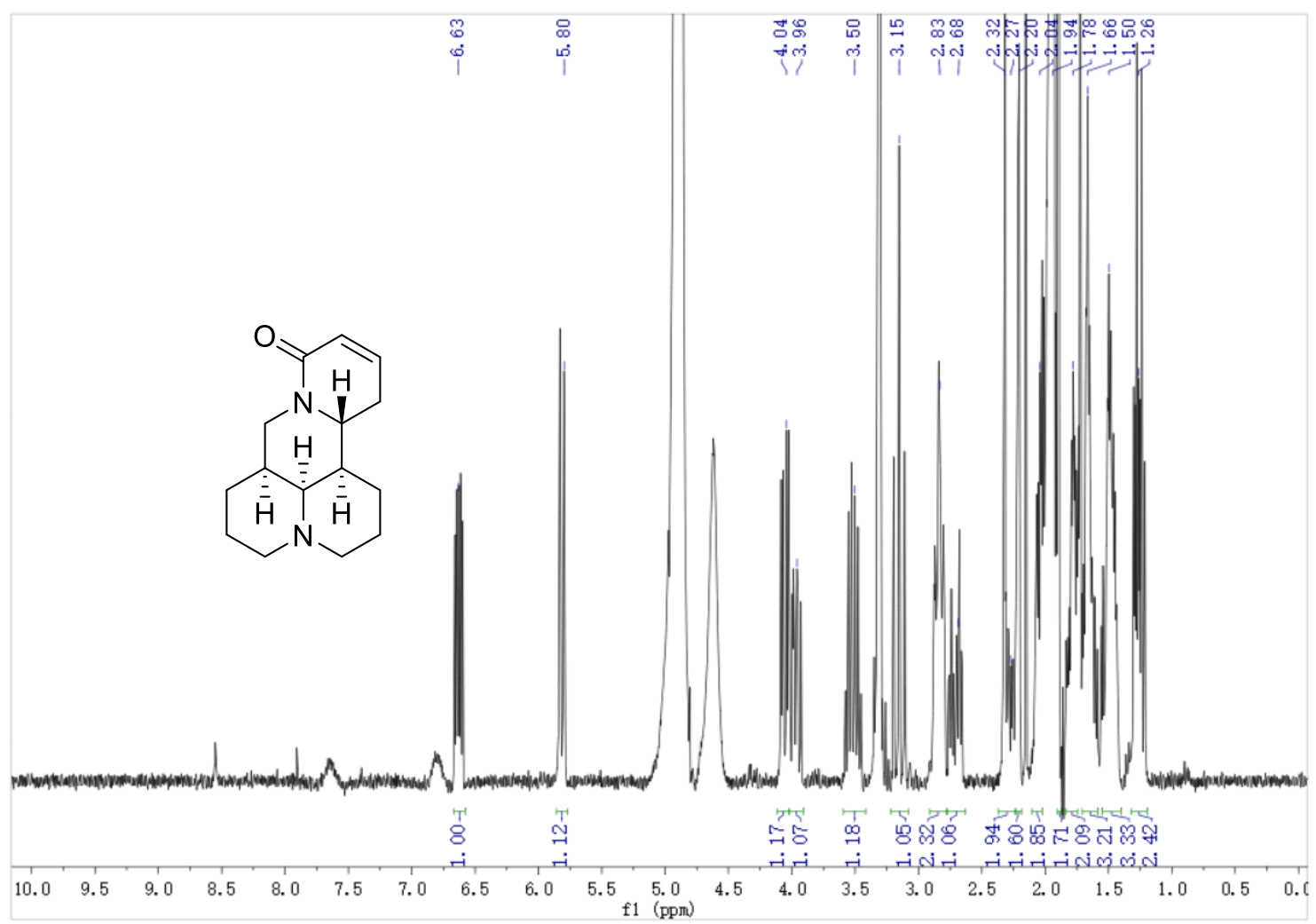

Figure S73. ${ }^{1} \mathrm{H}$ NMR spectrum of 9 in $\mathrm{CD}_{3} \mathrm{OD}$ 


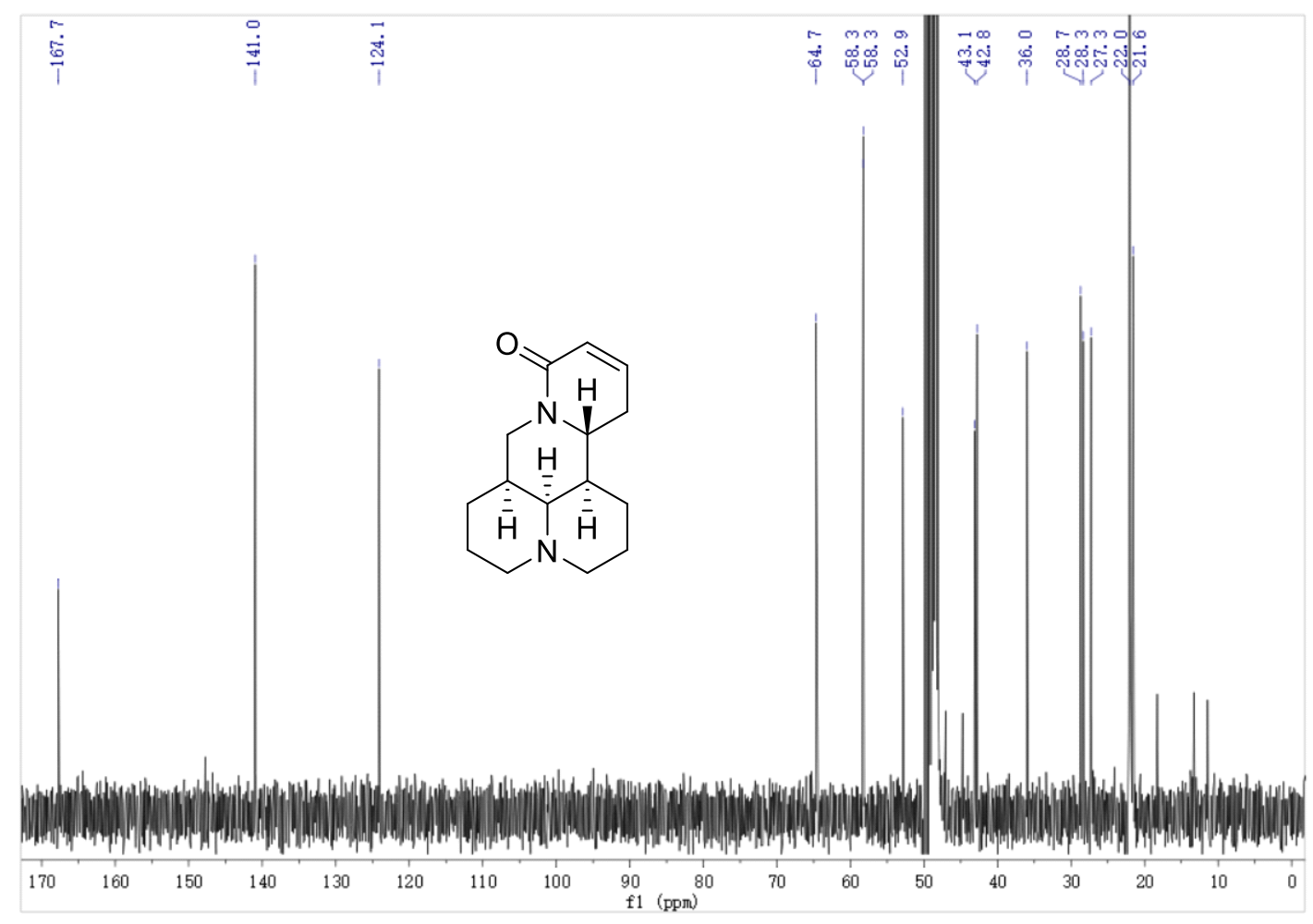

Figure S74. ${ }^{13} \mathrm{C}$ NMR spectrum of 9 in $\mathrm{CD}_{3} \mathrm{OD}$
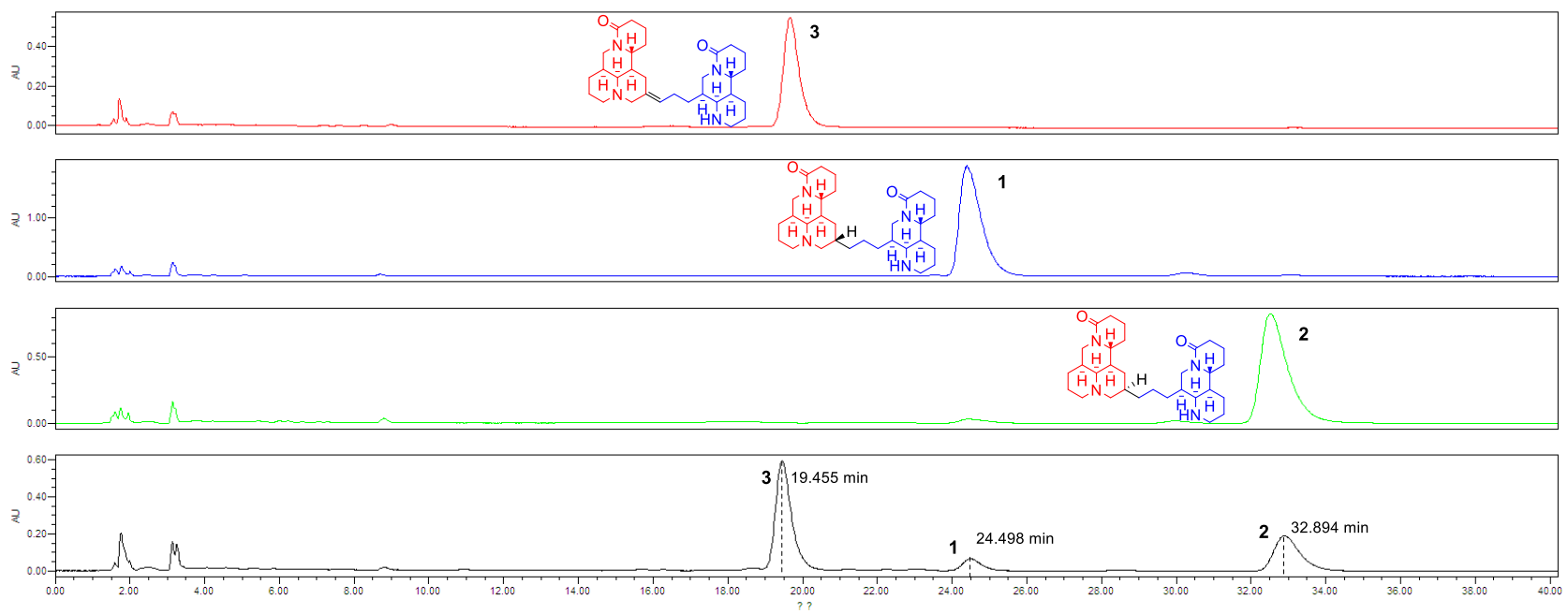

Figure S75. HPLC chromatogram of the reaction mixture of 3 

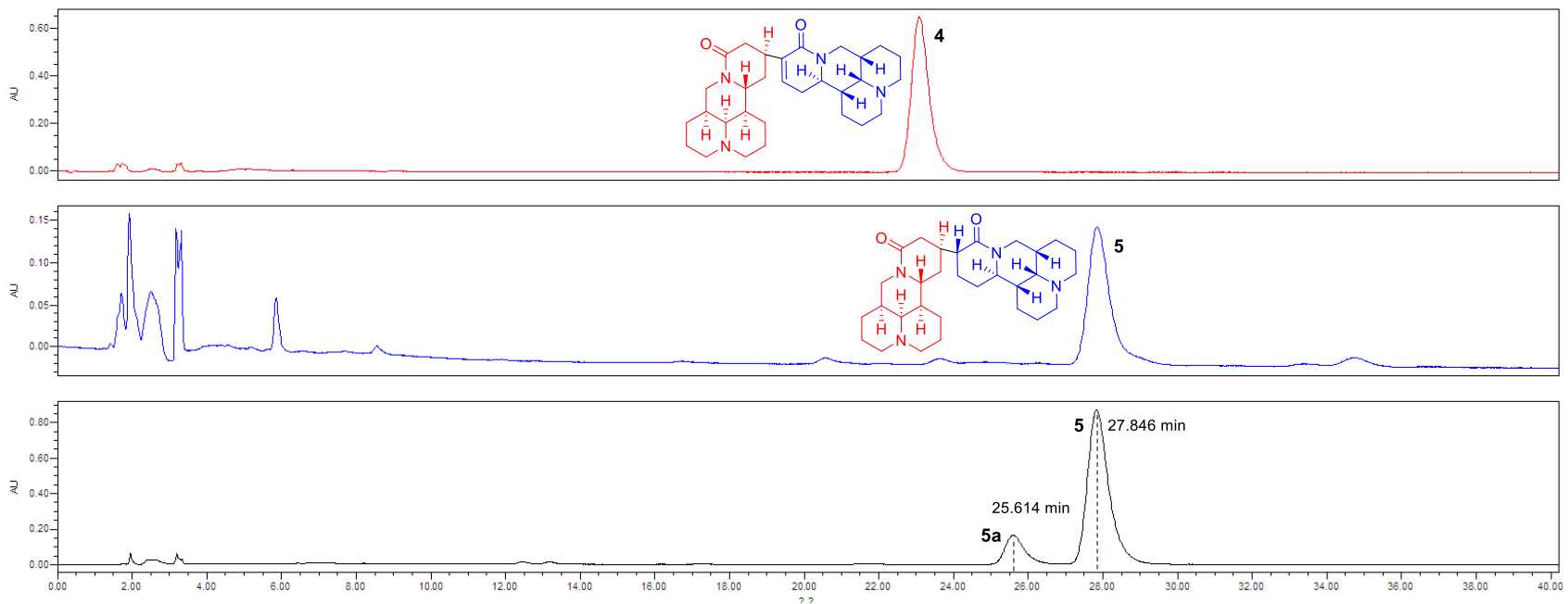

Figure S76. HPLC chromatogram of the reaction mixture of 4 